University of Louisville

ThinkIR: The University of Louisville's Institutional Repository

Electronic Theses and Dissertations

$12-2004$

\title{
Some social considerations in the female portraits of Palma Vecchio.
}

Sarah Elizabeth Fruehling 1977-

University of Louisville

Follow this and additional works at: https://ir.library.louisville.edu/etd

\section{Recommended Citation}

Fruehling, Sarah Elizabeth 1977-, "Some social considerations in the female portraits of Palma Vecchio." (2004). Electronic Theses and Dissertations. Paper 466.

https://doi.org/10.18297/etd/466

This Master's Thesis is brought to you for free and open access by ThinkIR: The University of Louisville's Institutional Repository. It has been accepted for inclusion in Electronic Theses and Dissertations by an authorized administrator of ThinkIR: The University of Louisville's Institutional Repository. This title appears here courtesy of the author, who has retained all other copyrights. For more information, please contact thinkir@louisville.edu. 
SOME SOCIAL CONSIDERATIONS IN THE FEMALE PORTRAITS OF PALMA VECCHIO

By

Sarah Elizabeth Fruehling

B.A., Mount Vernon Nazarene College, 2000

\begin{abstract}
A Thesis
Submitted to the Faculty of the Graduate School of the University of Louisville in partial Fulfillment of the Requirements for the Degree of
\end{abstract}

Master of Arts

Department of Art History

University of Louisville

Louisville, Kentucky

December 2004 
SOME SOCIAL CONSIDERATIONS IN THE FEMALE PORTRAITS OF PALMA VECCHIO

\author{
By \\ Sarah Elizabeth Fruehling \\ B.A., Mount Vernon Nazarene College, 2000
}

A Thesis Approved on

December 3, 2004

by the following Thesis Committee:

Thesis Director 


\section{DEDICATION}

This thesis is dedicated to my parents

Rev. and Mrs. Robert \& Paula Fruehling.

With your enduring love and support I have accomplished many things. Without it, I would have never endeavored to take this journey. 


\section{ACKNOWLEDGMENTS}

I would like to thank my professor, advisor, and thesis director Dr. Christopher Fulton, who has seen me through this journey to its fruition. Thank you for your patience and guidance, Dr. Fulton. To my family and friends I owe many thanks for the support and love given through the tough times and the long nights. Thank you to the members of my family and friends in Ohio and California: Mom and Dad, Brother Andy, Grandma Riley, Uncle Byron and Aunt Laura, Uncle Doug., Tim and Karen Jensen and Trisha Grose. To my wonderful friends who reside in Louisville, Kentucky: Tom and Wendy Doyon, Jennifer Gruber, Dayne Gardner, Flint Collins, Blair Arsenaux, and Donna Moros. I would also like to thank my wonderfully caring and colorful neighbors, Dawn Muncie, Steve Burton, and Bridget Dattilo, and to Samuel J. Kat who is my constant companion and friend. 


\section{ABSTRACT \\ SOME SOCIAL CONSIDERATIONS IN THE FEMALE PORTRAITS OF PALMA VECCHIO}

Sarah E. Fruehling

December 3, 2004

This thesis is an investigation into the world of sixteenth-century Venice, encompassing a group of female portraits by artist Palma Vecchio. I utilized many primary and secondary sources concerning Renaissance society, including several which discussed the roles of women during the Renaissance.

This thesis is divided into four chapters that discuss the purpose and evolution of the female portrait, ideal poetic beauty, and the authority the courtesan carried in both the poetry and the painting in Venice.

Chapter one covers a short history of the portrait as well as an investigation of how the female portrait evolved from the profile image to the frontal three-quarter image. It also discusses how Palma Vecchio would have adhered to the early concepts of the portrait, yet came to depict women in a idealized fashion that came to be the Renaissance Venetian artist's specialty. Chapter two explores the issue of poetic beauty upon the paintings of Palma Vecchio and its birth from the Humanist movement, as started by the fourteenth-century poet Petrarch. Chapter three discusses the role of the courtesan predominately in Venice. An educated and sophisticated woman who sold sexual favors, performed a considerable role in the world of the female portrait in Venice, particularly the images by Palma Vecchio. Chapter four, the conclusion, concretizes the issues of 
ideal poetic feminine beauty, the courtesan in female portraiture, and how these two factors carried an enormous role not only in the female portraits of Palma Vecchio, but in the social fabric of Venice. 


\section{TABLE OF CONTENTS}

PAGE

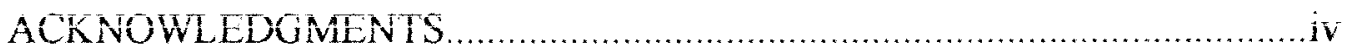

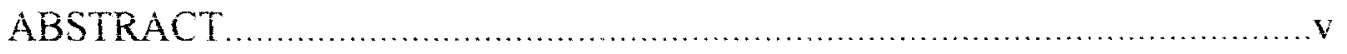

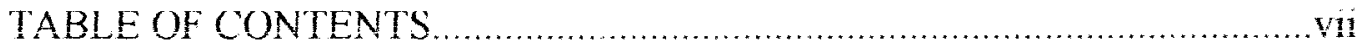

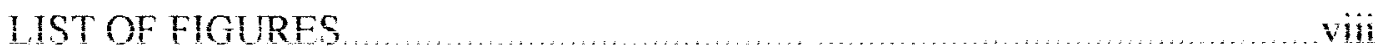

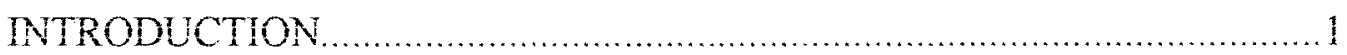

CIAPTER I

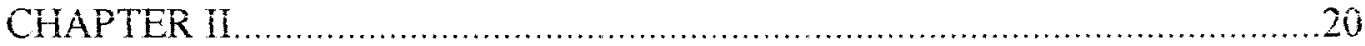

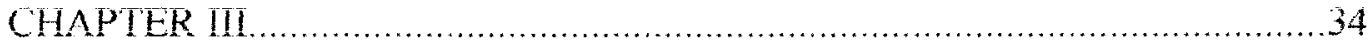

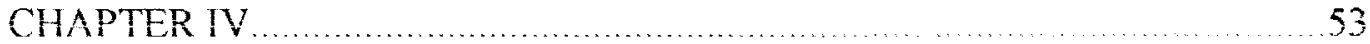

MAGES

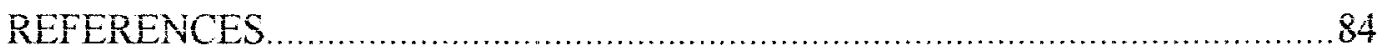

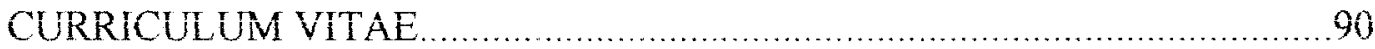




\section{I.IST OF FIGURES}

FIGURES

PAGE

1. Palma Vecchio. Portrait of a Woman Called 'La Bella', 1518-20. Oil on Canvas, $90 \times 80 \mathrm{~cm}$. Lugano-Castagnola Collection, Thyssen Bomenisza

2. Palma Vecchio. Portrait of a Woman in Profile, c. 1520-25. Oil on

Canvas, $49 \times 42.4 \mathrm{~cm}$. Kunsthistorisches Museum, Vienna. .55

3. Domenico Ghirlandaio. Portrait of Giovanna degli Alhizzi

Tornábuoni, c. 1488-90. Tempera on panel, $77 \times 49 \mathrm{~cm}$. Museo

Thyssen-Bornemisza, Madrid. 56

4. Leonardo da Vinci. Portrait of Ginevra de Benci, 1474-78.

Oil on panel, $38.1 \times 37 \mathrm{~cm}$. National Gallery of Art, Washington, D.C. 57

5. Leonardo da Vinci. Portrait of Cecilia Gallerani (Lady with Ermine), 1489-90. Oil on panel. Krakow, Princes Czartoryski Foundation.

6. Titian. Portrait of a Woman Called la Bella, 1536. Oil on canvas.

Galleria Pitti, Florence

7. Palma Vecchio. Portrait of a Woman Called Violante, 1516-18.

Oil on canvas, $64.5 \times 50.8 \mathrm{~cm}$. Kunsthistorisches Museum, Vienna. 60

8. Palma Vecchio. Portrait of a Woman in Blue, 1512-14.

Oil on canvas, $63.5 \times 51 \mathrm{~cm}$. Kunsthistorisches Museum, Vienna.

9. Tullio Lombardo. Portrait Bust of a Woman, 1520. Marble.

Private Collection.

10. Bronzino. Portrait of Laura Battiferri, 1558. Oil on panel, $83 \times 60 \mathrm{~cm}$. Palazzo Vecchio, Florence

11. Raphael. Detail from Galatea, c. 1518. Fresco, Villa Farnesina, Rome. 
12. Palma Vecchio Portrait of a Woman Called Flora, 1522-24.

Oil on panel, $77 \times 64 \mathrm{~cm}$. National Gallery, London.

13. Titian. Portrat of a Woman Called Flora, c. 1516-18.

Oil on canvas. Gallerie degli Uffizi, Florence. 66

14. Paris Bordon. Portrait of a Woman Called Flora, 16th century.

Oil on canvas, $103 \times 85 \mathrm{~cm}$. Musee du Louvre, Paris

15. Veronese. Leda and the Swan, 16th century. Oil on canvas. 68

16. Marcantonio Raimondi. Leda and the Swan, 1520. Engraving, .69

17. Titian. Danae and the Golden Shower, c. 1545. Oil on canvas, Prado Museum, Madrid. 70

18. Giulio di Antonio Bonasone. Dunae, 1545. Engraving. .71

19. Giorgione. Sleeping Vemus (Dresden Venus), 1510. Oil on panel, Staatliche Gemaldegalerie, Dresden.

20. Titian. Venus of Urbino, 1538. Oil on panel, Gallery degli Uffizi, Florence .73

21. Bernardino Licinio. Reclining Venus, 16th century, Temporarily at the Palazzo Vecchio, Florence. 74

22. Tintoretto. Portrait of Veronica Franco, c. 1575. Oil on canvas, Worcester Art Museum, Worcester, Massachusetts. 75

23. Palma Vecchio. Portrait of a Woman With a Bared Breast, 1524-26.

Oil on panel, $79.1 \times 62.2 \mathrm{~cm}$. Gemaldegalerie, Berlin (Dahlem). .76

24. Raphael. La Fornarina, c. 1515. Oil on canvas, $34 " \times 25.5 \%$. Palazzo Barbarini, Rome. .77

25. Palma Vecchio(Titian). Portrait of a Woman in Black, 1510.

Oil on panel, $59.5 \times 44.5 \mathrm{~cm}$. Kunsthistorisches Museum, Vienna 78

26. Palma Vecchio. Portrait of a Woman Called 'La Cortigiana', 1524-26. Oil on canvas, $87.4 \times 73.5 \mathrm{~cm}$. Museo Poldi-Pezzoli, Madrid. .79 


\section{INTRODUCTION}

The female portrait in the Italian Renaissance in the sixteenth century journeyed to a realm that dramatically changed the ant of fenale portraiture. Palma Vecchio, an artist who lived in Venice most of his life, adhered to the Venetian school of painting. He belonged to the artistic circle of the legendary painter 'Titian, as well as other great painters such as Paris Bordone and Sebastiano del Piombo. Within Palmas oeuvre are a group of approximately twenty surviving paintings which depict unnamed female beauties. Quickly deemed as portraits of courtesans by many art historians, I believe these paintings reveal the story of a culture in Venice which revolved around the poetry, the female portrait and the beautiful woman.

In this paper I will address a number of issues concerning not just the female portraits of Palma Vecchio, but the underlying motives behind the brush work. Why were women depicted in such a fashion, that they appeared in either the state of utmost virtue, or was scantily clad, allowing herself to be ogled by a male audience? The answers to this question involves poetry of the sixteenth century, which brought the ideals of feminine beauty into light, which was then illustrated in paint. The courtesan, the living, breathing personification of such ideals, could be considered muse of the painting and poetry. This then developed into a portrait prototype commonly seen in the Venetian school of painting.

The portrait in the beginning of the Renaissance was for posthumous 
commemoration, and usually served to immortalize men in bronze or marble. The female profile portrait served a similar purpose, but was a tool used by nobile families wishing to marry their daughters, while extending their familial lineage and power through the Italian countryside. Credit for the evolution of the female profile portrait into a frontal image is given to Leonardo da Vinci, who in his Portrait of Ginevra de Benci, presented a frontal image of a woman who interacts with the viewer, beckoning a conversation. With this composition, the ground work for any future female portrait was laid, opening an enormous door to a genre which would become a mainstay in western culture.

Poetic ideals of feminine beauty resounding in the artist's minds were a motivating factor in most female portraits. Poets and writers such as Agnolo Firenzuola, Giangiorgio Trissino, and Federingo Luigini fueled the beliefs that a woman of unsurpassing beauty and virtue could be depicted on the canvas, and existed for their viewing pleasure. Palma Vecchio's female portraits are a prime example of such poetic liscense. With their alabaster skin, golden hair, and vermillion lips, the ladies gaze intensely at the viewer, acknowledging that no distance nor time could keep her from returning the gaze. This granted the viewer the ability to seek solace in the image.

The courtesan, who is often viewed as the sitter in Palma's portraits, lived an autonomous existence apart from the societal rules for women. Educated, beautiful, and elegant, she ruled the hearts and bank accounts of many of the male elite in Venice. Her existence and success is due in part to the role she played within the artistic world in Venice. Through her involvement in a patriarchal society, the courtesan lived in a culture which was part of her own doing. It was a culture which was supported by her enigmatic qualities as a woman who fulfilled the fantasies of men on the canvas, and in the bedroom. A coension of elements exist within the female portraits by Paima Vecchio. A 
large piece of the social fabric of Venice lay in the story of the female portrait, the poetic ideal of feminine beauty, and the courtesan. The following essays are an exploration of these elements and the female poriraits by Palma Vecchio fit the caiegory. 


\section{CHAPTER ! \\ THE FEMALE PORTRAIT IN THE ITALIAN RENAISSANCE}

Leonardo da Vinci once said concerning female portraiture, that to paint a female one had the potential to charm the male beholder to such an extent that the very identity of the woman did not matter. Leonardo was living in a time in history where the men were memorialized in stone and bronze. Women too were depicted in portraiture, but not in the same fashion, nor with the same intention in mind. The story of the portrait began as a practical function in the commemoration of men after death. While this continued to be a primary function of the portrait during the fiftenth and sixtecnth centuries, it appears that ulterior motives crept in concerning the female portrait.

Palma Vecchio, a Venetian painter and contemporary of Titian and Paris Bordone, executed a group of female portraits that have puzzled art historians for years. Two of these paintings, Porirait of a Woman called la Bella and Portrait of a Woman in Profite, (Figs. 1,2) are among a group of nearly twenty surviving paintings. Palma's intentions were far more complicated than simply depicting beautiful women for the sake of portraiture and commemoration. Many art historians have claimed that the women sitting

da Vinci, L., Leonardo on Paiming, an Anhology of Wriungs by Leonardo da Vimed wh a Selection of bocuments relaing to His Career as an Artist. Martin Kemp, ed., Yale Unversity Press, New Haven, 1989. 26 . 
for the portraits were simply courtesans or common prostitutes. ${ }^{2}$ Nevertheless, within these two paintings lie numerous influences of portraiture from the fifteenth-century. Palma Vecchio followed the provocative route of the Veneitan arist. He depicted creatures on the canvas that could bewitch the male viewer to the point of obsession. Palma intended to depict what many poets at the time of the Venerian Renaissance attempted to describe through verse which is ideal feminine beauty.

John Pope Hennessey states in his book The Porirain m the Renassance, that the initial role of the portrait was a commemorative one. The portrait was directed towards the future when the living would no longer be alive. ${ }^{3}$ Fundamental to this was the making of proper records of the human face. An example of this is the death mask. A functional tool, the death mask was necessary for large commemorative functions such as the commemoratve bust medal of lllippo Brunclesch." Berger suggests the family anchive essentialy included a commemorative icon, such as the death mast, whoh was linked to the Early Modern portrait." He interprets the portrait as "an ched of the painter's vision of the soul and an interpretation of the formal and archival evidence of the sitter The pottait was an epitome of the sitte's character, as it was manifested by the family archive. Berger sideas are a more modern interpretation which deal with the relationship between the sitter and the artist. Although it is a modern interpretation of the function of the portrait Berger may be correct. But according to other scholars, portraiture involved a

\footnotetext{
Rylands P Palma lecho Cambridge lniverity Press Cambridge, 1092 89. Rylands makes a comment stating that some of Pama's blondes are intended to sexualy arousing. I would insist that wh of Palna's blondes in the groups of pantings at hand, still in existence, were intended to be sexulity arousing. Patricia Fonini Brown also insinuates that the images by Palma under examination attests to the fact that the ambiguity of the images lends to the assumption that courtesans were the sitters

${ }^{3}$ Pope Hemessey, J. The Portrait in the Renaissatk, Pantheon, New York, 1963, 8.

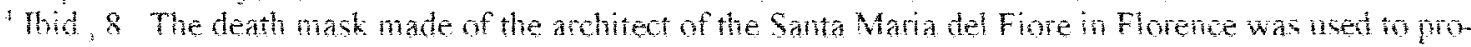
duce the commemorative medallion of Bunellesch. It wow hangs on the exterio of the Florence Cathedial.

"Berger, H.. "Fictions of the Pose: Facing the Gaze of Early Modern Portaiture". Represematons, 46. 109400

- mid 89
} 
complex social transaction between the artist, the sitter and the spectator. People did not simply sit for portraits in the Renaissance. The artist's job was to find a proper balance between iruth and hattery and to render a credible likeness, while salistying the pairon's expectations of a pleasing appearance. It is safe to say that the primary function of the portrait was to record the sitter's activity, statis, or behavior. In the display culture of Renaissance Italy, these portraits signified wealth and importance of lineage."

Yet further discussion about the birth of the portrait by Pope-Hennessey leads to the proclamation that the portrait cxpresses the rowakening of human interest in human motives and character. It is the story of how the eyes ceased to be linear symbols and became light possessing and perceiving organs we possess." It is intriguing that PopeHennessey should consider the eyes a powerful component in the function of the portrait. In the later years of the Renaissance, the gaze in Renaissance portrature evolved into an object which held a distinct amount of power over the viewer in the portrat, particularly in the female portrait

Patricia Simons, who wrote specifically on the profile portrait and the male gaze in the Renaissance, introduced several theories on the purpose of the female profile portrait in the early Renaissance. Pope-Hennessey mentions that while the profle was not the most advantageous depiction of the sitter, it was the most flattering view. And for this reason, until the late fifteenth century, the profile was the only way in which all women were cast."

Simon's has a different view on the artifice of the female portrait. PopeHennessey describes the depiction of ladies in pontaits, such as Ghinandaio's pompht of

Brown, P.F., Art and Life in Renassame lonice. Hary N. Abrams Publishers, New york 1097, 14A.

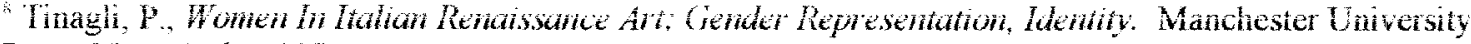
Press, New York. 1997. 47.

Ibid, 3

"Pope-Hennessey. I. The Portwat in the Renaisance, Pantheon, New York, 41 
Chorama Tomohtwoni, (Fig. 3) as possessing flaxen hair, expensive necklaces and golden hair. "Simons attests that the elements which make the image pleasing to the eye are simply descriptions of the woman's essential beauly. They are highlights of her ability to be a good wife, and a showcase for her family's wealth. The artist produced a wonderful depiction of the woman in profic, but to Simons, the girl in the potrait camot be simply seen as an image of a woman from the Renaissance. She should be seen as an image which was once gazed upon with great contempiation as a showcase of her virtue or as a prized piece of her family's prosperity. The importance of women in socicty was centered around her family and their roles as respectable and virtuous wives and mothers." The portraits of women were dynastic images, where family lineage was stressed

The motives behind the female profile portrait were not seen until the late twentieth century, Jahob Burkhardt, in his The (ivilization of the Renassance in laty, stated that "women stood on a footing of perfect equality with men in the Italian Renaissance since the educated woman, no less that the man, strove naturally after a characteristic and complete individuality " Burkhardt continues in stating that the "education given to women in the upper classes was essentially the same as that given to men." ${ }^{.13}$ Neither of these declarations are true for there is no adequate proof of their social equality. It is clear that the past decades did not question existing differences in men and women during the Renaissance. Therefore it is no surprise that scholars rarely saw a distinction between the depiction of men and women in fifteenth and early sixteenthcentury portraiture.

The profile portait was "painted by male artists for male patrons. They were

\footnotetext{
Pope-Hennessey. The Portrat. 45

"Tinagl, Women. 49.

"Burkhardt, J., The Civilization of the Renaissance in Italy. Middlemore London. 1960, $240,241$.
} 
objects which primarily addressed male vicwers. 14 This phenomonon is decmed as a dsplay culture. where the outward display of wealth was vial to one s social prestige and definition." A woman was an object of public display at the time or her matriage. Withm a marrage or betrothai contract, a woman was seen as a thing to be adomed. A marriage could be perfomed whout ariest present, where a level social display and an honorable degree of adomment was necessary for the persons present to participate in the so-called visual display which took place at the ritual (ie marriage) She was rarely visible within the city strects on at any public functions save weckly or daily mass One of a woman's primary roles before nariage was to be a beathu thing to look uph on the most important day of her life. She was then shut into her home to be a dutiful wite and mother.

"lo be a woman in the world is to be the object of the mate gace. To appeai in public is to be looked upon", wrote Giovani Bocaccio". The male gaze and temale portraiture are intimately linked upon closer serutiny. It is impossible to took beyond the fact that these images were made for men to look upon. The male gaze within the protile portrat exposes issues conceming the mind of the Renaissance mate. One of the issues to be exposed is that control cmanated over the fairer sex, even in the art of portrature. From the beginning of the profile pontat in Italy, one has to wonder why the figure was portrayed in such a fashon. Pope-llennessey suggests that the transition which existed between the profile and frontal portrait were contained in a long series of

\footnotetext{
Simons, "Women in Frames", 4 . Besides holding a tight grasp on who the wonen would mary. members of the ruling class in patrician 1 torence retained numerous restrictions on proper female betavior for women of their class.

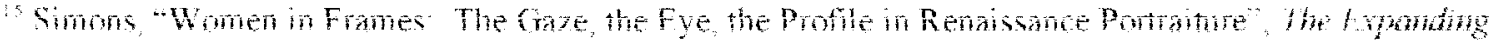

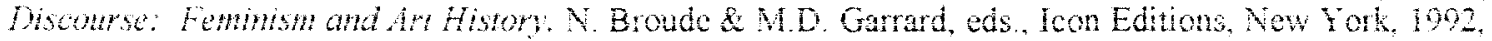
41. Display culture is indicated by the vitud display of hono, magnifcence, and weath, dements vital to one s sociat prestige and definition.

Ibid, 42

Ibid, 41, Boceacio, G. The Corbacho, Lbana, 1975.68 .
} 
cxperiments beginning with a cut sihouete. This in tum became a solid image caught momentarily in side face. The cheek, which was originally an unfamiliar terrain, was plotied sectionally on the surface of the panel. It acquired an intelligible shape in which the jaw and cheekbone are defined. ${ }^{12}$ But why were women the main subjects in most fifteenth-century profile portraits? Indeed, the issue of the gaze is a complicated one But within the Renaissance, particularly, the gaze could be seen as a metaphor for woridimess and virility making a Renaissance woman an object of public discourse who was exposed to examinations that were framed by propricty, display and "impression management"." The profle was in line with the strict social laws adhered to by the chaste and married women of Florence. Rarely permitted to walk in the city streets during the day, a noble woman was considered to be chaste, modest and possessing obeisance. She was to lower or avert her cyes in public, particularly in the presence of a man. ${ }^{20}$ Poetess Veronica Gambara wrote that she looked upon her object of "desire" and was confronted not by a man, but "waters" and a "gracious site". She narrates the plight of the noble woman of the Renaissance. ${ }^{21}$ Since she was a noblewoman, she could not look a man fully in the face. ${ }^{22}$ Sermons from San Bernardino who addressed women from his pulpit to "Bury your eyes" follow the strict social confines a proper woman faced in sixteenth-century society. ${ }^{23}$ A woman's eyes in the profile form, which cannot be downcast, are instead deflected or averted. Thence she is decorously chaste, the

\footnotetext{
Pope-Hennessy, Pontait, 3 .

"Did, 42. The last section of the impression managenew, Simons referenced the sociologist Erving Goffman in his The Presentation of Sell in Everydal Lile, Garden City, N.Y., 1959.

"Simons, "Women", 50 in fifteenth-century society, Women were discouraged to make direct eye contact with a man for fear that he would be tempted by her

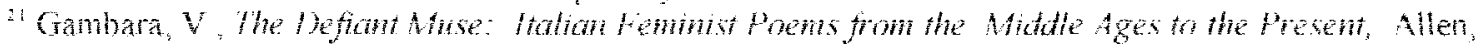
Kittel, and Jewell, eds. New York, 1986. Simons goes on to mention of Gambara's that she was stated as saying with wit that her sonet slips betwen contradictions, not cren requining an unavalable nale object of the gaze: "desire is spent except for you alone, "said to her "blest places.

"Simons, "Women", 50

"Ibid. 50
} 
men to ogle. The Renaissance man possessed an inherent fear of a woman's gaze. Lyrics by Petrarch which claim "her eyes have the power to turn [him] to marble", as well as Pietro Bembo"s remarks of "I gaze defenselessly into a woman's lovely eyes and lose myself ${ }^{25}$ more than assert how an average man of the Renaissance culture believed the supernatural power of a woman's gaze. This "Medusa Effect" must have put a mythological fear of the Almighty into the hearts of all noble men. ${ }^{26}$ Regardless, it was thought that a woman's gaze had the power to utterly bewitch a man to the point which he would lose control over his heart.

Love, as it was generally argued, began with the gaze, when the eyes of the woman set forth a flame. ${ }^{27}$ The power of the image kept the Renaissance painter busy at producing new and innovative depictions of female sitters as ideally passive and modest young women. Theirs are the works which depict women who were viewed in the static form, unable to arouse any sense from men other than their ability to chose a suitable wife based on a profile image. ${ }^{28}$

The transition of the profile into the frontal portrait was a monumental task credited to Leonardo da Vinci (Fig. 4). His painting of Ginevra de Benci has been universally acknowledged as a groundbreaking work. Upon its completion, The Portrait of Ginevra de' Benci must have been one of the most astounding visions to behold. Ginevra, in a three-quarter length image confronts the viewer with a frontal gaze, looking to engage in conversation. Leonardo did not make her portrait into the typical sexually-charged image

\footnotetext{
Simons, Women. 50.

${ }^{26}$ The term "Medusa Effect" is in reference to the Greek Gorgon who was a female monster who possessed the power to turn a man to stone if she gazed directly upon him. This term is used by Simons in reference to the fear which accompanied the fifteenth-century views of the female gaze upon man, and the power entailed there.

$2^{2}$ Goffen, R., "Titian's Sacred and Profane Love and Marriage", The Expanding Discourse: Feminism \& Art History. Icon Editions, N.Y., 1992, 114.

"Simons, "Women", 42-43. It is evident that the profile portrait was intricately involved in the betrothal, dowry, and marriage process. The appearance of the young woman in the portrait, i.e the dress and jewelry she wore, and her level of apparent beauty to the viewer, was intricately involved in choice made by her (future) husband.
} 
universally acknowledged as a groundbreaking work. Upon its completion, The Portrait of Ginevra de' Benci must have been one of the most astounding visions to behold. Ginevra, in a three-quarter length image confronts the viewer with a frontal gaze, looking to engage in conversation. Leonardo did not make her portrait into the typical sexuallycharged image which followed the evolution of the profile portrait. He created an image of a woman which could be seen as respectable, gazing at the viewer in a noncapricious fashion. On the contrary, Palma Vecchio's Profile Porrait of a Latly (Fig. 1) and Porrirait of a Lady called La Bella, (Fig. 2) are images which fall into the category of female portrait prototypes that were prevalent in sixteenth-century Venice.

It has been thought that Leonardo's interpretations of females was abnormal. He portrayed woman as individuais and as possessing inteiligence, as weil as a bioiogicai equal of the human species and philosophical ascendant to the principle in the cosmos. ${ }^{29}$ In the case of the Portrail of Ginevra de' Benci, Leonardo attempted to depict a woman of extraordinary nature. Her portrait, thought to have been commissioned by Bernardo Bembo, points to a characteristic of the woman who was Ginevra de' Benci.

A renowned beauty, Ginevra was a poet in the Medici court of Florence who added a great deal of culture to the court." Scholars believe that the portrait which now hangs in Washington, D.C. was a marriage portrait. The juniper bush behind the sitter's head as well as the inscription on the opposite side of the panel reads VIRTUTEM FORMA DECORAT. A Latin inscription such as this is a characteristic attributed to bridal portraits. ${ }^{31}$ By this observation, Bernardo Bembo could not have been the patron for Leonardo's painting. But we know that Bernardo Bembo commissioned ten poems

\footnotetext{
"Garrard, M." Leonardo da Vinci: Female Portraits, Female Nature", The Expanding Discourse: Feminism \& Arl Hisiory. Broude \& Garrard, eds, icon Eds., New York, 1992, 59.

3 lbid., 61 .

${ }^{31}$ Ibid., 61.
} 
but Ginevra de' Benci, the poet of intellectual virtu

A knowledgeable man might choose to regard a woman as his moral and intellectual inferior, his equal or even his superior. A Renaissance man would have been standing against strict prejudices concerning the female mind and character because of the potentially dangerous otherness that men perceived in women. ${ }^{34}$ Leonardo's aftempt to depict Ginevra as he saw her, as more than a beautiful woman, birthed a genre of female portraiture which revolutionized the depiction of women in art.

Petrarch, the father of Humanism, is given close ties to the execution of Leonardo's Portrait of Ginevra de Benci. Cropper suggests that classic models of this idea would be Petrarch's Laura and Dante's Beatrice. Petrarch's quest to capture the thought of ideal beauty within a pictorial image is thought to be housed in Leonardo's painting. It is easy to believe that in discerning Leonardo's evident admiration for women of intellectual status as well as physical beauty, he was also within a social sphere which celebrated the depiction of ideal female beauty, a sphere which was exclusive to male members.

Aside from the social analysis of Leonardo's portrait of Ginevra de' Benci, a certainty remains: Leonardo possessed an idea about female portraiture unlike the traditionai painter of the fifteenth century. To him, the portrait should project the female as a member of the human race. She is a participant as much as any man, and capable of things

\footnotetext{
${ }_{33}^{3}$ Garrard, Leonardo da linci. 64. Leonard enjoyed a personal friendship with the Benci family. He was a close friend of Ginevra's brother, Giovanni. Another possible attribution to the patronage for the Washington portrait has been given by some scholars to Leonardo himself, who is thought to have painted the portrait out of gratitude for having stayed at the Benci palace

${ }^{34}$ Rancois Rabelais (c. 1494-1553), quoted in Ranum, 244. "nature has placed within their bodies, in a sacred, intestine place, an animale, a member, which is not in men. As expressed by Rabelais, physical professor of anatomy, viewed the uterus as a n entity which was controlled by the moon, and caused frightening behavior in women. This supernatural misunderstanding of the female gender was very common in Renaissance thought

"Garrard references the issue of the paragon of ideal beauty, as created through Petrarch in her article on Leonardo da Vinci on page 61, Elizabeth Cropper's essay "The Beauty of Woman: Problems in the Rhetoric of Renaissance Portraiture", in Rewriting the Renaissance: The Discourses of Sexual Difference in Early Modern Europe. will be referenced again and in the following chapters
} 
Aside from the social analysis of Leonardo's portrait of Ginevra de' Benci, a certainty remains: Leonardo possessed an idea about female portraiture unlike the traditional painter of the fifteenth century. To him, the portrait should project the female as a member of the human race. She is a participant as much as any man, and capable of things which were given only to men.

The Platonic state of mind demonstrated by Leonardo in his first portrait, appears again in his Portrail of Cecilia Gallerani. (Fig. 5) An extraordinary woman Cecilia was the lover of Lodovico Sforza, Duke of Milan. She was "acclaimed for her incomparable beauty and sparkling intelligence".36 Gallerani was noted for her ability to carry on learned discussions with famous theologians and philosophers. She wrote epistles in Latin and celebrated poems in Italian. ${ }^{37}$ Leonardo created a portrait prototype in the I'ortrait of Cecilia Gallerani by displaying a figure which may be one of the first examples of a courtly lady. Cecilia, the mistress of Ludovico Sforza for ten years, was above the stigma that occurred within Renaissance court society and the position of mistresses at court. Cecilia's intellectual renown and high social status was above the traditionally inferior position of the courtier. We see within her an early instance of the courtesan. The woman who was the courtier was a severe contrast to the silent, chase, and obedient wife. She was celebrated as intelligent, accomplished, outspoken, and sensual. ${ }^{39}$ Leonardo's Portrait of Cecilia Gallerani is an image of an admired and beautiful woman of high status at court, but is subject to the malle gaze, even under the brush of

\footnotetext{
"Information on Cecilia's personality comes from Felice Calvi, famiglie Notabili Milanesi, vol III Milan: Antonio Vallardi, 1884,n.p, and from Francesco Malaguzzi-Valeri, La Conte di Lodovico il Moro. Milan: V., Hoepli, 1929, vol II, $465 \mathrm{ff}$

"Information about Gallerani's achievements are praised by Francesco Agostino della Chiesa, Theatro dethe dome letterate (Mondovi, 620 p 124 . All of the above research was perfomed by Mary Garrard and end noted in her article "Leonardo da Vinci; Female Portraits, Female Nature", from The Frpanding Discourse; Feminism \& Ait History. N. Broude \& M.D. Garrard, eds., Icon Editions, New York, 1992, 58-85.

"Garrard, "Leonardo da Vinci", 64

${ }^{30}$ Ibid.. 64 .
} 
praised because she is shown listening rather than speaking, and as a creation of Leonardo's hand, he will succeed in keeping the sitter's beauty alive for generations to come. ${ }^{\text {ii }}$ Leonardo is quoted in a reply to Bellincioni:

"How many paintings have preserved the image of divine beauty of which time or sudden death have destroyed Nature's original, so that the work of the painter has survived in nobler form than that of Nature, his mistress."

The issue of the portrait in the eyes of Leonardo and male viewers such as the poet Bellincioni implies that Leonardo strove to preserve her majesty of thought and intellectual brilliance. Bellincioni asserts that the beauty of the painting itself survives over any of the original ideas pertaining to the sitter, while Leonardo argues in his reply that the preservation of lost beauty is what is at stake. Leonardo insists that the the true image of the sitter does not particularly matter, and the artist, patron, or creative nature itself will take over, resulting in the original sitter to be inconsequential

The sixteenth-century artist who created images of ideal feminine beauty which did not exist in nature alludes to an evolutionary change in the female portrait. Paintings that came to be under the rubric of female portraiture did not always bear a complete resemblance to the sitter. ${ }^{* 3}$

Whatever Leonardo da Vinci's ultimate goal in the realm of female portrait painting may have been, there is no denying his immense influence on the genre. His influence spread throughout the artistic arenas of Italy into different traditions of painting. Looking into the sixteenth century, we see an uprising of a specific purpose of the female portrait, particularly in the island city of Venice.

"Garrard, "Leonarde da Vinci", 65. Bellincioni, Rime Sparse (1493 ed), Malaguzzi-Valeri, 1929, vol, II, 470 .

"Garrard, "Leonardo da Vinci". 65.

"Many of Palma Vecchio's portraits have been thought guilty of this. Some of the female figures appear to portray an artificial quality which many historians have thought to be wonen figures which were conjuring of the artist's imagination. In his book on Pama Vecchio, Rylands mentions that of the twenty female images, they must have been intended as portraits. It is possible that they are generalized images, where the sitter did not exist. 
Whatever Lconardo da Vinci's ultimate goal in the realm of female portrait painting may have been, there is no denying his immense influence on the genre. His influence spread throughout the artistic arenas of Italy into different traditions of painting. Looking into the sixtecnth century, we see an uprising of a specific purpose of the female portrait, particularly in the island city of Venice.

Virtually untouched by invaders for centuries, Venice was a fantastically wealthy and decadent city unlike anywhere else in Renaissance Europe. The art and artists in Venice came to be world-famous, as well as the women who were portrayed on the canvases. Criticism by the tourists at that time who visited Venice spoke of the decadence of the women and the permissiveness of a society which was greatly reflected in the paintings by Paima Vecchio.

A contemporary of litian, Palma Vechio produced his own oeure of female portraits which have puzzled art historians for decades. The group of approximately twenty paintings of unidentifed women came to be scattered about the world after Palma's death at the age of 48 . Some analyses of the portraits claim the paintings were not intended as portraits of individuals, but as generalized and profane statements of feminine beauty inspired by courtesans in the spirit of the Petrarchan poetry revival then in vogue in Venice." Inded, the general analysis of the paintings as a whole are very good examples of Petrarchan poetry and ideal beauty. But on a closer examination of two paintings from this group, Portrait of a Woman called La Bella and Portrait of a Womum in Profile, are notable examples of the traditional portrait painting taken to a different level. Palma appears to have achieved the standard of ideal beauty within this small group of paintings. He created images of provocative and beautitul creatures, illusions of

\footnotetext{
"Mandel, C.,"(Jacapo)[Giacomol Palma (1) Vechio", The Growe Dictonory of Ant Onime, Oxtord Un. Press, Accessed March 30, 2004, «http//www groveart com>
} 
what men wanted. Palma followed the traditional techniques of portrait painting and added tantalizing twists to his compositions which tell a story about the women within the frames, as well as the men who gazed at them.

A probiem surrounding Paima's paintings is the fact that most art historians have, in a swift generalization, made all of the sitters courtesans. While this is an idea to contemplate, it produces speculation into another question involving female portriature in the Renaissance. The issue of identity in female portraiture needs to be discussed.

An inventory conducted in 1529 of Palma's studio lists contents which were ategorized in an advantageous manner. The male portraits which remained in his Pama's studio were identified in the same way: Portrait of Pier Antonio Zorai, The Man from Murano, etc. the identity of the sitters in the paintings, save one, were anonymous." Identity of female sitters in Renaissance portraiture is not a modern misunderstanding, nor was information about the patronage and sitier lost. The sitters in these images were never intended to be given a definite identity. Why was this? Cropper states that many portraits of unknown beautiful women are now characterized as representations of ideal beauty in which the question of identity is immaterial.$^{\text {th }}$ No unidentified male portrait, on the other hand, is ever said to be a beautiful representation made for its own sake. A technical explanation is called the symecdoche for beauty. By this she means that the representation of beauty, or a woman who was physically beautiful, was also seen as beauty itself. ${ }^{47}$ This is very similar to the dilemma which Leonardo seemed to have faced in his Portrat of Cechia Gallerant. Leonardo's wish to express the nonphysical qualities of the sitter in the portrait, are overshadowed in the paintings by Palma. The viewing audience, which was predominately male, requested a personification of physical beauty "Ryiands, P., Paima Vecho. Cambridge U Press, 1988,93

"Cropper, M., "The Beauty of Woman: Problems in the Rhetoric of Renaissance Portraiture", Rewrititg the Renoiswance. U. of Chicago, 1986, 178

4' Cropper. "The Beauty", 176. 
wealthy means. Palma's La Bella mirrors Titian's painting by the same title. Although

little is know about the attribution or patronage associated with Palma's La Bella, much is known about Titian's painting. (Fig. 6) Commissioned by the Duke of Urbino, he wrote to Titian requesting that the "portrait of the lady in the blue dress to be finished as soon as possible, and also requested that it be beautiful. ${ }^{48}$ The Duke's readiness to purchase a painting of a beautiful woman whose name he does not mention and probably did not care to know, has led to speculation about Titian's purpose in painting it. Ironically, the woman in Titian's painting has been identified as the same woman who posed for Titian's Venus of lirbino." Did, in fact, the Duke of Urbino simply commission a painting of a beautiful woman to satisfy his visual appetite? It is logical to assume that the two paintings entitled $L a$ Bella were created under the same pretenses.

Since the time of commemoration and dynastic identity in portraits, the art of portraiture changed in the eyes of the Venetian artist. The transformation in portraiture that occurred in Venetian schools of painting resulted centuries later in the modern attempt to classify the erotic works, such as those produced by Palma, into a cohesive group. 'Paintings of people's1 is one attempt at the classification. Another was to simply call the erotic images the first pin up. ${ }^{52}$ Neither of these is a fitting generalization. Clearly

\footnotetext{
${ }^{48}$ Cropper, The Heanty. 179

${ }^{40}$ Tbid. 179.

Ibid., 179 .

"Hirst, M., Sebastiano del Piombo. Claredon Press, Oxford, 1981, 93. Hope later states in his article Problems of Interpretations that it has been often argued that pictures of this type, which were by Venetian artists, have a complex philosophical content, usually associated with Neo-Platonism. Pope does not agree with this argument, as well as my self. The fact that there were so many paintings of this kind being produced in Venice during the sixteenth century, is evident that paintings of erotic content, mythological or non, was very popular and in great demand by the wealthy male citizens of Venice.

"Hope, C., "Problems of Interpretations in Titian's Erotic Paintings", Tizicano e Venezia: Comvegno Internazionale di Studi. Neri Pozza Editore, Venice, 1976. 119. Hope makes the statement that the tradition of the pinup girl seemed to have gradually developed. He refers to Giorgione's Laura which is a threequarter image of a young woman with one bared breast, but is also wearing an expensive fur-lined cloak. I believe that this a generalization which has been clouded by the modern idea of the pinup. A more noble desire was present in the patron's wish to procure paintings such as portraits produced by Palma. These women were more akin to wishful idealizations of what the men desired in the fairer sex.
} 
group. "Paintings of people'st is one attempt at the classification. Another was to simply

call the erotic images the first pin up. ${ }^{52}$ Neither of these is a fitting generalization. Clearly there was a portrait type that was produced to the specifications of the patron. Images of women were made for a paying clientele which were not specific indivduals, but idealizations of women who may have appeared in several other paintings by the same artist. Examples of this are seen in several paintings by Palma. One version of Palma Vecchin's Lady with a Iute, described by Marcantonio Michiel as 'a canvas of a woman. waist length, who holds in her right hand a lute, and has her left hand under her head, by Jacopo Paha. ${ }^{54}$ The same woman is said to appear in Dresden's Three Sisters, another of Palma's canvases depicting a female type of three women sitting in different positions. Palma was not the only Venetian artist known to use the same model in his temale portrats. Titian used the same model in his Girl in the lur Coat and the Venus of Urbino; both images of ideally beautiful types of female portraits."

This type was what Palma must have followed when he executed his female portraits. Although he must have been schooled in the art of depicting a sitter in a noble

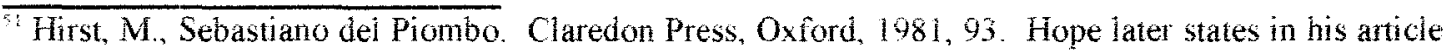
Prohlems of interpretations that it has been often argued that pichures of this type, which were by Venetian artists, have a complex philosophical content, usually associated with Neo-Platonism. Pope does not agree with this argument as well as myself. The fact that there were so many paintings of this hind being produced in Yenice during the sixteenth century, is exident that paintings of erotic content, mythological or non, was very popular and in great denand by the weallity mate chicens of vence.

"Hope, C., "Problems of Interpretations in Titian's Erotic Paintings". Tiziano e Tenezia: Comegho Internazionale di Studi Neri Pozza Editore, Venice, 1976, 119. Hope makes the statement that the tradition of the pinup girl seemed to have gradually developed. He refers to Gorgione's Laura which is a threequarter image of a young wonan with one bared breast, but is also wearing an expensive fur-lined cloak I bolicve that his a gencraization which has becn clouded by the modern idca of the pinup. A more noble desire was preseni in the patron's wish to procule paintings such as portrails produced by Paima. These women were more akin to wishful idealizations of what the inen desired in the fairer sex.

'Tinagli, Women. 102-103. Tinagli proposes that in contrast to the art of portraiture in Florence, which was adamant about familial representation and lineage through female portraiture Venice was immune to this ned The traditon never took root in the Senensmo where the political and social structure were disparate from the feuding teritories in Tuscany. Instead, a type of potraiture developed on its own, producing three-quarter-length images which are prevalent in the oeuvres of Palma Vecchio, Titan, and Paris Bordone.

"Tinagli, Women. 103.

"Thid 103
} 
fashion, the professional art community in Venice pleased the wealthy male populace with stunningly erotic images of nameless beautiful women. ${ }^{37}$

In Paima's Portrait of a Woman in Profile, (Fig. 2) the pronile of portrait is given an unexpected twist. The sitter coquettishly looks from over her shoulder at the viewer in a coquettish mamer while she gestures with her left hand, exuding a willngness to undress herself. Men were meant to gaze upon this image, for she looks to be acting of her own free wili. There is no notion, on the part of Paima, to appoint control upon the siter, as was done in the profile portraits of the frfeenth century. The apparent fear that clenched the hears of the Renaissance man has tansfoned inte something firtatious, bordering on the erotic This painting conld be seen in direct correlation with the innovation in Leonardo s Portrat of Ginevra de Benct who depicts the sitter to be interating with someone outside of the picture piane, and looking directly at the viewer. Palma Vecchio was following the boundaries within the art of portraiture. But it is also clear that he was greatly influenced by the eroticism which had taken over the world of Renaissance female portraiture in sixteenth-century Venice.

\footnotetext{
Paima s work stylistically suggests that he was apprentice to Andrea Previtali, who studied under the master Giovanni Bellini. This is cited from the excerpt from the Grove Dictionary of Art online $<$ http:/www groveart com>

The man type of pantings executed durng the fffenth century at that the induded either entica wht mythological figures and nude fenales or the traditional altarpice which was continualy being strethed to new himits. Paima Vechio's ocuvre reffects the change from eariy to a High Renaissance concepion of the human figure in secular and religious art. His specialization was the SACRA CONVERSACIONE, paintings of the Virgin and saints in a rural setting. The paintings in question which a re the three-guaterlength paints of women were not what he was known for while he was alive
} 


\section{CHAPTER II}

\section{TIIE POETIC IDFAL OF FEMININE BEAUTYY IN THE PAINTINGS OF PAIMA VECCHIO}

The development of the femaie portrait evolved towards the end of the finteenth century into a female portrait prototype. The expectations of women in Renaissance society may be easly read through the suggestively erotic mages that became a Ventan art form. Following the emerging new art form of the prototype of female portraiture, a hobby for weathy nobiemen in venice became known which coupled the commissioning and collecting of painings of beautul women with works of prose. The peetry, ether influenced the paintings on was writen upon the completion of the inage. While the poess wrote of the images that captured their literary minds, their words manifested complex ideas of ideal teminine beauty. Ideal poetic beauty is evident in Palma vecchios series of twenty femate portraiss. The identity of the sitter in the paining was not a pertinent matter for the individual commissioning the painting. The prototype of female portraiture embodied the physical elements desired in fantastical female benuty.

A common argument in the Renaissance existed between poet and painter that concerned which was the purer form of an, painting or poetry. Upon closer observation,

\footnotetext{
Rylands, P. Falma leccho. Cambndge Unversity Press, Cambrige, 1992, 84. Rylands clams that in Palma's oeuvre, excluding the "Nudes in a landscape", over twenty surviving female portraits fit into the grouns of paintings discussed in this paner
} 
this argument mirrors the age-old question of the chicken and the egg. Therefore it is important to understand that the two, painting and poetry, coexisted and relied heavily upon one another. Without the two, we would not have received the numerous paintings which can be categorized as female potrait prototypes.

During the evolution of the portrait, poetry was frequently witten which praised specific paintings, along with the artist's ability to render such images. In his endless endeavor to achieve the worid of the Classics Renaissance man would have been aware of the beliefs of the Greek phiosopher Horace who believed that poets and painters were equal in the realm of inventive inagination of more commonly called potic license. Philastrus a student of Aristotle, claimed that poets introduced the gods upon their stage. and with them all the accessories of dignity, grandeur and power to charm the mind. Painting does so with figures in the visual manner, as do poets, who are abie to visually describe in words.

In a poem by Bellincioni, he writes about Leonardo's portrait of Cecilia Gallerani, claiming that Leonardo had immortalized Gallerani in paint. ${ }^{63}$ Leonardo always the man of quick opinions, is quoted on the issue:

"If a poet says that he can inllame men with love, which is the central aim in all animal species, the painter has the power to do the same, and to even a greater degree, in that he can place in front of the lover the true likeness of that which is beloved, often making him kiss and speak to it. This would never happen with the same beauties set before him by the writer. So much greater is the power of a painting over a man's mind that ho may bo cnchanted and cnraptured by a painting that does not represent any living woman. ${ }^{2 \% 2}$

Leonardo's statement encompasses a phenomenon not spoken of beforc. It is the

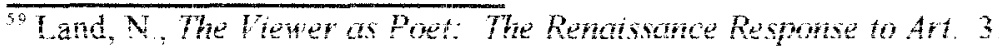

Phiostratus the Younger, Magmes (LCL), trans. Athur Faibanks, 285

"Gamard, M., "Leonardo da Vinci. Female Portaits, Female Nature", The Expanding Thwomiw: Femimism d Ar Hishory. Broude \& Garrard, eds., icon Eds. New York, 1992, 05.

i2 Martin Kemp ed, Leonardo on Painting: an anthology of writings by Leonardo da Vinc with a selection of docments relating to his carcer as an artist. Yale Iniversity Press New Haven 108926
} 
function of the painting. The image affords erotic arousal within the men looking unon it

The beauty of a woman could be depicted in a way that would induce the man to rely

upon the image for comfort. Rogers speaks of the speli which was cast upon a man who posscssed such paintings and sought the images to ho and brcath for their sake. ${ }^{63}$ it appears that Leonardo was the first creator of mages that evoked contact between the sitter and the viewer. His portraits of Ginevra de Bencl and Cechia Gallerani, perfected the affect of the painted image which enraptured the male viewer. Rogers asks why this inovation took place, and the answer is smple. The movation of fenate portature from the profle into the three guater length portait was evolved and new expressive qualities were developed Graceful liveliness and a deceptively 'real' presence which were seemingly responsive to the spectator, were extolled in the poems." An example of this interaction between the art and the vewer is mantest in the wor of scuptor lutho Lombardo. Fig. 9) Lombardo was known for creating marble busts of womon that cout have elicited the kind of movements and interactions which poets of the Italian sixtenth century would identity as laughter, glances, movement and speech Brocardo's admiration of a mabie bust of Tuhio Lombardo is seen in his written verse describing his imaginings of her in fesh and blod. A search for ideal beauty to be depicted in both forms of art, poetry and painting, were sought in the talent of the artist. There was great need for the perfect female form within the work. which nature could not accomplish. The Renaissance quest for perfect physical beauty is evident in the writings of Giovanni

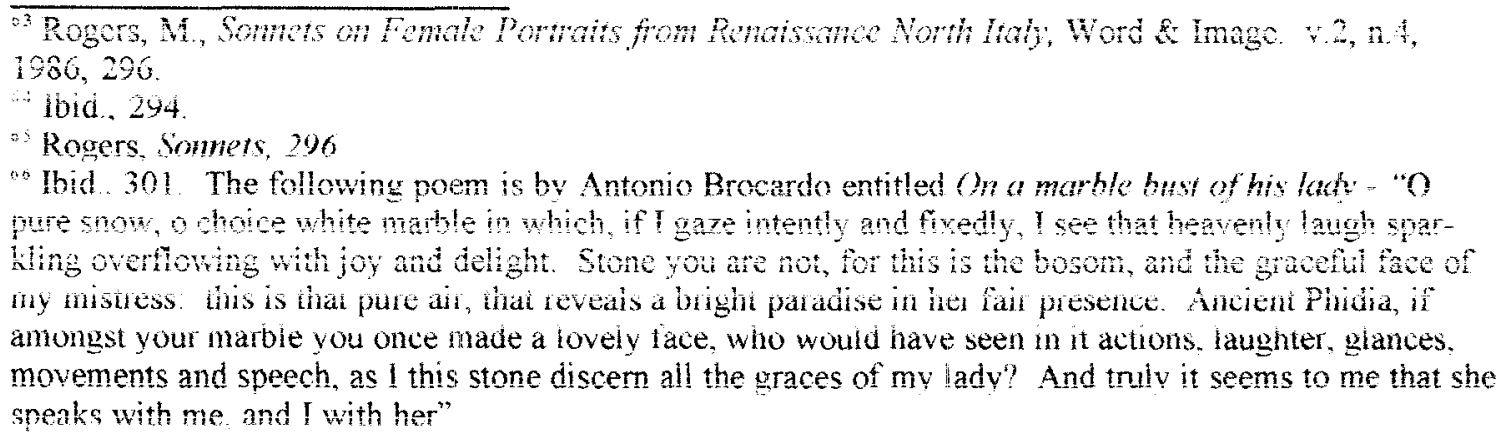


"in female portraiture beauty with exquisite delicacy will be seen. improving the mistakes of nature whth an as far as is possible, in this mitating the poets when they sing their praises in verse.

Artsis we encouraged to smooth the natual imperfectons of the stler into a viswa of perfection not found in nature

I he shift to the three-quarter length female portrait trom the profle could be seen as a ceicbation of Petrarchan verse. Petarch's words deschbed divine elements of female beauty as such: bright eyes, high brows, pale skin of alabaster or vory with rosy cheeks and lips, a whitc ncck and porhaps also bosom and hands. Living and writing in $1304-$ 1374. Hrancesco Petrarch is the most accomplished lyric poet in the Italian vernacular. Possessing an ardent desire to revive the knowledge of antiquity, Petrarch was known as the procurer of ancicni manuscripts. Ie is porhaps best known for his Canomiere, a body of love poetry which is a lengthy description of his "keen but constant and pure attachment to a woman who would become his muse, named Laura." Within his Canzontere Petrarch speaks of when he first gazed upon Laura. The infatuation which followed tumed into an enuless relgious struggie in his love for her, and the torture he fent when she died of the plague twent years after the love affar began. Whin the Can-anicre lies description of how one man envisioned the woman he loved and the ideas which influenced a literary and artistic movement. His was a vision that became the

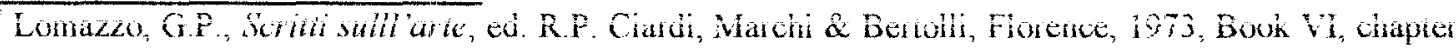
51. Rogers, "Sonnets, $29 \%$.

"Blanchard, H.H., Prose and Poetry of the Continental Renaissance in Translation. Lonoman's Green $\&$ Co New York 10493
} 
rebirth of Humanist thought which greatly involved the ideal of feminine beauty

There is ample evidence of followers of the ideas of Petrarchan beauty in the

sixteenth century. A Venetian poet by the name of Galeazzo Capelia, in his Delia

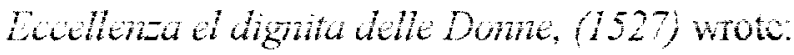

" beginning with the eyes, which at night are like two flaming stars, or instead two living suns spreading their lights about them, and with their clarity conquering the shadows of the night.. What shall I say of the broad forthead? and of the curved evebrows? of the refined nose? of the vermilion

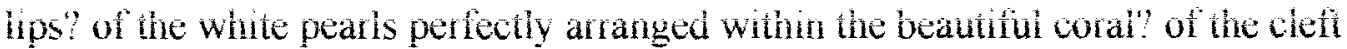
chin with no trace of hair? of the lively colour of the whole face? what of the white throat? what of the soft goid threads, which on the ivory white skin are spricad?"?

This passage is one exampie of the greai influnece of Petrarch s ideals of feminine beauty, and how they are manifested in sixteenth-century poetry and panting. The sory of Petrach and painter Simone Martini is example of the endess quest to capture ideat beaty in paint Petrach commissioned Martini to complete a painting now lost, of his beloved Laura. He wrote severa! poems praising Martini s artistic ability as a painter, combined wh the power the mage welded in his eyes." He also expresses his disbelict at what Martini was capable of producing in pant, as well as his own desire to accure

\footnotetext{
"Dlanchard, $P$ ose 10 . The following is a good example of Petratch's iteal beaty as expressed in his

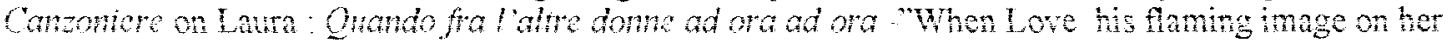

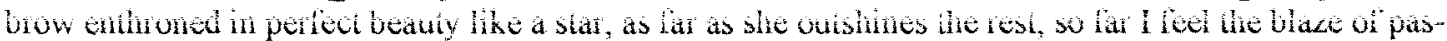
sion surge and grow. yet still 1 bless the place, the hour when so supremely high, at igint so singuiar $i$ dared to look: "O heart, you blessed are to gaze upon that pure, that goiden glow", I murmur. "She inspired the splendid thought which points to heaven and teaches honest eyes all worldly lures and winnings to despise: through her that gente grace of love is taght which by the straight poth leads to paradise, and cuer here hope's holy crown in wrought." (Auslander)

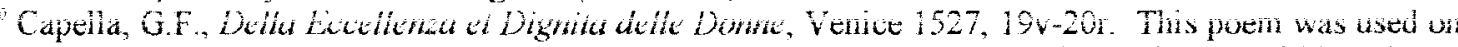
page 94 in Kyland s book on Palma Vecchio when speaking on the poetic ideal of beauty within Paima Vecchio's group of female portraits.

"Rogers, Somnefs, 300. The following poem is a work by Francesco Petrarch On Simone Martin's por

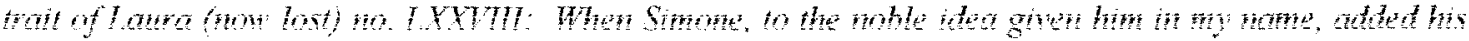

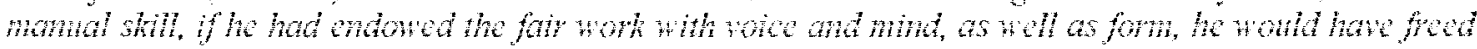

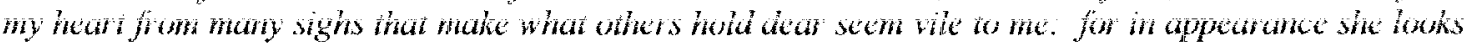
humbie promising me peace in her cxpresson. But when I come to speak wih her, she seems o listen very gracionsiy: if only she could reply to my words. Pyomalion, how happy you must be with wour image since you ohtamed a thomend times what I long io have inst once.
} 
what the Crock scuntor Pygmalion receved from Venus in the ancient Grod myth"

Although Petrarch was a malor inspiration to the ideals of poetic ideal of beauty. the sixteenth century painter came to develop his own vision of it. The Neo-Petrarchan

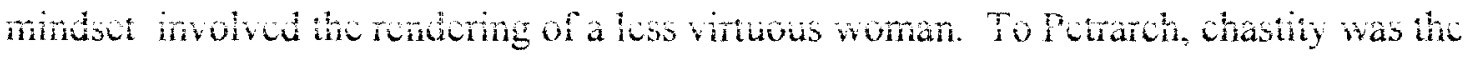

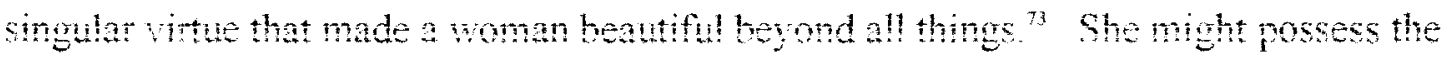
noted gualities of the pale, smooth skin golden hair high forehead and gently arched eyehrows, but in many cases painters in Venice were creating diferen compositions.

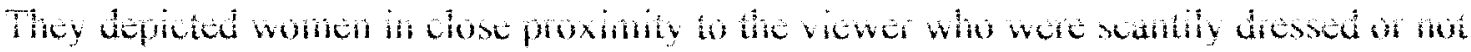

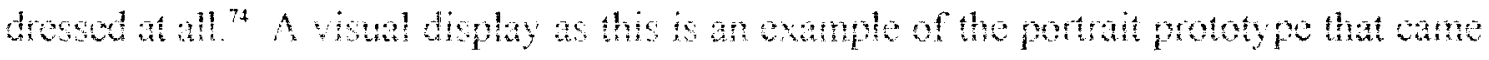
to be a common practice in the firs half of the sxteenth century A woman mosesing the ideal standards of Laura was physicaily and emotionally unapproachable According to Rogers, she wouk express inmihy and sweetness which potentahly could cespond to the viower whth pity. While this ideal was taken gronty into consideration and utined in portraits by court painters such as Pronzino, the Venetion schod of nainting and other ldeas in mind.

In the artists circle of Giorgione, Tiluan, Pama Vecchio, anu Paris Boroune in Vonice, numorus portaits were produced whoh contain loose Neo-Petratchan views. The fleshy interpretation of Petrarch's ideal beauty made the sitter more approachable, or

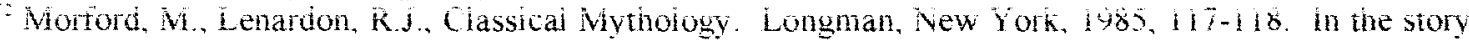
of Pygmalion. Venus grants life to a beautiful, lifelike sculpture which Pygmalion created and then tails in love with. As the myth is told on the most holy of the feast days of Venus on Cymus Pygmation

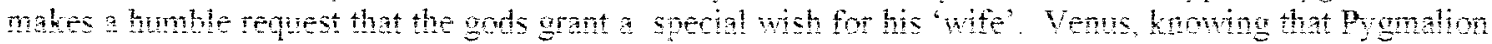

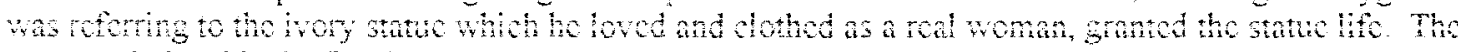
two inatred and had a family.

Rogers, M., "I he Decorum of Women s Beauty inssino, Firenzuola, Luigin and the Represenation of Women in Sixtcenth-Century Paintino". Renoisance Sudies. v. 2, n. 1, 1988.51 Of the three writers discussed by Rogers. Trissino Lugni and Firenzuda the diverse ideas expressed affirm that of the vir

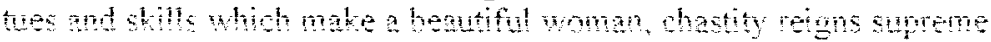

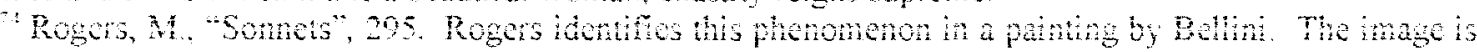

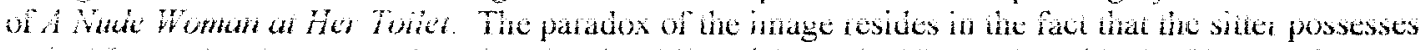
typical Petrarchan beauty, embodying the chec klist of the typical Petrachan ideats. Tet the close proximity of the viewer with the sitter, as well as the fact that the lady is nude, adheres to the Neo-Petrachan ideals of female nortraiture
} 
porhaps invited the vicwer to take delight in the sitter. Some of images may have also represented mythologica! figures or specific idealizations which were manipulations of the real-ifie modeis."

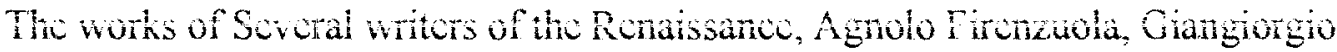
Trisino, and redingo Lugini are authors whose work parallel the painted fantacies and ideas of female beauty as portrayed in female portraiture. To say that these men were writing in the classic Petrarchan tradition is faise, aithough Petrarch was cleariy an insporation. Ther thoughts and ideas concming ways whoh female beaty shoutu be depicted and appreciated were qute diferent fom the traditonal femate ideals of Petrarch

Agnolo Firenzuola s work La dhalogo della bella domna is a two-part book in when the man thatacter, Celso, is conversing whin fou nobiewomen on the discourses of feminine beauty. It is Firenzuola who uses this guise to express his ideas on the subject. The four women guestion Celso on what physical beaty in a woman should enommass Celso begins his answer with describing nature and several ditterent elements. The clemenis are leggladria (elegance), maesta (majesty), vaghezza (charm), and venusa (loveness)." The four characteristics which adhere to a woman's outward behaviour, rather than her physical appearance, are discussed first. Celso states that like the beauty of art beauty in women is formed from a certain harmony and order among parts. Harmony creates delight in the beholder and has the power to draw the mind to a desire for havenly things.

In the second dialoge, Celso speak of the elements of physical beaty which are

\footnotetext{
"Rogets, "Fonnets", 204

"Firenzudia, A., On the beatity of Women. fist pubising, 1540. Tiansiated \& ed by Konad Eisenbichler \& Jaçueline Murray, U of Pennsylvania, Phiadel phia, 199\%, 30-43.

Cropper, E. "On Beautiful Women, Parmagianino. Petrarchismo, and the Vernacular Style". Art Bullein. $58.1976 \quad 379$
} 
Petratchan in origin. The different colors of lips, correct ways of wearing hair and the proportions of the body, as well as the correct level of tairness a woman's face should carry are addressed. it is quite remarkabie to see that Firenzuola very carefuly and doquently mapped out the sixtconth-combly list of clomonts to make a ravishingly beautiful woman.

Surprisingly, after having been subjected to a certain amount of misogyny, the

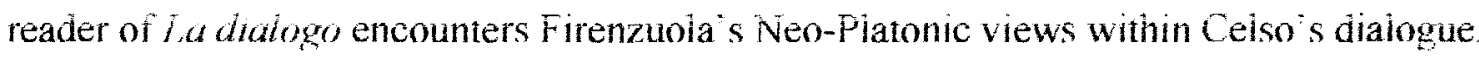
They are views which argue for an equalty between the sexes and an understanding between the nature of men and women. It is a fair supposition to clain that Firenzuola had any design of feminist thought But Firenzuola declares from Celso's lips: "we are one in the same thing, one and the same pertection, and you must seek us and love us, and we must seek and love. You are nothing whout us, and we are nothing without you. Our perfection is in you, and your in us."

Giangiorgio Trissino author of 1 ritwott, wrote of a more decorous and restrained woman depicted in an ideal form of beauty. It seems as if Trissino s subjects are painted as distant aesthetic contemplations with no hint of erotic desire. Trissino writes of reallife noblewomen, such as Isabella d'Este, who whod for nothing more than a virtuous depiction of themselves without any shadows cast upon their virtue. ${ }^{n}$ To Trissino, ladies were exquisite artefacts. carefully crafted out of precious materials. Trissino is compares women of his mind s ideal of beauty to cold, hard substances such as ivory, alabaster, and mable." His wonch belong on a pedestal conveying a lofticss which is conpatible with women of noblity

Federingo Luigini wrote of a female ideal that is the opposite of those in Trissino's

\footnotetext{
Firenzuoia, A, On the Beauty. 21

"Rogers, M." "The decorum", 54.

* Thid 60
} 
writings. In his prose entitled Thro della hello donna, he does not speak of the viruous qualities of the female figures. The subject of his writings concern the nude female figure. Luigini wrote in an uninhibited fashion that discusses every part of the femaie body. His prose was constucted in a mantor whoh spoke of porsons who did not cxist. Penaps his images of beauty are mythological characters taken from Classical tradition, personifications of Circe or Venus, ${ }^{* 2}$ figures who are far from the chaste females represented by Trissino. Luigini s writings on the beauty of women are the opporsite of the ideas espressed by Trissino." Trissino, spoke of perfect physical quahties of women and their vines, as demonstrated though their dress. This is contradicted by Lugini's blatant denouncement for the need of such accoutrements. Luigini then proceeds to state that women are most appropriate when not clothed at all ${ }^{\circ+}$ Lugmis words are ummistakably for the world of the mate fantasist.

From an analysis of Firenzuola, Trissino, and Luigini, the woman of the sixteenth century was viewed in different regards, yet was viewed in the same perspective. She is seen for one purpose and one only: to be shown in the light of ideal temmine beauty as originally described by Petrarch. Looking through the lenses of Firenzuda, Trissino and Luigin, female beauty was shown either fully clothed or undressed. She might have been the spectator and the subject of men's fantasies, or she may have been a respected noblewoman. who wanted nothing more than to be viewed on a pedestal with her chastity

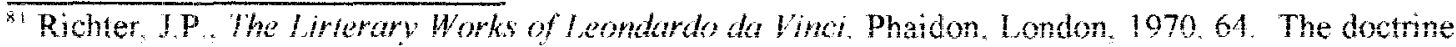
Which is witen by ligin concening images of women who do not exts is tso seen in the anmetion of the followers of Lonardo. Lonardo sponks of the potent spoll that a naturalist painting wan cast upon a viewes: "The panter's power over inen's minds is even greater [than the poets], for he can induce them...to fall in love with a picture which does not portray any iving woman. it once happened to me that i made a picture representing a sacred subject which was bought by one who loved it and who then wished to remove the symbols of divinity in order that he might kiss her without misgivings."

${ }^{2}$ Rogers, "The Deconm". 54 Venus, the Greek goddes of phyod love and beauly Circe is the enchantess daugher of the sun and ant of another Grech encinantress, Medea.

"Rogers, "The Decomin", 61

"ibid. $61-62$. Rogers speaks of a passage by, Luigin who debates about the ellectiveness of an adorned or unadorned woman. The resolution is in favor of the depiction of nudity in painting. Luigini even implores the audience to make the female sitter in the painting nude in their minds if the subject is clothed
} 
reigning as her greatest vitue. Regardless, linked to all of this was the desire to inspire the reader into believing that a woman of supreme beauty existed. As a result, that personification was conjured through paint and developed into the prototype of femaie

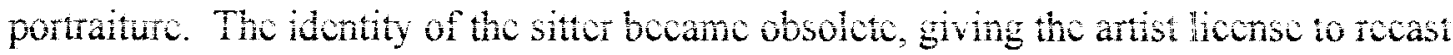
the sitter into a personification of beanty not found in nature

The abundance of images which reflected ideal female beauty poses a question: Was the male viewer in the Renaissance looking for something more than a picture of a

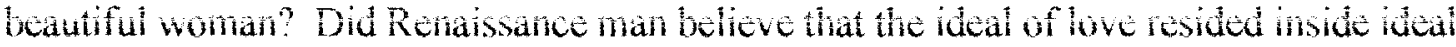
fominine beaty? It is peoliar that there came to be an abudance of frontal female portraits in the sixteenth century when in the fifteenth century a considerable amount of fear was associated with the direct gaze of a woman. Although there were men spouting ideas conceming how women ought to be depicted, hey aiso created an unequivocal evi Which granted power to the female figure on the canvas.

A clear description of the fear and pin experienced when falling for a bentitul woman is seen in Petrarch. Numerous verses were written of the excruciating pain he telt in his inabihty to express his love for Laura. Petrarch continualy warnea his readers of the perils of love and the pan which one would inoviably infict upon himself if he

\footnotetext{
Petrarch, $F$, For Love of Laura Poetry of Petracii Transiated by Manion Shore, in of Arkansas press, Fayetteville, 1987,23. The following poem written by Petrarch in his Rime Sparse is an excellent example of his inability to express his love for Laura. XX - Ashomed cometimes my lad that I stll con-

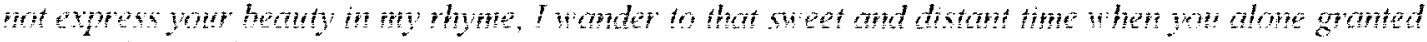

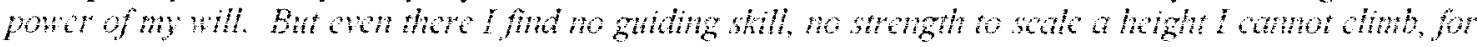

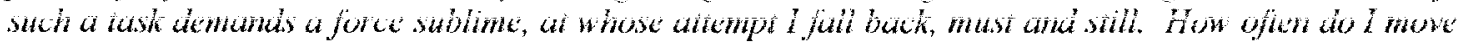
my lips to speak and fird my volee hes burled in my breasi - but then. what sourd conde ever rase so high? How often in verses to I seek to find the words my tongue cannot express, but pen and hand are vanguished each ty
} 
In Firenzuola s La Malogo della bella donna. Celso gives an answer to a question concerning what a man conceived when he looked upon a beatiful woman, and would happon if he found hot to be of suppassing boanty.

"...since each of us desires with a natural instinct and appetite to be reunited with his other hat and become complete once again, it is inevitabie that she should appea beautiful to us, and since she appears boatifu, it is instable that we love her because true love, according to what the entire platonist school clains, is nothing else but a desire for beauty. Loving her, it is inevitable that we should seek her out; seeking her, that we should find her; finding her that we should contemplate her contemplating her that we should rojoice in her, rojoing in her, that we shoud recive from her an incomprehensible pleasure, for pleasure is the end of all action."

Frenzuda admits that upon vewing any beautiful woman, instant love will occur because man is in constant search for pleasure, and a beautiful woman is what will conjure such pleasure, Firenzuola s admitance of the ease of lailing in love, leads to a relationshp between Renaissance man and a painted inage of idcal female beauty. Shce man strove for beauty, and seeng a beautifu woman is the creator of beauty it is easy to see how even a conjured image of a beautiful woman would in the end induce love and pleasure

There is mple evdenes that Patma Vecho ahered to the poetc ideal of beany. In his Pontuit of a Woman in Bhe (Fig 7 ) he executed a frontal portron where the sitter is looks directly at the viewer. Her appearance is one Inssino would possibly approve

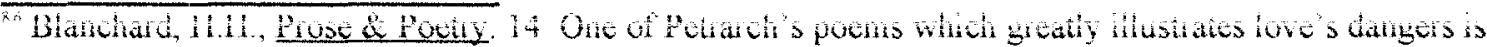

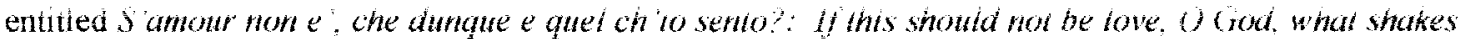

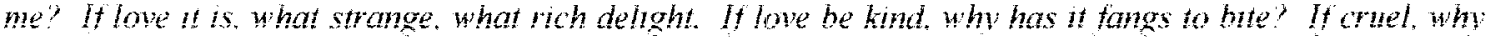

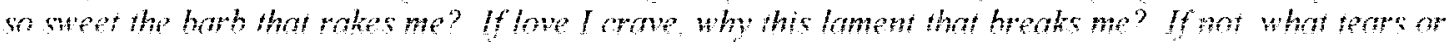

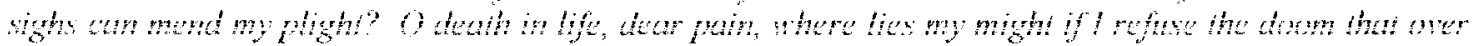

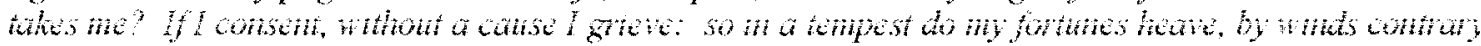

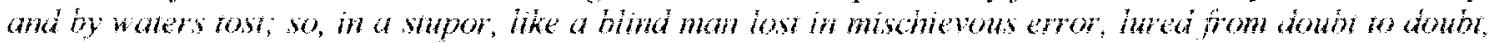
June treezes, January thass me oul. (Ausiander)

Firenzuola A On the Beauty $18-19$
} 
of yet there are elonents which suggest that she is a more than a haughty noblewoman.

Depicted her in a posed position while holding a stylus she possesses flawless alabaster skin, carnelian lips, and golden tresses. The pen she holds in her right hand intimates that she is an culucated womat of leters. This gives her an air of chastencss and virtue upon first glance. Yet there are certain peculiarites with Palna's Woman in Bhe. In comparison with other traditional frontal female portraits, there are elements which make Paima's sither more aliuring than a portrait such as Bronzino's depiction of Laura Battifen, (Fig. 10) which shows a very chaste and beautiful woman presentod ha anch more formal presentation. She sits with stutuesqu posture and an intinidating ait, all the while holding a book of poetry in her hand to represent a chilly idealization of a vintuous woman of the aristocracy. Trissino would be very pieased with this depiction of Lucrezia Panciatich, for she is a representation of a beatiful and chaste woman.

In the regards to the Woman in Bhe, the sitter is a clear exumple of Firenzuola's or lugini's ideal tor a beautiful woman Her hair, which in Renaissance society wonld have been bound upon her head beneath a vel, snood, or turban. falls of of her shoulders. This depiction of a woman in a portrait does not confonn to the approprate hair style fit for a woman of Trissino's regard. According to Luigin, Petrarch's unwed Laura wears her hair loose, which would have been seen as a modest act of behavior, indicating to the men that she was unavalable. ${ }^{* *}$ This would have also muted the erotic impact of the flowing locks of hair. It was known that heads were kept covered to keep desire in check." Paha's lady wears her golden locks in loose braids which flow down

\footnotetext{
${ }^{3}$ Brock, M. Bronzmo. Flammarion, 2002, 94-95. Brock speaks of the portrant of poetess Laura Batnteri with whom Bronzino had a Platonic relationship. He clearly demonstrated his respect and esteem for Laura in this portrait, which shows her holding a book of prose, and depicts her in a pose which hatkons to a profle sketch of Dante Bronzino drew in 1532.

Rogers, Dowomin, 62 .

Luigini, F. Il libro delia belia doma Venice, 1554, Engish transiation, E.M. Lang, The Book of Fair Women by Federigo Luigini of Udine', London/New york. 1907,232.

: Rngers M. The Decortm, 62
} 
her back, as well as a flower tucked bohind her left ear. Apparenty, a woman's loose hair cast a great deal of tension upon the Renaissance woman. The response to the sight of golden tresses tumbling loose, cast an erotic spell, and connected the image with the alluing goddossos and sirons from pagan antiquity

In Palma's Votante (Fig. 8), the vewer catches a glmpse of a woman who atheres to Luigini's ideals of beauty to an even greater degree than the Woman in Bhe. A coquettish look upon the sitter's rosy lips tells the viewer that she is looking to be admired for her bvelness. Her low neckine adomed with a violet, her name, and her abundant golden hair which nows down her back, is a recommendation of the ideals of beauty posited by Luigini

Violantes dress is exquisite, that of a woman of means, but this is not a depiction of a noble woman who is striving to keep her vitue intal. The position whin which Violante is sitting creates a very intimate situation. The intimacy suggested by the composition and the position of the sitter creates an arena for her bosom to be ogled by a vewing audience. The sitter appears to be fully aware of this lact and seems to revel in the idea that she is the prime subject of the viewer's gaze."

It is clear that Palma Vechio was an artist who falls into the Italian Renaissanco circle of artists who strove to depict a ideally beautifu woman acording to the provocations from the poetry of the time. The Petrarchan ideal of beauty which became a cultural ideal for men and women alike, was ciearly followed whin Paima's compositions Wonan in Biue and Volante. Like his affuent contemponary, Titan, he appears to have executed many of the pantings for the pleasure of the wealhy nen of Venice. Whether or not these anonymous portraits of beautiful women were in fact

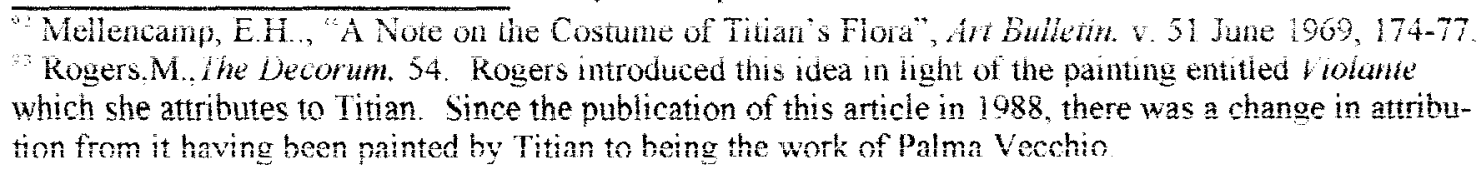


There is a need for further examination into the social ideals and demands on women at the time. The manner with which women were expected to appear depended greatly on the art and poetry produced. Although present scholarship has made great strides in womcn's studies during the Renaissance, there are still many pressing questions. Clearly the effects from the coupling of painting and poetry upon the fairer sex was elemental. It not only affected the ways in which women were viewed by outside audiences, but how the sixteenth-century woman viewed herseif. 


\section{CHAPTFR III}

\section{THE COURTESAN IN THE PAINTINGS OF PALMA VECCHIO}

The courtesan in sixteenth-century itaiy was the most educated and independent woman in the world. ${ }^{24}$ She was used in many ways by the most powerful men in society as a devoted lover, confidant, counsel, and friend. It was because of this that the women who successfully practiced the profession of courtesan acquired a high rank in Rome and Venice.

Coutesans played an important role in pieces of Renaissance society. They were individual women who created a world which, if success prevaled, enabled a woman to acquire financial and social independence. Several of the courtesans in Italy, particularly in Venice, became published poets as weil as tools for political and diplomatic affairs.

In the wond of the visual ats the countesan appears as herself, as well as in the guise of mythological figures. It has been said that the paintings of Palma Vecchio were

\footnotetext{
${ }^{04}$ Franco, V., Poems and Selected Letters. The University of Chicago Press, Chicago, 1998, 5 It is said that in Venice, fewer than four percent of women had acess to an education ton to twelve percent of Venetan women were literate, with an average of thing percent of men were literate. Whith this as a common average, and knowing that in order to be among the ranks of the Honest Courtesan, one needed to be versed in several languages including Latin, as well as versed in the poetry of the day. It is clear that a Venetian courtesan was among the most educated of persons in Italy
} 
simply portraits of courtesans." This is a fair assumption, but there needs to be an ex-

amination into who the women were which captured the imaginations and hearts of the

powerful men of sixteenth-century Rome and Venice.

Onc of the most famous Courtesans was the poctess Vcronica Franco. She made strides to establish a important status and respectability for the role of the Honest Courtesan, the highest rank of the profession in Venice. She possessed beauty. "grace, wit in conversation, and style, good judgment, and proficiency in many skills ${ }^{-9 \%}$ elements that would distinguish the Honest Courtesan fron the lower-ranked prostitute in Venice. The Honest Courtesan attempted to establishing herself as a respectable member of society and to ease the harsh and blatant hatred that was common towards the profession and the women who chose to practice it. ${ }^{97}$ Thomas Coryat, an Englishman who journeyed to Venice in 1608 to survey its legendary sights and women, wrote of the Honest Countesan.

"Moreover shee will endevour to enchaunt thee partly with her melodious notes that shee warbles out upon her lute. which shee fingers with as laudable a stroke as many men that are excellent professors in the noble science of musicke; and partly with that heart-tempting harmony of her voice Also thou wilt finde the Venetian Courtezan (if she be a selected woman indeede) a good Rhetorician, and a most elegant discourser, so that if shee

\footnotetext{
Rylands, Paima lecchio. 89. Rylands mentions that in an inventory of Paima's studio upon his death, a painting was listed which referred to the sitter in the portrait as "I retrato de la car.a con caveli butadi su le spale et vestida de verte meza facta de ca braza l' The reference of someone in Renaissance Venice as 'car.a' was an abbreviation for comompona, a name given to Venetian prostitutes who were required by law to hive in the area of $\mathrm{Ca}$ Rampani in the parish or Sañ Cassiano in 1421. Clearly the assumption by art historians that many of the sitters in the more provocative femaie portraits produced in the sixteenth century as being prostitutes or courtesans is a correct one

${ }^{\circ}$ Franco, Poemis. 12. Veronica Franco uses this list of qualifications for becoming a Cortigiana Onesta in a letter to a lady friend who consults Veronica on pimping her daughter for the profession of courtesan. Incidentally, Franco gives a reply to the mother which is surprising to scholars. She dissuades the mother fron forcing her daughter into the profession. Verunica stresses the risks associated whin the profession of courtesan, such as diseases and poverty, as well as a certain levei of financiai uncertainty, which lead, in many cases, to destitution and homelessness for the women who pursued the profession.

"Franco. V. Poems and Selected Letters. Ann Rosalind Jones \& Margaret F. Rosenthal eds., The University of Chicago Press, Chicago, 1n. An illustration of wit and morality demonstrated by Veronica Franco is evident in a letter which she wrote to a friend. Veronica, at one time, had given advice on how w face adversity. In reciprocation of the advice given, Franco uses her exemplary behavion and ability as a letter writer to demonstrate that although she held the occupation of a courtesan, she did not possess the disposition of the typical greedy, immoral prostitute. Equally important is how this letter must have made her to appear to an outside audience.
} 
cannot move thee with all these foresaid delights, shee will assay thy constancy with her Rhetoricall tongue.

What were the beliefs of a woman who was attempting to make the profession of courtesan legitimate? This is a poignant question particularly when long-held traditions conceming a women's place were spouted by social commentators such as Ludovico Dolce. His ideas conceming women in society resounded through the social traditions of Venice:

"...But in a woman one does not look for profound eloquence or subtle intelligence, or exquisite prudence, or talent for living, or administration of the republic or justice, or anything else except chastity. "*;

Aside from the sexist dictates heaved upon women in sixteenth-century Venice, a troubling matter concerning the courtesan in Venetian society was her autonomy and independence, qualities which appeared as blatantly as did her overt sexuality. In a novella by Francesco Pona entitled La lacerna, he describes the frecdom experienced by couriesans

"Froedom is the most precious gem a courtesan possesses and contains within itself everything she desires. Given the privilege, even infamy seems honorable to her. Since she is not subject to the iyrany of husbands on parents, she can deliver herself to her lovers without fear of being killed for reasons of honor. In this way she is free to express natural appetites and feminine lasciviousness."

Around the beginming of the sixteenth century approximately 10,000 cotutesans moved about Venice, which was ten percent of the population. ${ }^{10}$ Many famous and mowerful men were patrons to courtesans. The women who gave pleasure and compan-

\footnotetext{
"Coryat, T. Coryat's (rudities, Scolar Press, 1978, 267. Rosenthal uses this passage in her Honest Courtesan. 73

"Brown, P.F., Ant and Life in Renaisance lenice. Abrams, New York, 1997, 157

" Pona, F. la lucema. Salerno, Roma, $1973,109$.

"Brown, Ant ard Life. 157. Bruwn makes this statnent without any substatial note on the source obles than best estimates. This statistic must have taken in the women who were in all waks of iffe. it must include the women who were the respectable Honest Courtesans, to the individuals who periodically practiced prostituion to make financial ends.
} 
ionship at a very high price, lived unimaginably sumptuous lives thanks to the patronage of their wealthy and powerful clientele. There is evidence of the liaisons between the powerfui men of Europe with the courtesan in the visual arts of Renaissance Italy.

Agostino Chigi was a banker to kings and popes and a great patron of the arts and letters. He was also one of the wealthiest man in Europe and he adored beautiful courtesans. ${ }^{102}$ Chigi was famous for his sumptuous dinner parties in his Roman villa which hugged the Tiber river. He commissioned master draftsman and the painter Raphael to design a decorative scheme in his Villa Farnesina which celebrated the love between himself and his mistress, the courtesan Imperia." An entire decorative scheme of the villa was completed because of a Roman courtesan. ${ }^{104}$ From the partnership of patron and artist, as well as patron and courtesan, the world received the legendary Farnesina frescoes.

The frescoes depict the two lovers, Chigi and Imperia, seated at their marriage banquet accompanied by a joyous celebration with the gods. From this commission also came the lamous Galateu Fresco which depicts the sea nymph driving her chariot ${ }^{\text {ins }}$

Further examples of the powerful men who patronized the courtesans of Rome are Julius II, who eniertained the famous courtesan Masina before his succession to the papacy. ${ }^{116}$ Other men in positions of power, such as Angelo Colocci and Biagio Pallai, secretaries to popes, held garden parties and gave suppers to which many courtesans were invited. ${ }^{i t}$ The opulent evenings designed to entertain the famous courtesans of Rome with their adoring patrons as host is described by Lawner:

\footnotetext{
mid., 37.

1 inid., 37.

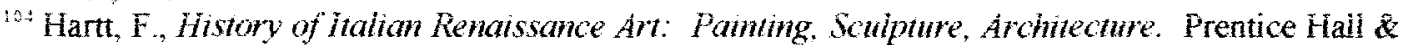
Abrams, New York, 1994, 528.

${ }^{195}$ Hartt, History. 530. According to Hartt, Raphael had no intention of depicting the courtesan Imperia as Galatea. Lawner contends that Imperia was depicted by Raphael as Galatea driving her chariot. It is also assumed that Chigi and Imperia are shown at their wedding feast with the gods in attendance, as seen in the Wedding Banguet from the Loggia of Capid and Psyche, from the school of Raphael. See Lawner, Lives, 37 .

Lawner,L., Lives of the Courtesans. Rizzoli, New York, 1987, 35.

in? Ibid., 36.
} 
"When not promoting their careers, these men spent their time writing nostaigic Latin verses and imagining that they were still living in the time of the Circus Maximus, the Forum, and the formidable hetacra of old."

In Venice, an imporiant relationship between a powerful man and a courtesan existed between Domenico Venier and courtesan Veronica Franco. Venicr was a former Venetian senator and member of a distinguished patrician family in Venice. ${ }^{109}$ He was an influential personality in Venice who counseled, supported, and published the works of female writers and poets such as Tuliia Aragona and Moderata Fonte, as well as Veronica Franco. ${ }^{10}$ Franco, described as a sixtenth-century Diotima, ${ }^{111}$ was an intellectual courtesan who was also a socially conscious poetess who wrote numerous verses of prose on many subjects. How Franco came to be in the counsel of Domenico is not known, but their relationship lasted for a decade. ${ }^{i 2}$ Through their ten-year relationship, Veronica was honoted with the freedom to grace the threshold of Venier's literary salon in Ventee, the gathering place of the foremost intellectuals and writers during sixteenth-century Venice." Veronica Franco is one of the most famous of courtesans from the sixteenth century. She was not only famous for her clientele. ${ }^{\text {iif }}$ but was acutely aware that her sex was greatly mistreated. Veronica's strides towards achieving respect and high social status for

\footnotetext{
105 Ibid, 36

in" Franco, foems , 1

: Lawner, Lives. 57

"Ibid., 127. Diotima was a woman from Greek myth who is said to have had a long conversation with Socrates on the true natures of Eros. Diotima is sketched as a very intelligent woman who convinces the great and wise Sorrates that Eros is not good or beautiful, nor bad and ugly, but in nature lies somewhere between the two. See Morford and Lenardon's book on Classical Mythology, 3rd ed. 133-136.

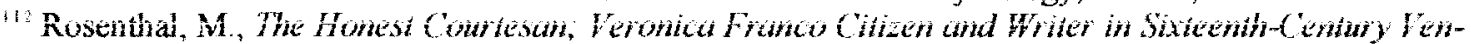
ice. The University of Chicago Press, Chicago, 89.

$" 1$ Franco, Poems. 5. Domenico Venier was a patron to other women writers besides Veronica Franco. He sponsored and published works from Tullia d'Aragona and Moderata Fonte. Venier's salon boasted members who were the elite of Venice. She frequently requested sonnets and poems to commernorate members of the Venetian elite, such as Estore Matinengo, a military hero who died in 1575

"Lawner, LWes, 58 . Th the summer of 1574 venice was visited by Heny of Valois, who was traveling to Poland to be crowned Kind Henry III of France. While in Venice, Henry visited Franco's boudoir. After his departure, Veronica presented him with a miniature portrait of herself, along with love poetry addressed to him
} 
the status of her profession are apparent in her attempts to legitimize the profession of

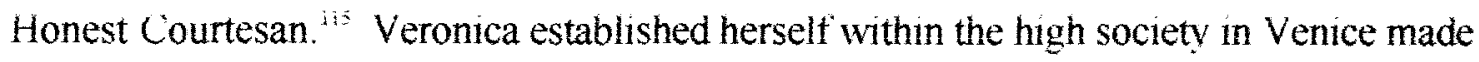

predominately of men. Some of these strides are evident in her patronage of the wealihy and powcrul morchants and ambassadors who passcd through the city. ${ }^{116}$

Veronica's progress for respect in her profession is evident in her poetry which speaks in a defiant manner, that communicates awareness and sympathy for the fairer sex." She repeatedly defended herseif against the misogyny that haunted the minds of even the most cnthusiastic Mumanists. Veronica's literary works express an open sexuality and eroticism that had never been seen before in the poetry of her sister poets and

\footnotetext{
"Rosenthal, The Honest. 77. One of Veronica's wills states that she wished for capital from her investments to be given (if her mother was deceased) to the dowry balloting systen of the six guardians of the Scuole Grandi. The dowry bafioting system enabled runds to be avaliabie for members who coutd not alford a substantial dowry for their daughter. The increasing price of the dowry was a significant probiem in Venice. The cost of an acceptable dowry rose to such great heights that very few Venetian families could afford to respectfully marry their daughters into annther family This then forced two chnices unon the daughters of Venice: to become a courtesan or to enter a convent.

"Tranco, Foens. 32. A wondertul cxample of Veronica's charm is evident in a friendy inviation to an informal meal at her house: "Among the many favors $I$ could receive through your kindness, the best of all will be that you do me the favor of enjoying some pleasant conversation today, along with your friend, who will be very eager to come. You see how this rainy weather invites all good folk to settle down inside by the fire at least until evening If you're willing to come we can partake in mutual comfort, sine

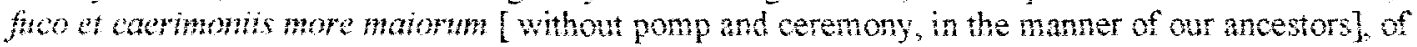
Whatever food therell be. And if you'd be so kind as to add a hithe hash of that good namimsey of yours, am content and ask nothing more. This evening, then. Thi obey your order, a delight to me, to go to your friend's house. And whatever you choose to do, for my part, I'll always behave most lovingly toward you".

1" Franco, Poms, 245-256. In her Tora Rima, Capitolo 24, Veronica defends a woman who has been insuled by a man. Her words are guick to strike at male weaknesses, and asserts that women would be superior to men if given the chance: ".. Look with the eyes of your good sense and see for yoursellhow whworthy of you it is to insult and injure women. Unfortunate sex, always led about by cruel fortune, because you are always subjected and without freedom! But this is certainly been no fault of ours, because, if we are not as strong as men, like men we have a mind and intellect. And virtue does not lie in bodily strength but in the vigor of the soul and mind, through which all things come to be known. and I an certain that in this respect wonen lack whing, but, wher, have given note than one sign of bensts greater than men. But if you think us inferior to you, perhaps it's because in nodesty and wisdom we are more adept and better than you.... And so we women, who are wiser than you, to avoid contention, carry you on our backs as the surest of foot carry those prone to fall. But most men do wrong in this matter; and woman, to avoid pursuing wrongdoing, adapts and endures being a vassal."
} 

not only friends, but prospective lovers. "1!

Thesc were some of the strategic actions taken through her carcer as Venice's Honest Courtesan. They were actions that constituted a level of respect for the profession, further enabling the courtesan to move in high society.

$\dot{*} \quad \dot{*} \quad \dot{*} \quad \dot{\pi} \quad \dot{x}$

\footnotetext{
"18id. 69. The following excerpt is from Franco's Terza Rima, Capilolo ll verses $149-178$. Some of these excerpts are also used in Mary Rogers' article "Fashioning Identities Tor the Renaissance Coute$\operatorname{san}^{*}$, Fashiming Idenibes in Renaisance Art. Ashgate, 2000, 97 . Veronica asserts a frankiy erouc identity with Venus in the following excerpts from one of her poems: "Sweetly lying at your left side, 1 will make you taste the delights of love when they have been expertiy learned; And doing this, I could give you such pleasure that you could say you were fully content and at once fall more deeply in love fo sweet and delicious do I become, when I am in bed with a man who, I sense, loves and enioys me, that the pleasure 1 bring excels all delight, so the knot of love, however tight it secmed before, is tied tighter still. Phoebus, who serves the goddess of love, and obtains from her as a sweet reward what biesses him far more than being a god, comes from her to reveal to mind the positions Venus assumes with him when she holds him in sweet embraces; so that 1, well taught in such matters, know how to perform so well in bed that this art exceds Apollo's by far and my singing and writing are both forgotten by the man who experiences me in this way, which Venus reveals to people who serve her. If your coul is vanguished by love for me, arange to have me in far swecter fashon than anything my pen can declare Your valor is the steadiast knot that can pull me to your lap, joined to you more tightly than a nall in hard wood; your skill can make you master of my life, for which you show so much love - that skill that miraculously stands out in you."

"1" Franco, poems. 32 . In a letter to a young man, Veronica educates him on the fact that intellectuals win her affection, She cites Socrates from The Symposim, while also flattering the young man and buting

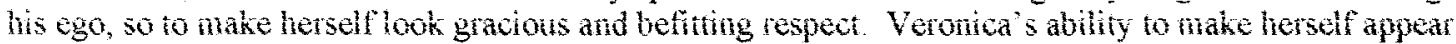
gracious while also easing egos of the men who surrounded her is a characteristic which would have placed her in the interests of the noble men of Venice. She never appeared to slight a man without good reason ... but turning to instead to our subject of love. there's no doubt that it acts as a stimulus in us. which, depending on how it's shaned by our feelings, is the source of opposite things... And for this reason, the wise man said that to assemble an army that would be undefeated and always victorious, it should be made up of men who respect lowng and being loved by each other.. And you know full well that of all the men who count on being able to win my love, the ones dearest to me are those who work in the practice of the liberal arts and disciplines, of which $I$ am so fond. And it's with great delight that I talk with those who know. so as to have further chances to leam. for if my fate allowed. Ii would happily spend my entire life and pass all my time in the academies of talented men. This could be a great advantage to you, being industrous, as you are, in fine wring and in the flower of your youth, which if you nourish and chlivate it well, will bea fruil to you perpetul prase and fane in the opinion of every wise and experienced person. Take advantage of these capacities, attend to your studies, and by living a settled life in the tranquility of study and showing me the profit you gain from honest learning rather than any of the world's goods, you could lead me to love and cherish you.
} 
The ancient Greeks used the term hetama, or the Latin version hetaora, ${ }^{120}$ which encompassed the profession of the original courtesan, dating to the fourth century. $B . C_{2}$ Heharae were unwed women who were sexual pariners to wealthy and powerhil men." Known to be intelligen, savy companions, they wcre capable of bcing cverything a common prostitute was not. Hetagras were known to perform privately as entertainers and were lively conversationalists who graced dinner parties of wealthy and powerful men in ancient Greece, ${ }^{23}$ In ancient Athens, as in Venice, different levels of prostitutes existed which denoted different levels of prostitute. All women who liva the lifestyle of prostitute were reterred to as hetwera regardless of their social rank in the profession. ${ }^{124}$ It is known that in classical theater the hetaerae were identified as fictive characters who were part goddess, part human being. This classical model, which placed the hetearae into the guise of my hological higure, inspired antists and witers of the lalian Renaissance.

The Renaissance desire to achieve all things of the classical world affected their at titude towards the courtesan. The guise of mythological goddess temptress or nymph, was common for the courtesan in sixteenth-century paintings. She was illustrated in the visual arts, and in stories from antiquity which involved the beautiful and sometimes troublesome goddesses of classical mythology

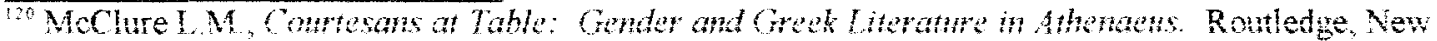
York, 2003 , xi. Mechere explans in the ntroductom that she used Latized version of Greck thes and names. The Greek piural for prostitute is hetwirai. I will be using the Latinized piurai hetaerae thetera is singular)

11 Ibid.. 1.

$122 \mathrm{http} / \mathrm{w}$ ww bookrags com/hiography/Aspasia/, Biogrophy of Asqusio. The second wife of the emperor and general Pericles was Aspasia, countesan of non-A thenian bith. Aspasia was bon into a literate family in Miletu, the sonthemost fonian chy and greatest netropolis in Asia Ninor. She was the devoted wife of Pericles, who drew scholars, artists, scientists statesmen, and intellectuals to discuss current events, literature, and philosophy. It was said that Pericles trusted her advice more than any of his political advisors. ${ }^{23}$ McClure L.M. Courtesans at Table. 108.

"McClure, Courtesans. 15. The Greek term nome originally dennted a brothel slave and is often distinguthed from the hatar by the number and anonymy of her parners, as woll as by the fact that she

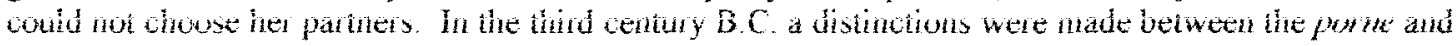
the hetara. The cultured courtesan, in both ancient $k$ thens and in Renaissance Venice, possessed the freedom to choose her partners. There was a distinct difference between the levels of prostitute in ancient Athens. which was transferred to the Renaissance version of the courtesan, particularly in Venice
} 
Flora was, according to classical mythology, the goddess of flowering and ripening of grain vines. In the (jvid, she is the companion of Zephyrus the West Wind who, atter a violent abduction, gave her a garden flled with flowers."?

Fabricating Flora into a harlot came about in Roman antiquity. ${ }^{\text {in }}$ The name of tho Roman goddess who makes all things grow, was used by several great artists of the Italian Renaissance. Palma's Flora (Fig. 12) is widely acclaimed as being one of the most elegant and beautiful of depictions of Flora. One needs to ask, in reference to Palma's Flora, did he wish for the viewer to see the sitier as Flora the courtesan or Flora the goduess? With her blonde tresses falling freely over her bared shoulders, her entire appearance is a personal invitation for the viewer to taste her delights. The small bouquet she holds is the only indication of a representation of the illustrious goddess. The direct gaze of the blonde beauty is an indication of the sitter's chosen profession, as well as the bared breast which is shown particular attention by the blue ribbon loosely draped beneath it. The deliberate exposure of her supple white skin beneath her camicia ${ }^{27}$ is another indication that this is not a simple personification of liora, but a woman who chose such a guise for her profession as courtesan.

Titian's Ilora (Fig. 13) glances off to the side of the picture plain, not directly at

\footnotetext{
Ts. Morford, P. \& Lenardon, R.J, Classical Mytholog; 3Fd editon. Longman, London, 473

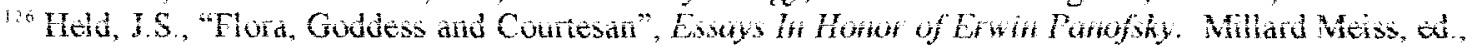
vol. 1, New York University Press, 1961, 109. Heid uses the reference to Flora from Boccaccios Genealogie Deormm Gentilium Libri. Boccaccio received the inspiration for making Hlora into a harlot when reading about a Roman prostitute who. in her will, left money for games to be held in her honor upon her death Naturally, the Roman Senate was appalled by this act of philanthrony in the hands and name of a hatot. A man tamed Lactantius is said to have recorded the shome folt by the poman senate upon learning of the procedings of the prostitute Fiva.

Mellencamp, E.H., "A Note on the Costume of Titian's Flora", The An Buhlom, v. 51 (June 1969), 174. The camicia was a full-length garment which was always sleeved, and always fell from the neckline It was thought to be the apparel of the wedding night.
} 
the viewer as the sitter does in Palma's composition. Although she is a phenomenal beauty, as her copper trosses drape over her partially bare shoulders, one porectives that she is striving to retain her modesty. A biatant advertisement of her easiness is not evident as in Palma's Flora.

Paris Bordone's Flora, (Fig. 14) another bare breasted beauty immortalized in paint, does not glance directly at the viewer either, as in Thian s compusition. Sithing in an architectural setting. Flora holds loose flower petals in her right hand. indicating her identity. An almost indifferent look upon the sitter's face expresses a sadness and a longing to be elsewhere. Bordone's display is completely difforent fiom the arousing image on Paima's canvas. Paima s flora exudes an open eroticism which is not seen in either nainting by Titian or Bordone

Depictions of Flora by Titian and Bordone present a partially nude woman on the canvas, yet their expressions do not entice the viewer to connect in an intimate manner as we see in Palma's Flora.

Leda, the daughter of a King of Aetolia and the wife of a Spartan King is another my thological character given the profession of courtesan. Her union wh Jupiter, who seduced her in guse of a swan, places a woman in the throws of passion with a non-human character. In the visual arts the union between a woman and the swan have been depictcd in ways which arc not only as crotic but disturbing, as sccn in Raimondi's crigrating of the myth. (Fig. 16) 
claborate boudoir. Leda's opulent hair and jowclny arc an indication of Veroncs's intentions to present $i$ eda as a courtesan. Lawner suggests that "Surely leda knows that her unusual partner is, in reality, a roval guest. Leda appears in control of the situation so the swan no longer appears as a formidable divine force, but rather an affectionate pet." The fis observer of the painting would have been fully awafe that such a union, one between a beautiful woman and a royal deity, housed contemporary connections. It was no secret that the courtesans who moved within the most powerful social circles, entertained the wealthest of merchants, statesmen, and in the case of Veronica $\Gamma$ ranco, royalty.

Leda, the beautiful woman seduced by a deity disguised as a swan on the Euphrates River Bank one day, bears a striking resemhlance to a courtesan who allowed herself to be seduced by any number of powerful men.

Danae is a very common figure from ciassical mythology who is depicted quite frequently in the Renaissance. Painted many times by Titian for Philip II of Spain, Danae is a strong connection with the world of the Venetian courtesan. The myth of Danae tells the siory of a virgin who was seduced by Zeus disguised as a shower of gold. A level of ambiguity in the story dwells in the question of whether or not Danae gave herself willingly to Zeus. Was she tempted by the sight of the gold dust which fell from the heavcns? The answor to this question was duly illustrated numcrous ways by Vonctian artists.

Lawner. Lives. 106 
ment wher 7 cus visits her in the shower of gold, could be vicwed as an outline for the progression of the Danae from an imocent virgin who was locked away by her paranoid father, into Danae, the venal, insidious woman who sold her virginity for a shower of gold coins. Numerous artists have depicted Danae as the pure, innocent girl waiting for the shower to reign down upon her, such as the paining by Gossamer. The opposite side of the spectrum in the depiction of the Danae myth is duly illustrated by Giulio Bonasone. who left nothing to the imagination in his engraved depiction of the moment before the mion. (Fig. 18)

Vemus is perhaps the most common and well-known of the mythological characters in the guise of the sixteenti-centuiy countesan. She is rendered hundeds of thes as the goddess of love and beauty with her son Cupid at her side. Venus was first viewed in the nosition of courtesan as written by Boccaccio in his Famms Women In Boccaccio's eyes, Venus was the daughter of two mortals with no known roval lineage. She was simpiy placed upon a pedestal for her outstanding beauty ${ }^{124}$ of which Boccaccio speaks.

Indeed. Venus radiated such beauty in her face and her entire body that often those who saw her could hardly believe it. Some said that she was the very star we call Venus. Others believed that she was a celestial being who had fallen to earth from the lap of Jupiter. ${ }^{\text {in: }}$

The unrequited beauty of Venus did not keep her from the shame of two hushands. Boccaccio claimed that through her shame she "devised something that was abominably foul. Venus was the first, so they say, to estabish pubic prostitution by setting up brothels

\footnotetext{
${ }^{2 y}$ Boccaccio, Famous. 39.

133 Ibid.. 41.
} 
and forcing married women to enter them "ist

The association between venus, the goddess of beauty and love with the courteSan is very imporiant when viewing the rechned nude in sixteenth-century at. Giorglone

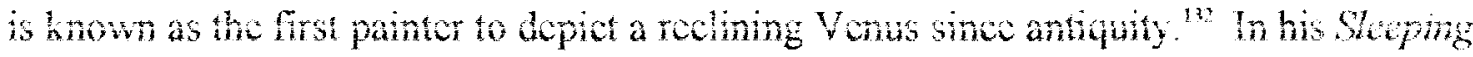
Vents (Fig 19) the goddess of love slumbers in a pastoral setting with hills in the background mirroring the contours of her body. Devoid of a figure of Cupid. ${ }^{\text {st }}$ this sleeping beaury is any man's dream of a beautifui nude woman slumbering in the countryside, unaware of hor suroundings or vicwers. Sumptuous bodelothes bencath her hint of a possible tyst whoh is to take place; prhane Venus is watting for an elustve lover, and has fallen into a peaceful slumber. An explanation of the landscape setting in which Venus is reclined, is a realization that the Renaissance man may have looked upon this image and seen one thing. that as the land is for use by man, so is woman.

Titian's Vom of lobino (Fig 20) is a reclining beaty commonly deemed a cour tesan. A composition which followed the unveiling of Giorgione's Sleening lenw by thrty years, hitian s Venus rechnes inside an elaborate boudorr who appears to be awaiting a patron, a rote which the viewer could assume. Venus' intense, seuductive gaze, which penetrates the picture plane, is enough to enrapture a viewer to the point of obsession. This is a seemingly nefarious quality of Venus and the Venetian courtesan. And just as in Giorglone's Sleeping Venus. Titian's Venus of Urbino is completely devold of a Cupid Iigure. There is no connection with the mythological character Venus. It seems as if the

\footnotetext{
ioid., 43

$\therefore$ Anderson, 1., Giongione: The Painter of 'Poetic Brevity'. Flammanon, Paris, 1996, 223. A cameo depicting a recining Venus with a Cupid suspended above, is a consummate example of the visual inspiration needed to revive the claccical reclining Venus and her michievars con

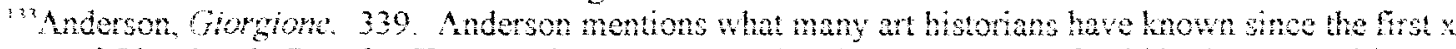

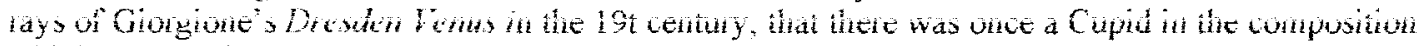
which was hoiding a tiny bird clasped by its legs. Many different expianations have been ofiered to the reason behind the obscunty of the Cupid figure. It is believed that Titian actually finished the panting, which was ieft unfinished upon the early death of Giorgione in 1510
} 
contemporary theme surrounding images of Venus, transformed into an understanding that the Venetian courtesan possessed the qualities of Venus. Just as the goddess of love could beguile any man who looked upon her, ${ }^{17}$ so could the courtesan.

Images of Venus, which followed those by Giorgione and Titan, prolferate in the annals of art history. A reclining Venus by Bernardino Licino is the epitome of Venus as courtesan. The canvas illustrates a reclining beauty in a very private boudoir, wearing nothing. Venus, who lies in a seductiveiy erotic posture in the foreground of the composition, forces the vicwer to look upon the nude woman, who appears to be watting for someone. The realistic quality of the figure is one element which would beguile any man to look upon the image an wish to be Venus' partner. Once again, there is no figure of Cupid, yet the reclining nude continues to be given the name of the Roman godidess of love and beauty.

The concept of the mistress or courtesan as a model in portraiture was very com mon in ancient Rome and Greece. Throughout antiquity, monumental statues and sculptures were erected in honor of particular courtesans. This is yet another reference to the classical ideal which Renassance man strove to assume.

There was Leaena, a courtesan who was dear to Boccaccio in his Famowis Women, who defended her lover by mutilating herself. She was tortured in attempts to retrieve information needed to sentence her lover to death. Leanena's unwillingness to betray her lover, resulted in her biting off her own tongue, rendering herselif unable to speak. ${ }^{154}$ The Athenians, desing to honor Leaena's heroism, crected a bronze statue of a tongue less li-

\footnotetext{
Fiero, G., The Humanistic Tradition From Romanticism to Realism in the Western World. Willian $\mathrm{C}$ Brown Comm.. Dubuque. IA. 1992, 85. Manet's Olympia , painted in 1863, caused an uproar because it was thought to have debased a traditinnal subiect Modeled after Titian's Vems of llmim little is left to the imagination as we receive a languid gaze from olympia, who redines between clients while receing howers fron a doting pation. The simianites are easily detemined between the sixieenth-century venus and the nineteenth-century Venus (do we dare cail Olympia Venus?). See aiso Kona Goffen's Than s $V t-$ mus of Urbino, Cambridge U. Press, U.K., 1997, 4.

${ }^{135}$ Boccaccio. Famous. 205.
} 
oness in the Propylaea on the Acropolis ${ }^{136}$

There was Theodora, wite of the Emperor Justinian, known to be a venal, intelligeni and beautiful prostituie, ${ }^{* 7}$ was transformed into the noble wife of the emperor of the Roman world during the sixth contury. She is portraycd in mosaic on the walls of San $V$ tale in Ravenna, Italy. Theordora will forever wear the color of royalty

Phryne, the mistress of Praxiteles. was immortalized in marble as the Aphrodite of Cnidus at her bath. "Phryne as Apinrodite is the personification of the Greek tradition of love. It was Praxitcles who camo to be hown as the grcatest scuptor in ancicnt Grode ${ }^{39}$ because, in part, of the work inspired by his mistress.

Lastly, the story of Alexander the Great and Campasne is another instance from antiquity of mistress and powerful ruler. References of a painting of Campaspe commissioned by Alexander, appears many thres in Renaissance texts. The story of the panter Apelles, who executed the portrait of Campaspe is as follows:

"The magnitude of Apelles' genius was significantly demonstrated by his painting of a beautiful woman, that is his nude portrait of Alexander"s mistress, Campaspe. Seeing the beauty of the portrait, Alexander saw that the artist appreciated her (and loved her) more than he. And so Alexander 'paid' for the portiait by presonting Campaspe to Apelles."

According to this ancient story, whomever could est depict a beautiful woman deserved to have her. Wo could say that this view is indincely rellected in Renaissance man. The mode of female possession was transferred to acquiring an image of her. ${ }^{31}$

\footnotetext{
Sot Lower, Lhes, 83

Kieiner, F, Mamiya, C, Tansey, R., Garaher's Ant Through the Ages: the Westem Perspective, itin edition. Thomas Wadsworth, U.S.A., 2003, 268.

13: Ibid. 84

i30 Kleiner, Mamiya \& Tansey, Cardne' 's. 139 . Praxiteles hrought the human element to sculnture which lookd as if they breathed and carried life. He was known as the greatert soulptor from the Hellenis ic period and was later a evered in the halian Renaisance.

: Pliny the Elder, Naturai History. Engiish Transiation by H. Rackham, Cambridge University Press, Cambridge, 1949, 79-97.

${ }^{14}$ Goffen. R. Titian's Women. Yale University Press. New Haven. 1997. 9
} 
sixteenth-century Venice.(Fig. 21 ) Upon seeng the mage which Tintoretto produced on the canvas, Veronica"s disbelief and amazement is stated in her leter to the arist:

"...Among the other things that cause them to praise the ancicnts to the skies, they include painting, sculpturing, and working in relief, and based on I do not know what, they deciare that nowhere in the world is there to be foumd anyone who attains the excellence of Apelles, Zeuxis, Phydias, Praxiteles, and other noble and famous painters of those days... 1 promise you that when $I$ saw my portait, the work of your divine hand, I wondered for quite some the whether it was a painting of a ghost that had appeared before me because of some diabolical inck."

Veronica Franco's words illustrate a depiction of a courtesan in a visual context with no imptications of idealization of the sitter. The relationship between Franco and Tintoretto was not one of a mistress and her master, but patron, sitter and painter. The power of the painted image which is Veronica Franco as herself conjured exaltations which harken to classical antiquity. It exemplities the importance of the painted image of the courtesan in the sixteenth century. Within the portrait of Veronica Franco by Thitoretto lies evidence that portraits were executed of women who were courtesans, not just idealizations of female beauty

The courtesan in ancient art is followed many centuries later in the ambiguous female portaits prevalent in sixteenth-century Venetian art. Paima Vecchio's oeuvre of wenty unnamed female portraits contain all the aforementioned elements of the Venetian courtesan.

Portrait of a Woman with a Bared Breast (Fig. 22) is a composition that carries all of the implications denoting the sitter as a courtesan. The trianguiar composition which places the sitter in the foreground of an faint architectural setting is similar to most of Palma's women. This blonde beauty, whose hair falls freely onto her shoulders, clenches Rosenthal. The Honest. 248. 
her garment while exposing her bare breast to the viewer The lady heholds the beholder

with a provocative side glance. beckoning a conversation with the viewer, perhaps with a sharp-wited quote. She possesses inteligence in her eyes, offering herself to whomever is cnjoying he company. Maybo our voluptuous sitter prepares an invitaton son to bo uttered from her lips. She is the epitome of ideal beauty in the poetic tradition of the courtesan who frequented Venice.

Paima's Woman whit a Bared Breas is similar to the composition of ia FarFumina (Tig. 23) Raphacl produced a dark beaty with both of her brasts barcd to the vewer who stares intently of the side of the canvas, avoiding a direct gara with the viewer. La Fornarina is a blatant display of a willing courtesan or mistress posing for the viewer with a coy smirk upon her delicate lips. Paima's lady possesses a more serious expression which doesii i necessanily employ a look of sincere provocation, but more of a need to converse or relate to her viewrer. In her eyes inhabit an intensity which most sixteenth-century painters did not achieve from their sitters be they courtesans, or a beauty from the painter's imagination.

The intensity and intellect apparent in Pama's Woman wh a Bared Breast is seen most heenly in Palma's Woman in Plack(Fig. 24) Atributed to Palma sinca 1720 this composition has been thought to be a work of Titian in recent years. ${ }^{\text {Hs }}$ The woman in black holds an intense gaze which possesses an intellectuality akin to the gaze from Palma's Woman with Bared breast. Her observant gaze is directed at her audience, with a glow of humanity in her yes while she watches her viewers with as much fervor as ate is receiving from her audience. Surveying her dress, posture and unadorned beauty, it is clear that she is hikely a courtesan by profession. Her camicia drapes off her shoulders.

\footnotetext{
Ryiands, Paima Veccho. $31 \mathrm{I}$. Kyiands makes this assessment on a ciose examination of the handing of the paint. The free treatment of the lights in the complex folds of the black sleeve indicate is an indicator that this was not the handiwork of Palma Vecchio, but Titian.
} 
nearly exposing her hreasts, while her golden tresses fall wer her smooth skin and down her back.

A final work of Paima's to examine is a peculiar paining eniitied Fortrait of $a$

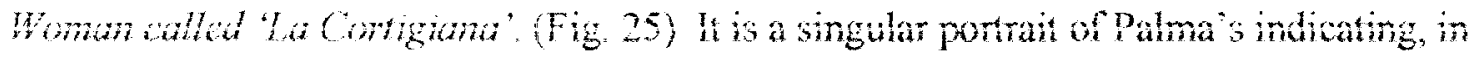
the title, to be an image of a courtesan. A vision of an elaborately dressed woman with both of her breasts bared fits the prototype for the traditional courtesan portrait. But the depiction of this woman is divergent from Faima"s other paintings. Her ethereal, giassy appearance cnds a goncric identity to the sitter. The cxceution of the woman, particum larly in the lace, is modem in comparison to what was produced in sixteenth-century Venetian painting. She does not possess any signs of outward interest in the viewer as in Paima's Woman whin a Bared Breast and Woman $m$ Biack, where both interact intimately whth the vewer. Her elongated hose, petite mouth and fawess skin, which cover hondescript shoulders, lend to the peculiarity of the painting. It appears as if Palma conjured the sitter on the canvas from his imagination Could this be how Palma believed a beantiful courtesan would appear? Living in Venice for most of his aduit hife ${ }^{i: 3}$, he would have been fammar with the Venctian coutesan in her appealanes, mametisms, and whes. Regardloss, La Cortigiand is the singular painting that leaves no question concerning who the woman within the frame was purnorted to represent

The courtesan in stxteenth-century art encompasses a complicated and fascinatung character who ived her iife apari from the conines of iraditionai patriarchy and misogynist thought. The world of the visual arts indulged the courtcsan beginning in antiquity. The ambiguity of who the courtesan was, followed by her overt sevuality and independence, is a fresh subject matter that will always be desirable and sexy. There lives an in-

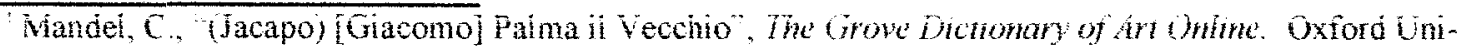
versity Press, Accessed March 30, 2004, http.//www groveartcom. Palma's dates are c. 1479-1528. By 1520 he was living and working in Venice where he spent the rest of his life.
} 
triguing person behind the paint and canvas, with a story to tell that is her own

In the case of Palma Vecchio s female portraits Violante, Woman with a Bared

Breas, Wuman in Black, and La Corigiana, the mystery confined to the ladies who gaze from the canvas, never cases to intrigue the vicwer. Similar questions will continue to occupy future spectators: who was the courtesan of the sixteenth century? How did she come to practice the singular profession which enabled women of the Italian Renaissance to acquire freedom not ailotted the fairer sex until the twentieth century? 


\section{CHAPTER IV - CONCLUSION}

The fenale portaiture, a singular object that evolved from what was once an thustrated document of a woman's social status and obligation to her family into a declaration of herself or a type of female beauty, has heen thoroughly discussed in this paner The early notions of the female portrait had nothing do with her sensual character or her desirable nature. This element of fenale nature was overty concealed behind a vell to be witnessed only by the man who agreed to marry the woman in the profle.

Yet there are images, such as Palma's twenty female portraits, that served as types of ideal feminine beauty. They are said to be able to "invite a sensuous response through the use of ciothes and jewels and through the direction of the gaze. This at times evades the viewer's eye through painting techniques which explore the rendering of the softnes and luminosity of skin and hair, the richness of color and of different textures "145 Different portrait types were adapted for specific patrons, as illustrated in Palma's series of twenty such paintings. Connections made between the rising population of single men and women of sixteenth-century Venice are said to have been due in part to the crotic nature of female representation in Venetian female portraiture. $1{ }^{16}$ This differs greatly from the traditional female representation as seen in the painter's work of the fifteenth-century protile portrait.

What was the uhimate function of the female portiats produced by Pama Vec-

\footnotetext{
"Herlihy, D. "Polpulazione e stuture sociali dal XV al XVI secolo", Tiziano e Tenetia. Convegno In-

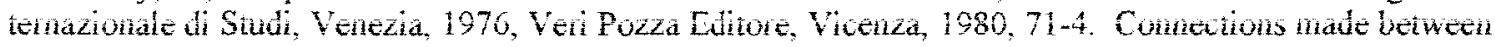
the rising population of singie men as weil as single women sixteenth-century Venice are said to have been due, in part, to the erotic nature of female representation in Venetian female portraiture.

${ }^{146}$ Ibid 73
} 
chio during the sixteenth-century? According to Paola Tinagli, the central theme in Italian Renaissance painting was specific to the female form. Well-born men and women were necessarily beautiful, and the need to give visual form to the lype of female beauty described by pocts resulted in new genres. Half-figure ropresentations of idealized women, and the redefined artistic techniques developed to convey the qualities of female beauty. ${ }^{17}$ This is true. though the answer to this question is more complex than expected. involving salacious societal mores in a cuiture that birthed a kind of sexual economy. The sexual conomy was fuclod by two notivating factors paiting and pootry. Pootic lisconso fueled the paintings produced by the artistic elite such as Palma Veccho, Titian, and Paris Bordone. Poets, in turn, such as Agnolo Firenzuola, Federingo Luigini, and Giangiorgio Trissino, created an ideal of beauty that embodied a desirable woman. She was then identhied as the woman who practiced the profession of coutesan, maning her an accessible tool for fantastical fulfillment.

The institution of the courtesan, educating women in the classics, poetry, and high societal manners, existed in a form not seen since antiquity. Classical references appeared in many foms in sixteenth-century paintings in Venice, particulany those eluaing to certain mythological goddesses taking on the profession. The courtesan was the clegant, liberal, and beautiful woman whom every wealthy man wished access of While many men who frequented the charms of the courtesan also possessed wives the expectations The nobile wives dwelled in a world of domesticity and child bearing.

One must wonder if the noble women's thoughts indeed paralleled what the poets were writing and the painters were painting. How did the wives of the men who were the main supporters of this so-called sexual economy view their place in society? Gaspara Stampa ciearly expressed the answer to this question in one of her poems. Her writing 
calls for artists to convey the interior life of the noble woman, as well as the clash of feel-

ings which confronted her everyday. Stampa imparts the distress telt by the noble women of venice in knowing that oiher women loved ineir husbands:

"You artist, who are able to rulect in marble, brone, and colours, or in was, a lifelike form precisely like the true one, even surpassing that which nature made; come all together in a gracious growp to shape the farest creature the First Care ever produced, since in creation's time with His own hands, he formed Adam and Eve. Portray my count, and keep it well in mind to show the inward man as well as outer, that your portrayal may be lacking nothing. Take special care to show his double heart - as you well see he has just such a one: his own and mine. givon to him by Love.

Then paint from the other side, just as you see me, as I truly am, alive without a soul, breast without heart, by an unheard of miracle of Love. And like a ship that moves without its rigging, lacking a rudder, lacking main - or foremast, gazing forever on the biest Nonth Star that guides the ship wherever it may go. And then observe that on the left-hand side my countenance is always sad and woefu!, but on the right is joyful and triumphant. My happy side has oniy this one meaning: that I an standing close beside my Lord; the sad fear, that another woman holds him.

Neither the presence nor the influences of a sexual economy were have been a secret. even to the chaste wives of Venice. Paintings such as Palma's female portraits would have hung in the homes of the wealthy men, perhaps in bed chambers, as celebrations of fortlityand marriage, or as nude mythological figures who gave their blessing of progeny upon the marriage union.

What was Palma Vecchio's ultimate intent within his unidentified female portraits? A possible answer appears in a discussion conceming Titian's intent for his nameloss beauties. Knowing that Titian was a contemporary of Palma, one may assume that the wo painters would have conversed about the enigmatic subject of ideal feminine

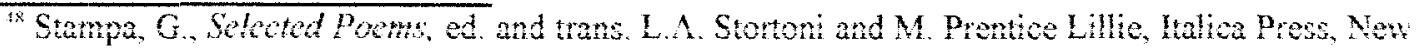

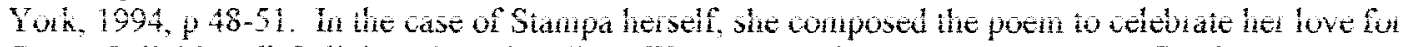
Coun Coliatino di Collatto. See Tinagii, $\vec{P}$, Women in Itailan Renaissance Ant: Gender Representanon identity. Manchester University Press, Manchester, 1997, 188.

is Tinagli. Women. 188.
} 
heauty Goffen claims that Titian identified some of his paintines of women as povere or

favole. He intended to evoke literature and antiquity in his female portraiture, not pornography, such as modem historians have clamed. Evidence of this lies in the fact that

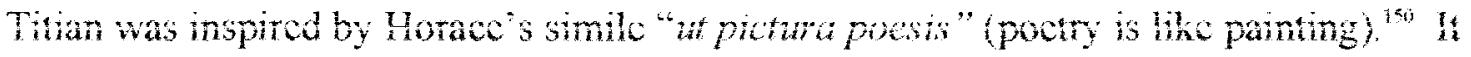
is a viable chim that Palma also evoked literature in his paintings, enabling his women to become comprehensible creatures in relation to sixteenth-century Vence. The external motivators for his paintings are clear when one examines the poetry and the institution of the coutesan. Thercin lay an accurate explanation of the paintings produced and the nom lyating factors which enabled Vence's sexual conomy to exist.

Not surprisingly, the issue of the male gaze prevails in this genre of painting Since we veiwed Leonardo's Gmevra de' Benc, which permitted the sitter in the portrait to gaee back from the canvas at the viewer, a catalyst was created which spumed a cutture of seeing.

The cultural pillar that traveled from the sixteenth into the twenty-first century is best described by a postmodern art critic.

"To be bom a woman is to be bom whin an aloted and conned space into the keping of men. The social presence of women has developed as a result of their ingenuity in living under such tutelage within such a limited space. But this has been at the cost of a woman's sellbeing split into wo. A woman must continually watch herself. She is almost continually accompanied by her own image. Whis she is wakng awoss a room, or whis she is weoping at he duth of her father, she can scarcely avoid envisaging herself walking or weeping. From eariest childhood she has been taught to survey herseif continualiy.

What can be taken from the paintings of Palma Vecchio? It is clear that knowledge

\footnotetext{
Goffen. Tinan's Womon. Yale University Press, New Haven. 1997.9. Partidge. L.. Titina's Women

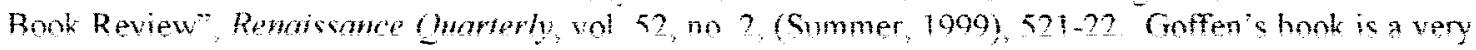
moden interpretuon which challenges the unveral assumption by critics that his portaits of women

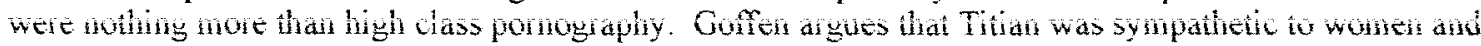
represented them as empowered, seif-possessed, fuily in command of their boties and emotions, and onten even assertive toward the males wh whom they interacted, including viewers.

Berger. J. Wavs of Seemg. Penguin Group, London, 1972, 46.
} 
of the social elements of sixteenth-century Venice is an absolute necescity when sepking

an understanding of his twenty female portraits.

It is acceptable to end his paper with a poem by Petratch. Within the verses, Petrarch expresses his desperate desire to declare his love for Laura in the most aftable manner he can. His dilemma lies in the fact that he feels there are no accurate methods to clearly exnress his love for the fair lady

"A chamed sometimes, my lady, that I still cannot express your beauty in my rinyme, I wander to that sweet and distant time when you alone gained power of my will.

But eventhere ifind no guiling skit, no strength to scale a height I cannot climb. for such a task demands a force sublime, at whose attompt I fall back, must and still.

How often do I move my lips to speak. and find hy volce lies buted in my breast but then, what sound could ever rise on high?

How often do i seek to find the words my tongue cannot express, but pen and hand are vanquished with each try.

in its purest form, conceivably, Renaissance men feit this way about the ideal fonimine beaty they were so desperate to encounter and possess. The dewelopment of an image that would appease their wildest dreams could be conjured, and they would at last nossess the beauty they so adamantly desired. Thus followed the phenomenon which took piace in the worid of femaie portraiture

Petrarch, F. For Love of Latra: Poetry of Petrarch. Translation by Marion Shore, The University of Arkansas Press Favetteville 1987. 23 


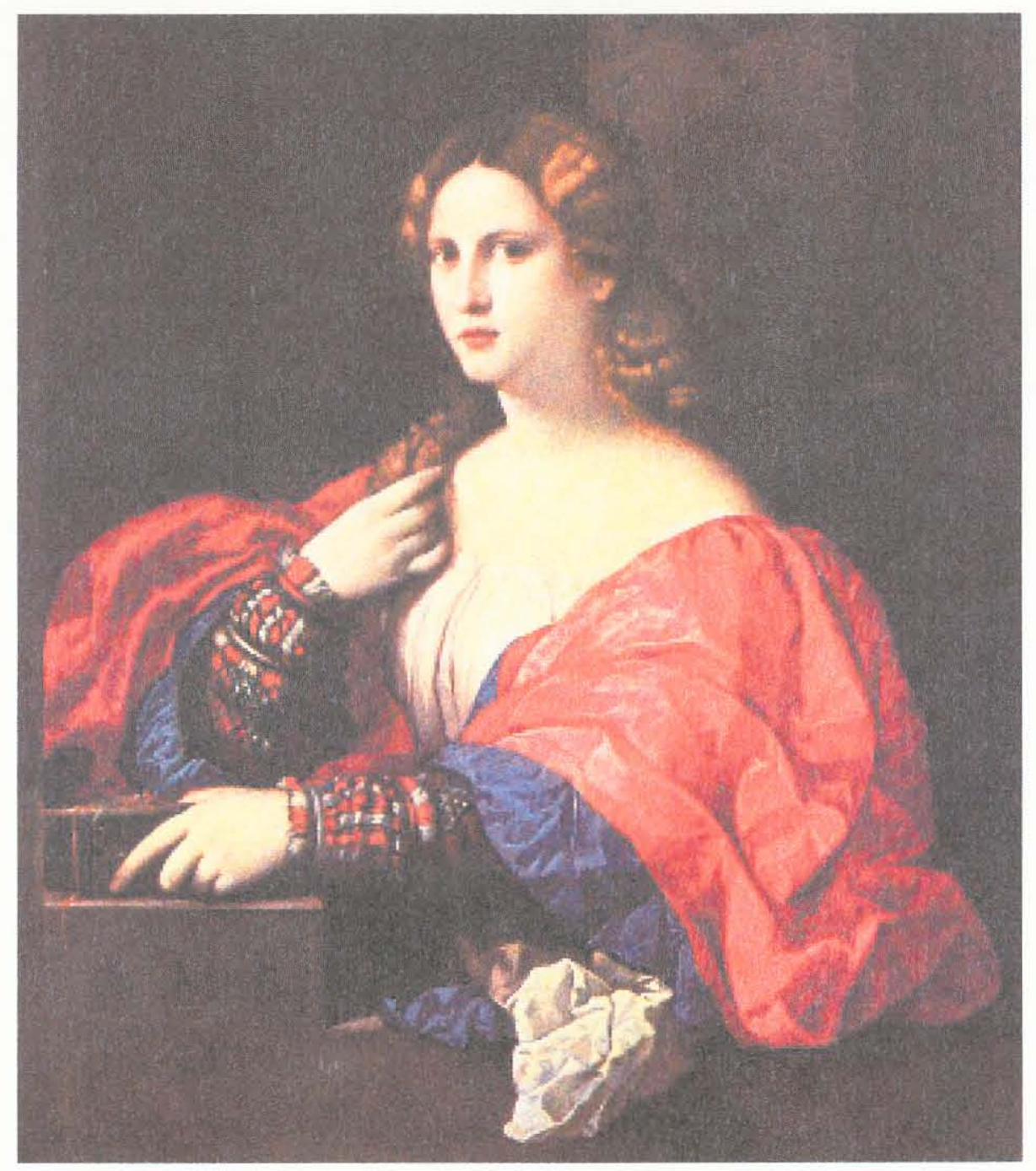

Figure 1. Palma Vecchio. Portrait of a Woman Called 'la Bella', 1518-20. Oil on canvas, $90 \times 80 \mathrm{~cm}$. Lugano - Castagnola Collection Thyssen Bomenisza.

Photograph from Philip Ryland's book Palma Vecchio, p. 99. 


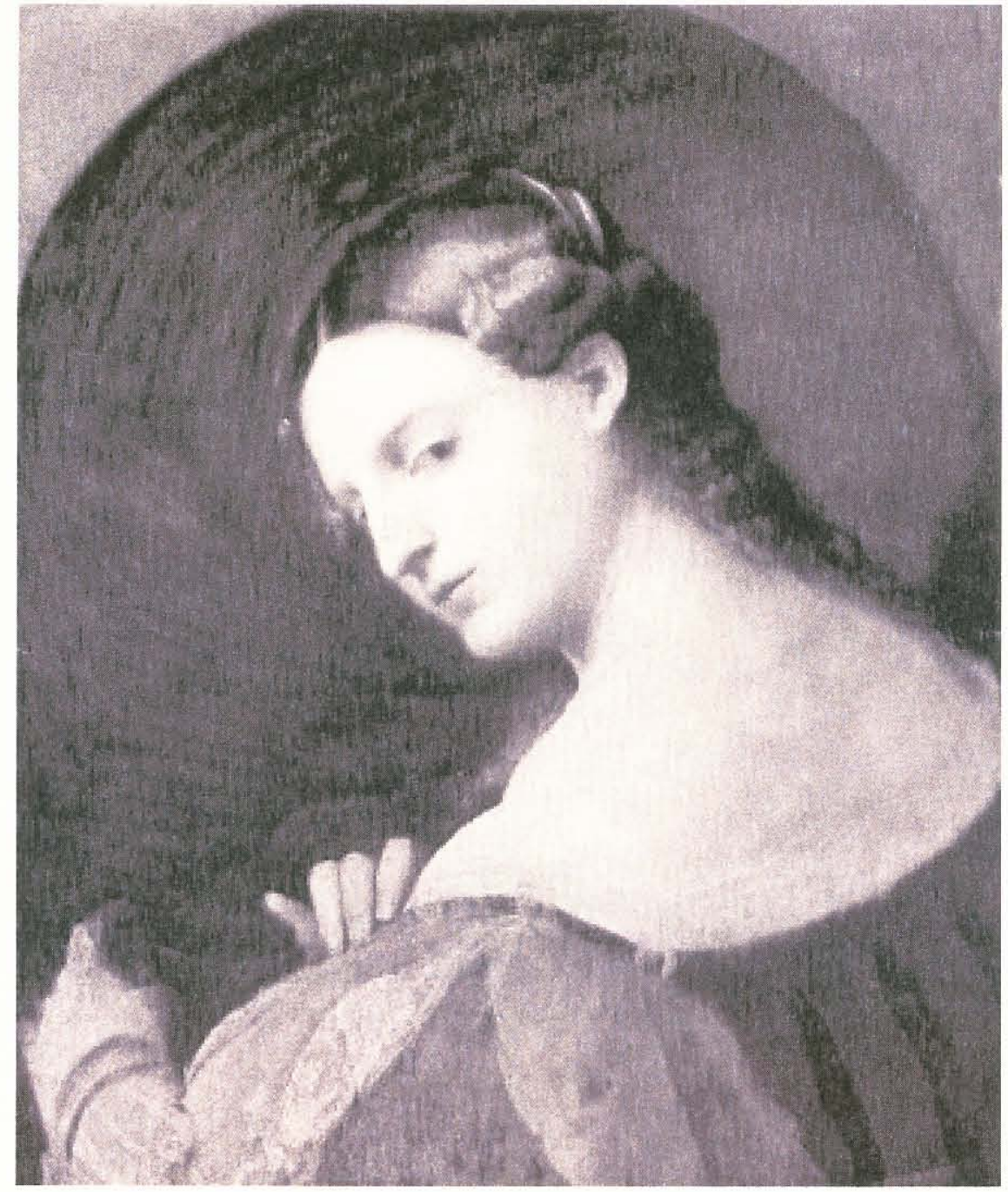

Figure 2. Palma Vecchio. Portrait of a Woman in Profile, c. 1520-25. Oil on panel, 49 x $42.4 \mathrm{~cm}$. Kunsthistorisches Museum, Vienna.

Image courtesy of Philip Ryland's book Palma Vecchio, p. 99. 


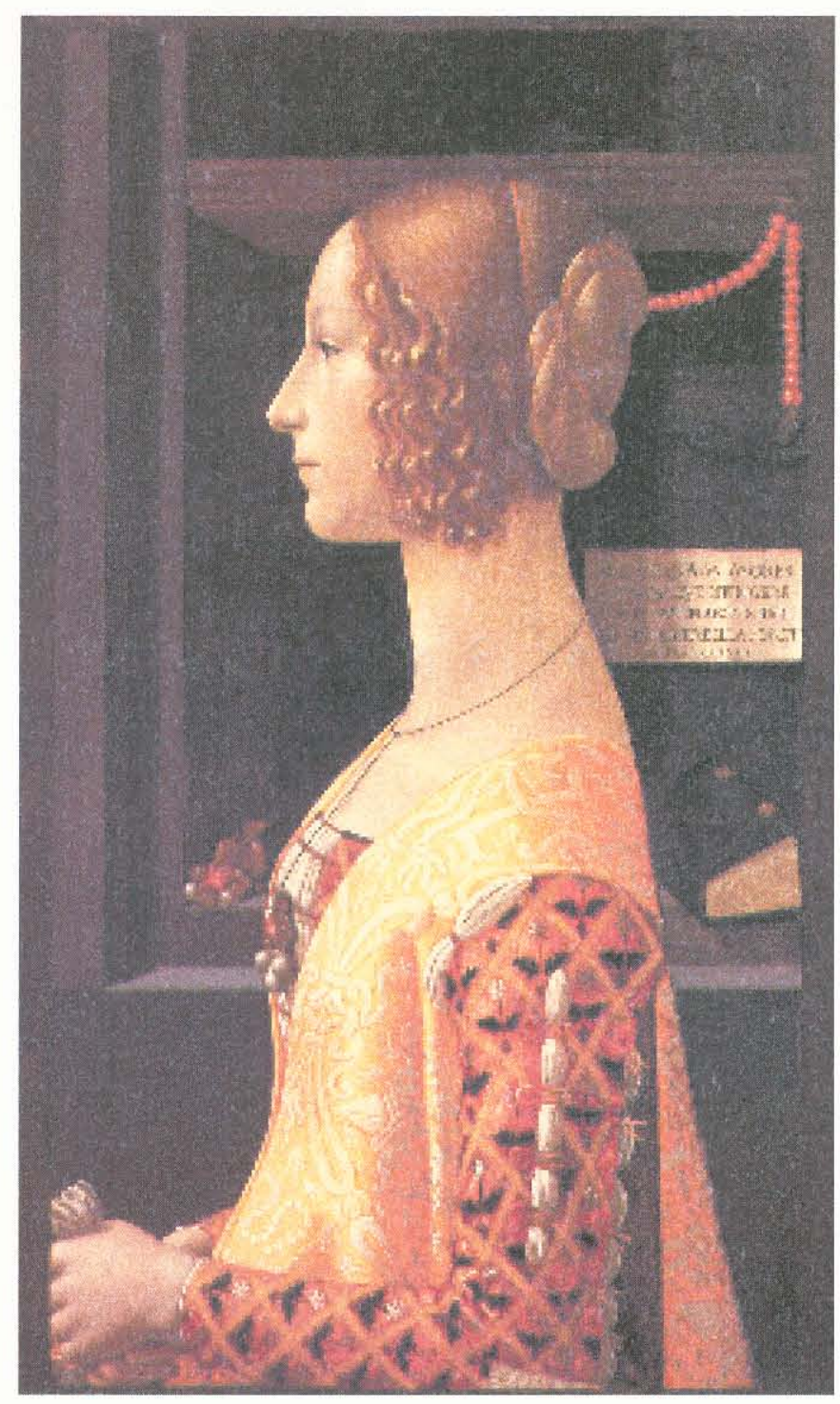

Figure 3. Domenico Ghirlandaio. Portrait of Giovanna degli Albizzi Tornabuoni, c. 148890. Tempera on panel, 77 x $49 \mathrm{~cm}$. Museo Thyssen-Bornemisza, Madrid.

Photograph from Virtue and Beauty. Leonardo's Ginevra de Benci and Renaissance Portraits of Women. National Gallery of Art, Washington, D.C., p. 191. 


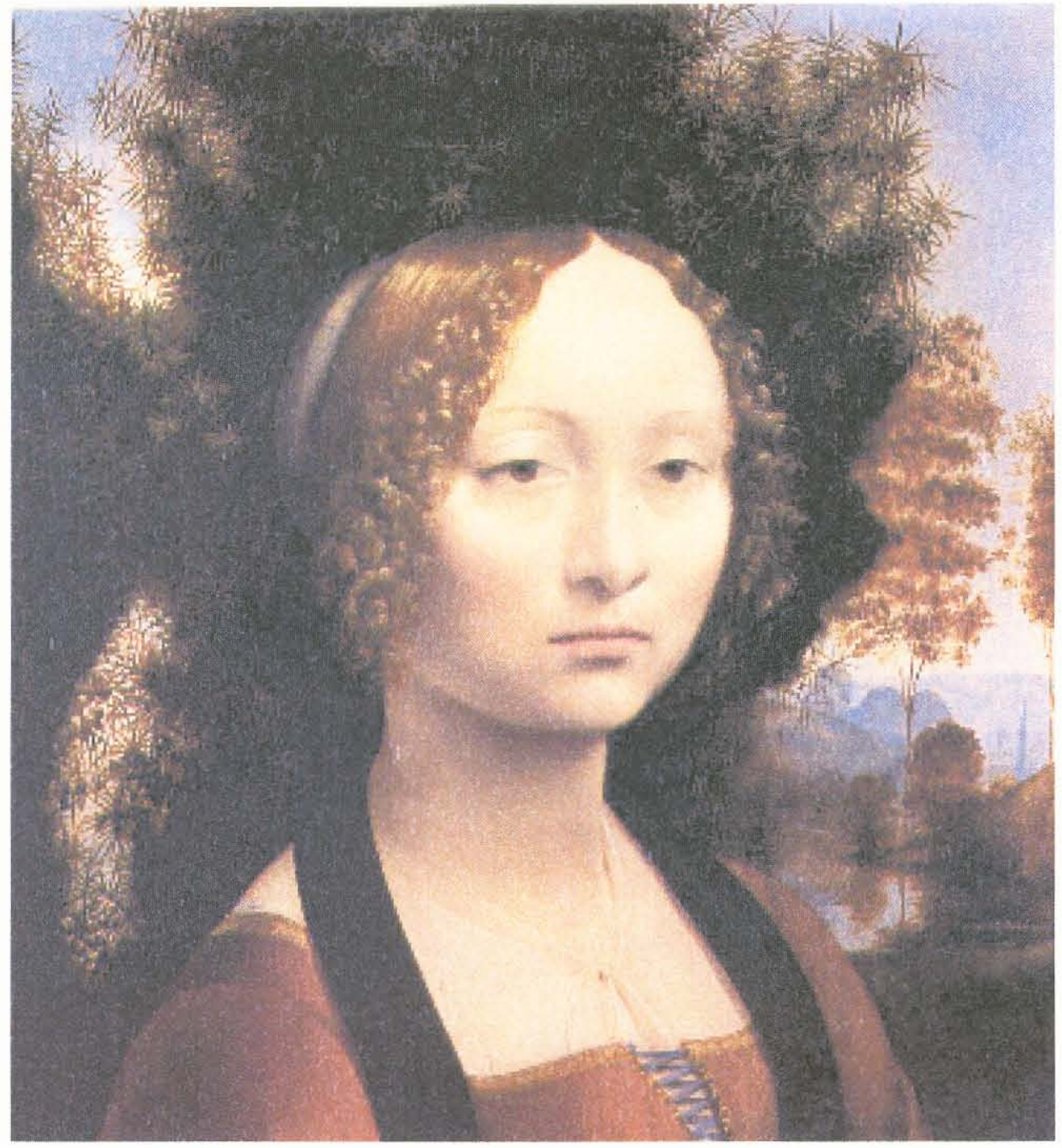

Figure 4. Leonardo da Vinci. Portrait of Ginevra de Benci, 1474-78. Oil on panel, $38.1 \times$ $37 \mathrm{~cm}$. National Gallery of Art, Washington, D.C.

Photograph from Virtue and Beauty. Leonardo's Ginevra de Benci and Renaissance Portraits of Women. National Gallery of Art, Washington, D.C., p. 143. 


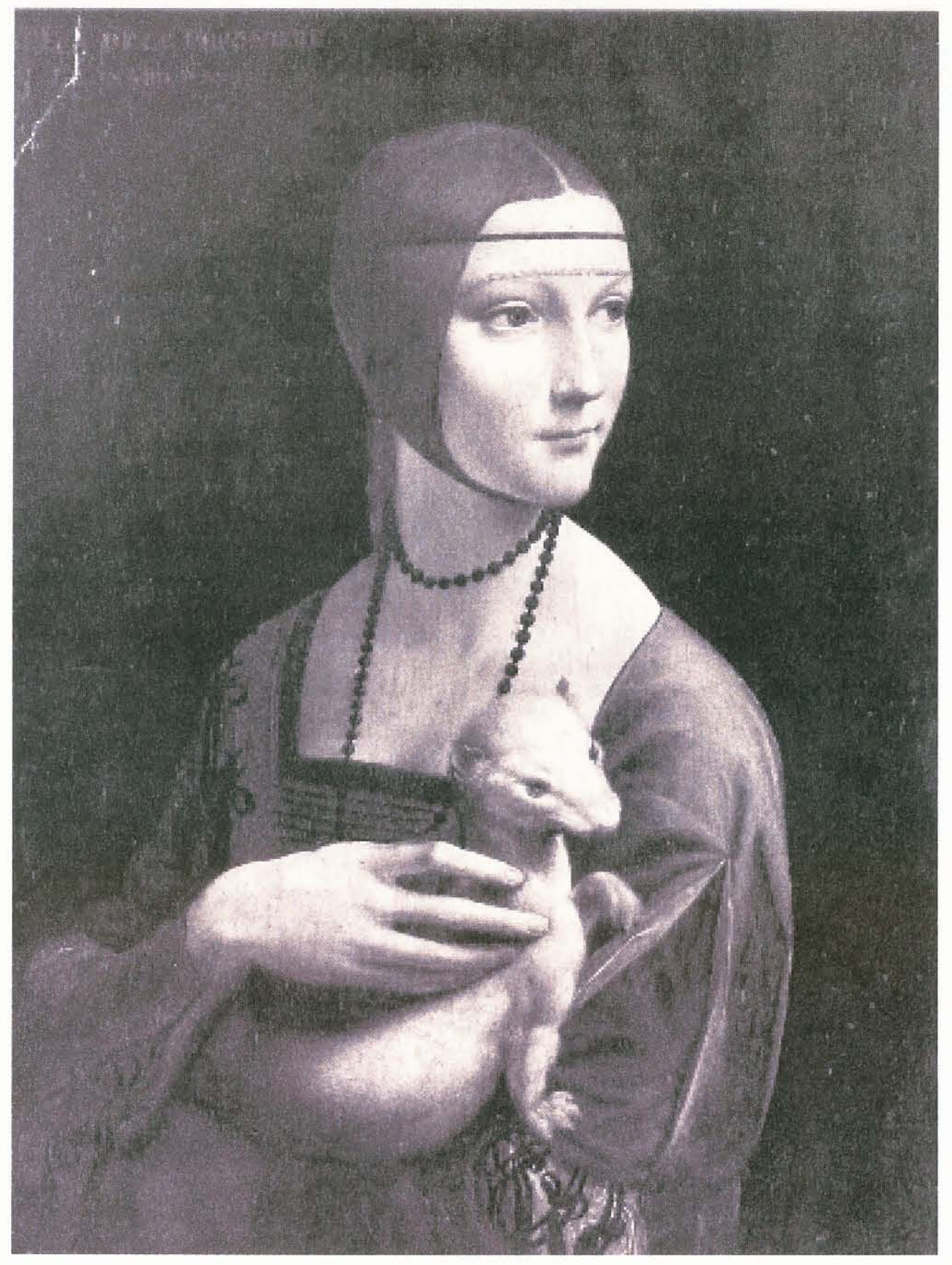

Figure 5. Leonardo da Vinci. Portrait of Cecilia Gallerani (Lady with Ermine), 1489-90. Oil on panel. Krakow, Princes Czartoryski Foundation.

Photograph from Lynn Lawner's book Lives of the Courtesans, p. 117. 


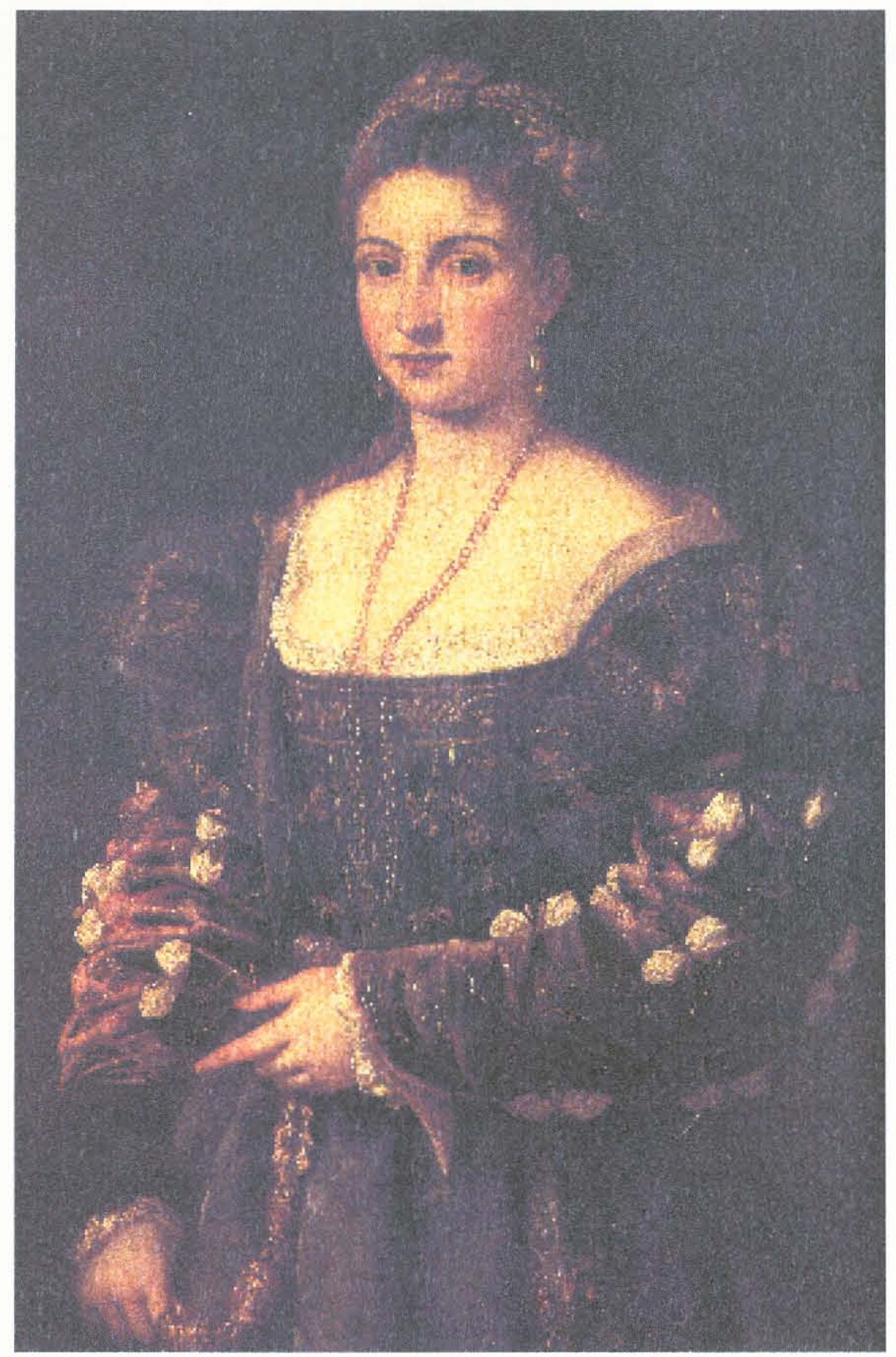

Figure 6. Titian. Portrait of a Woman Called La Bella, 1536. Oil on canvas. Galleria Pitti, Florence.

Photograph from Rona Goffen's book Titan's Women, p. 78. 


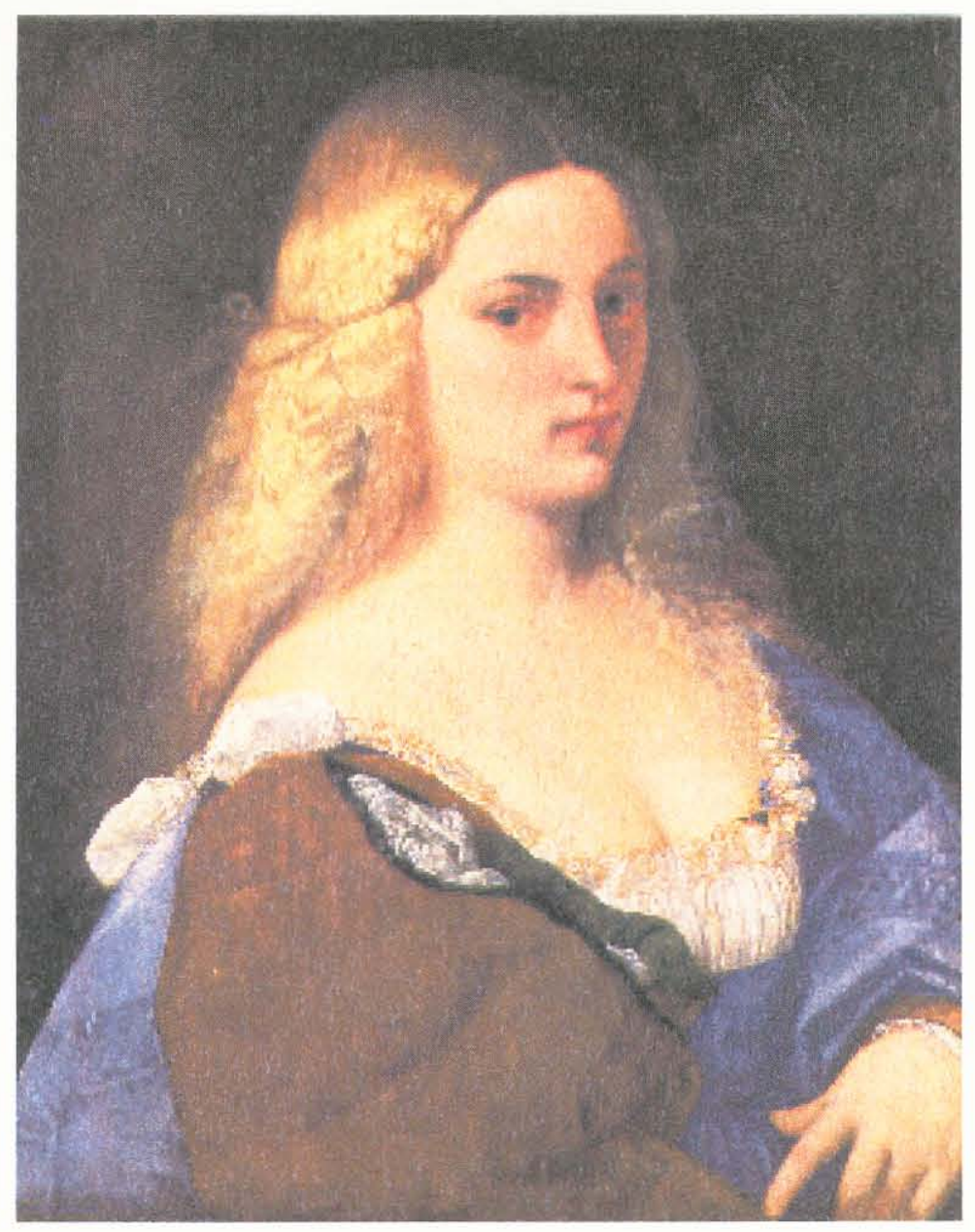

Figure 7. Palma Vecchio. Portrait of a Woman Called Violante, 1516-18. Oil on canvas, $64.5 \times 50.8 \mathrm{~cm}$. Kunsthistorisches Museum, Vienna.

Photograph from Philip Ryland's book Palma Vecchio, p. 99. 


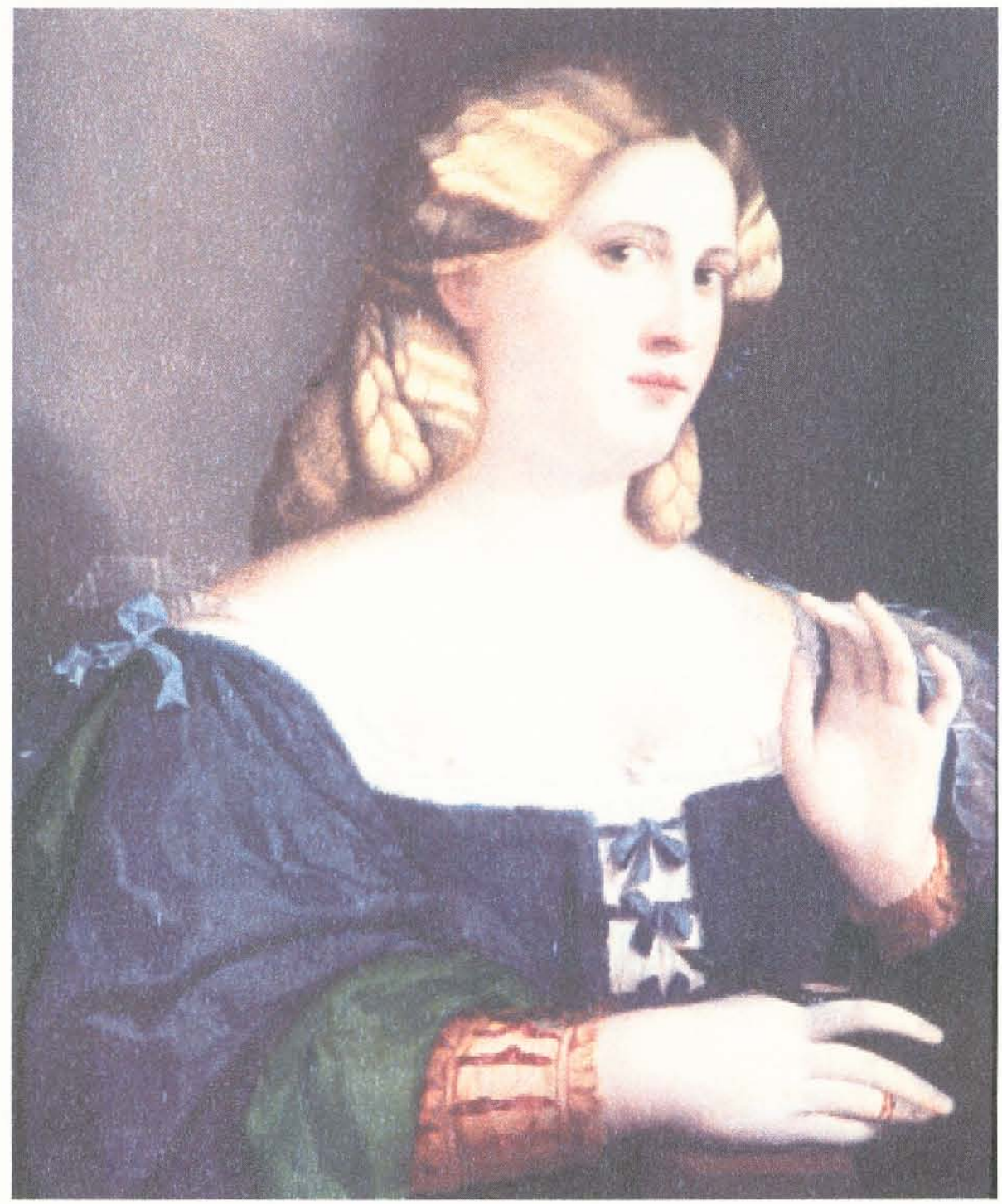

Figure 8. Palma Vecchio. Portrait of a Woman in Blue, 1512-14. Oil on canvas, $63.5 \times 51$ $\mathrm{cm}$. Kunsthistorisches Museum, Vienna.

Photograph from Philip Ryland's book Palma Vecchio, p. 98. 


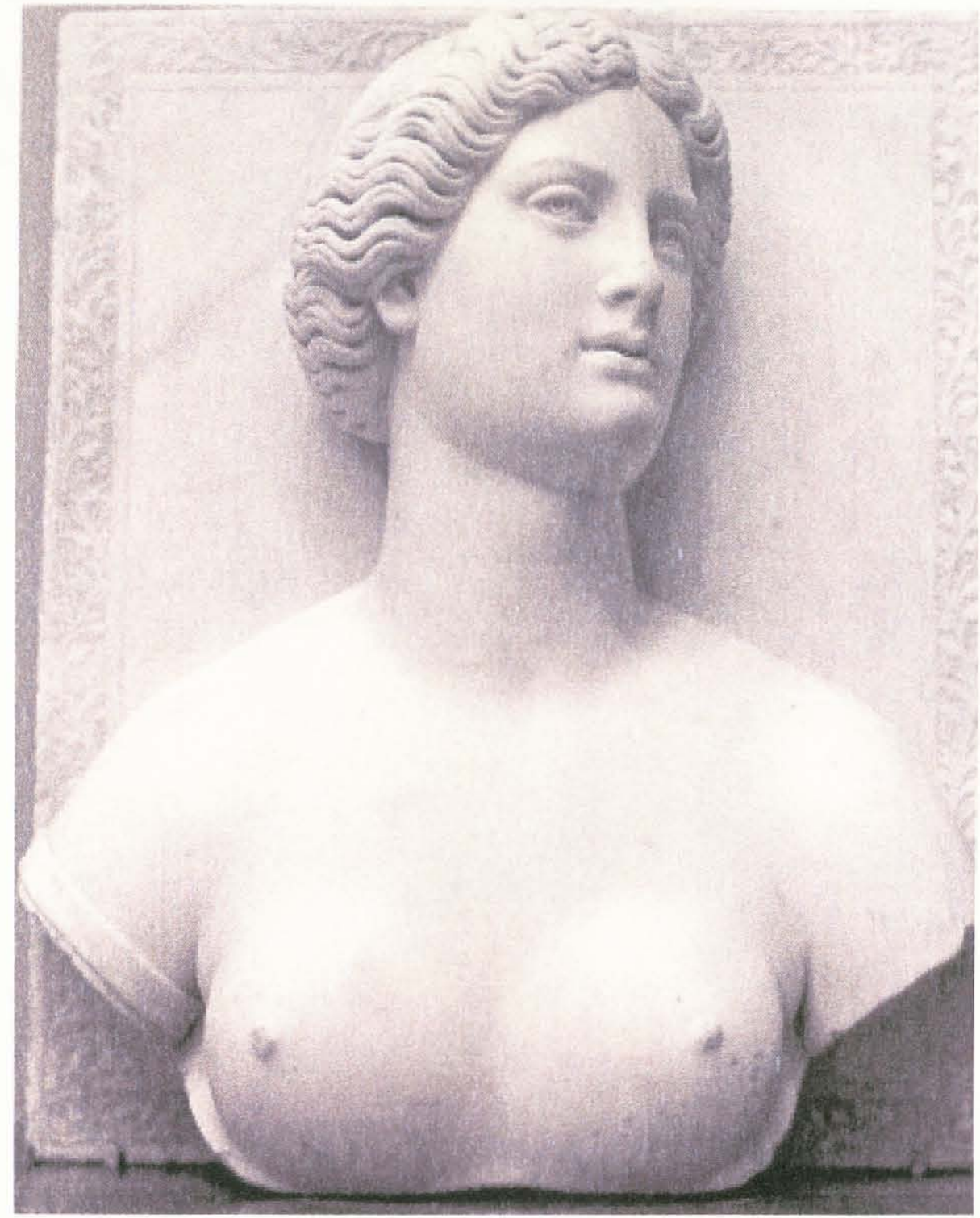

Figure 9. Tullio Lombardo. Portrait Bust of a Woman, 1520. Marble. Private Collection.

Photograph from Alison Luchs' book Tullio Lombardo's Ideal portrait Sculpture in Renaissance Venice, 1490-1530, p. 279. 


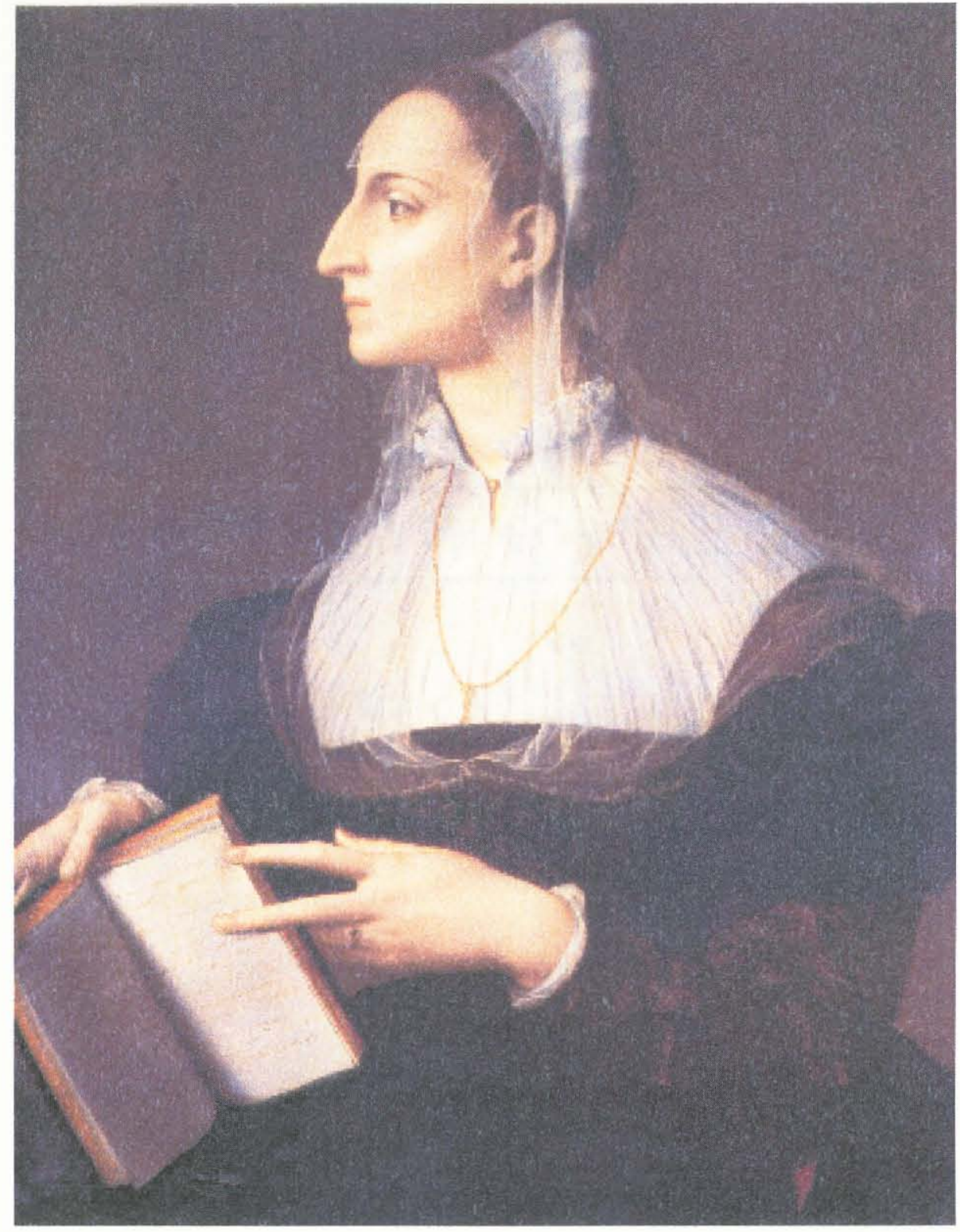

Figure 10. Bronzino. Portrait of Laura Battiferri, 1558. Oil on panel, $83 \times 60 \mathrm{~cm}$. Palazzo Vecchio, Florence.

Photograph from Marice Brock's Bronzino, p. 95. 


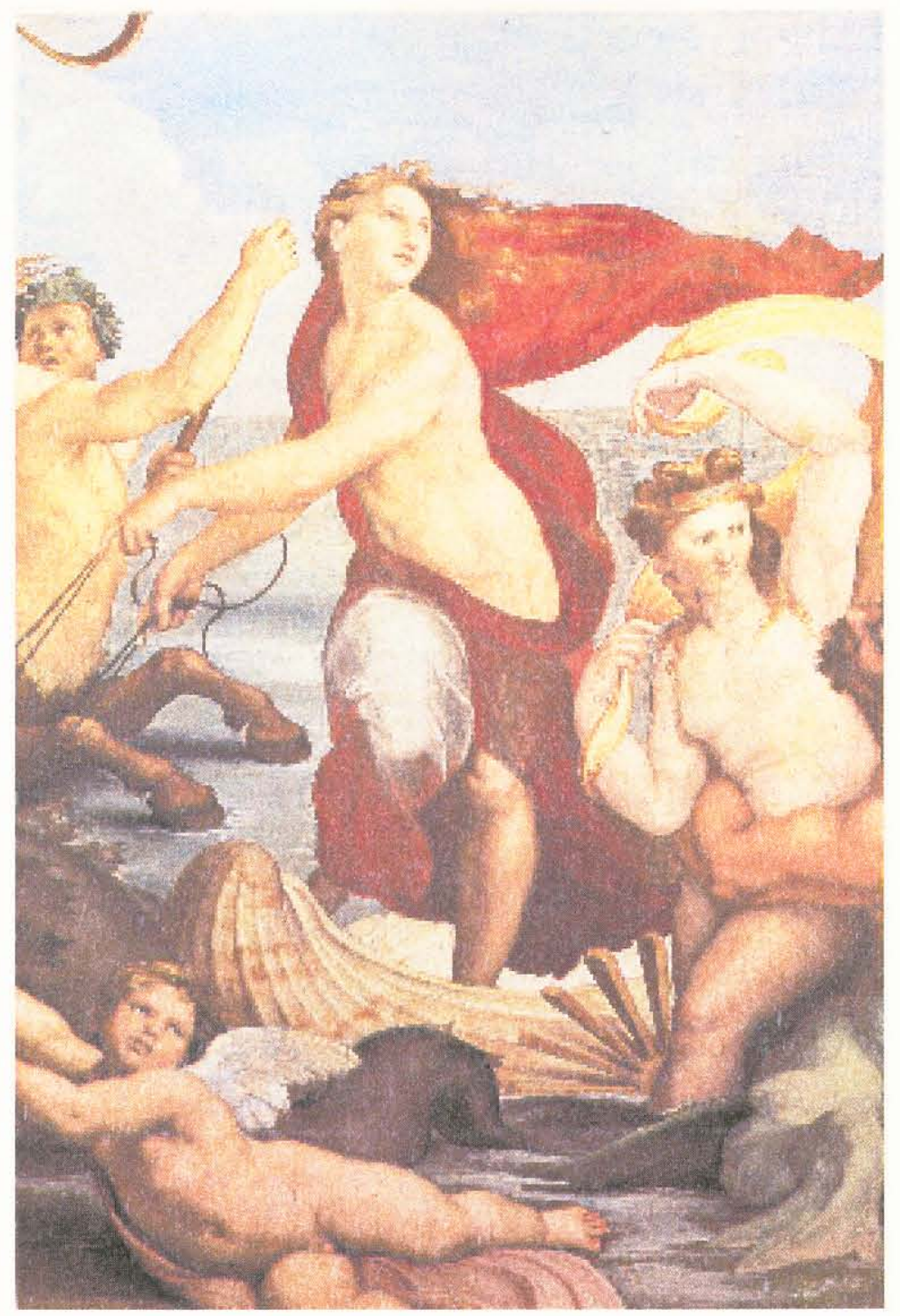

Figure 11. Raphael. Detail from Galatea, c. 1518. Fresco, Villa Farnesina, Rome.

Photograph from Lynn Lawner's Lives of the Courtesans, p. 38. 


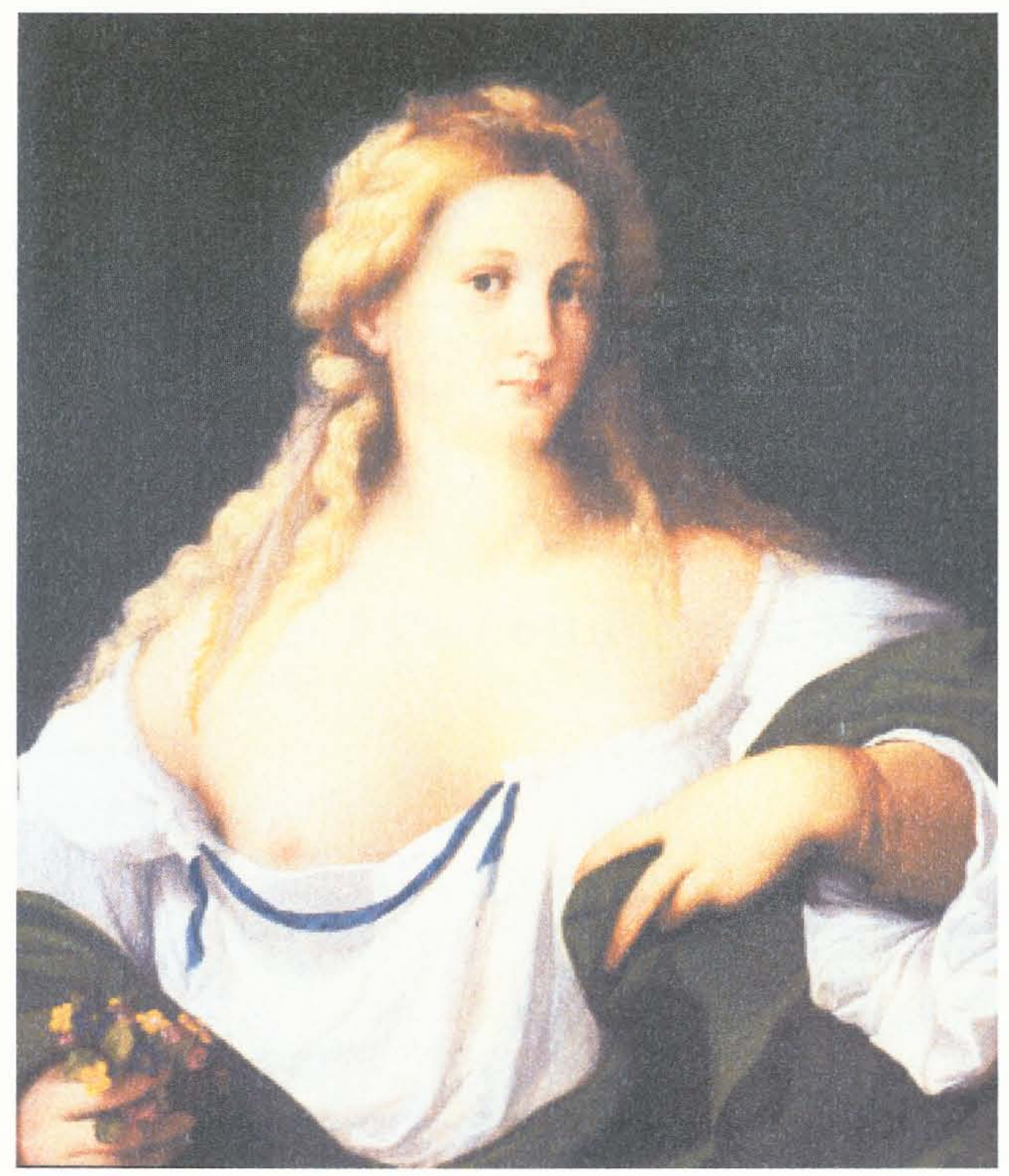

Figure 12 Palma Vecchio. Portrait of a Woman Called Flora, 1522-24. Oil on panel, 77 x $64 \mathrm{~cm}$. National Gallery, London.

Photograph from Philip Ryland's book Palma Vecchio,p. 208. 


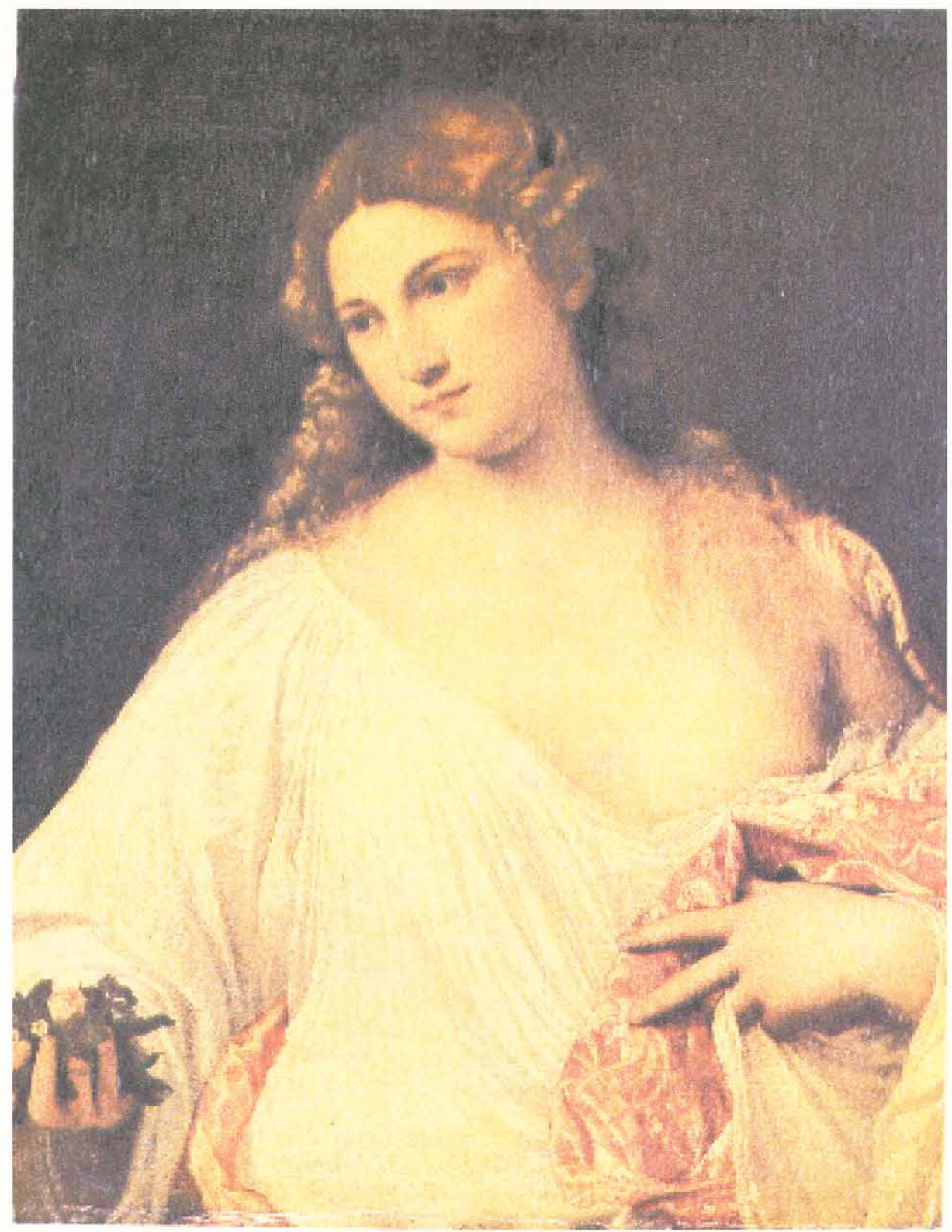

Figure 13. Titian. Portrait of a Woman Called Flora, c. 1516-18. Oil on canvas. Gallerie degli Uffizi, Florence.

Photograph from Rona Goffen's book entitled Titian's Women, p. 73. 


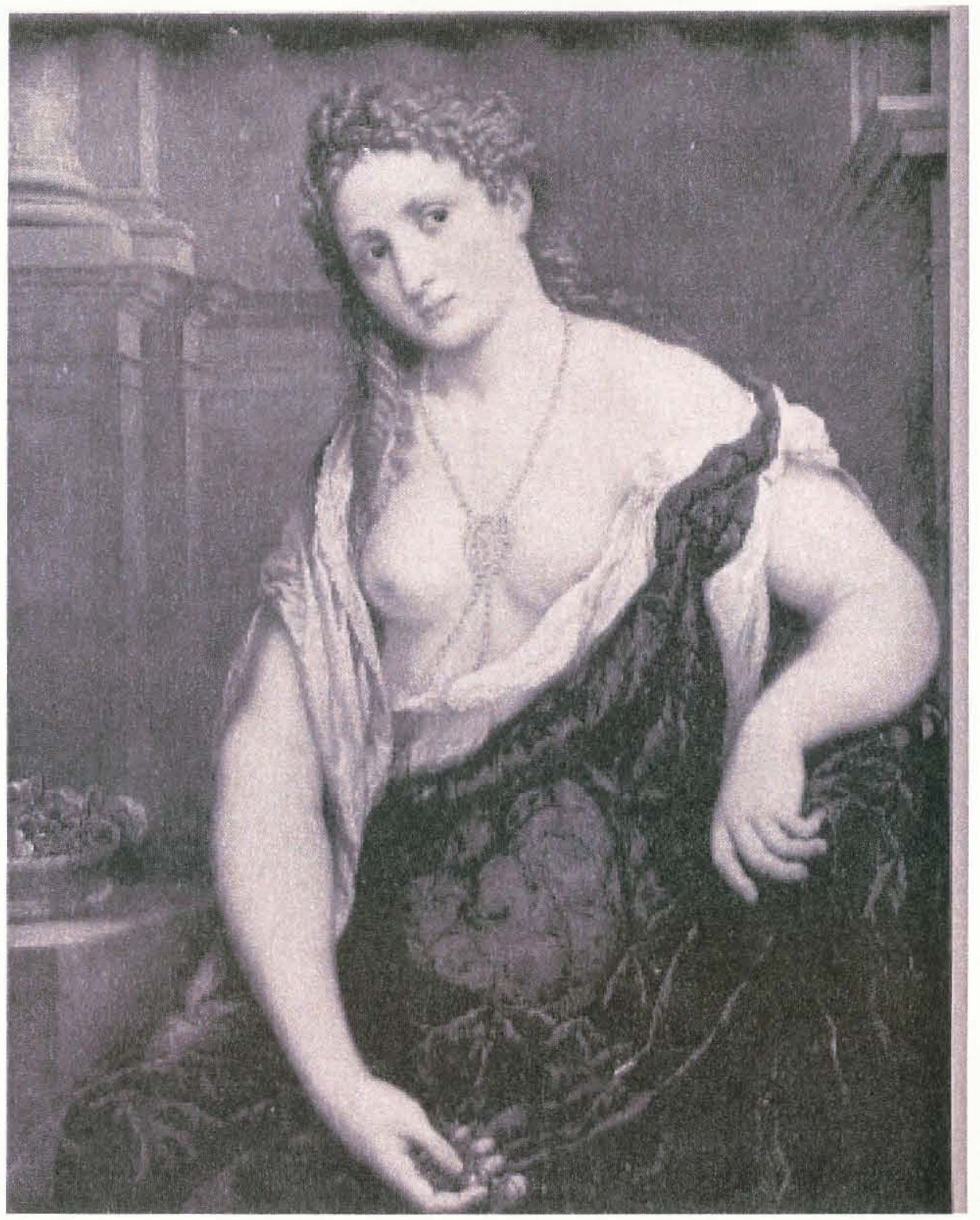

Figure 14. Paris Bordon. Portrait of a Woman Called Flora, 16th century. Oil on canvas, $103 \times 85 \mathrm{~cm}$. Musee du Louvre, Paris

Photograph from Paris Bordon, Electa, Milan, 1984, p. 80. 


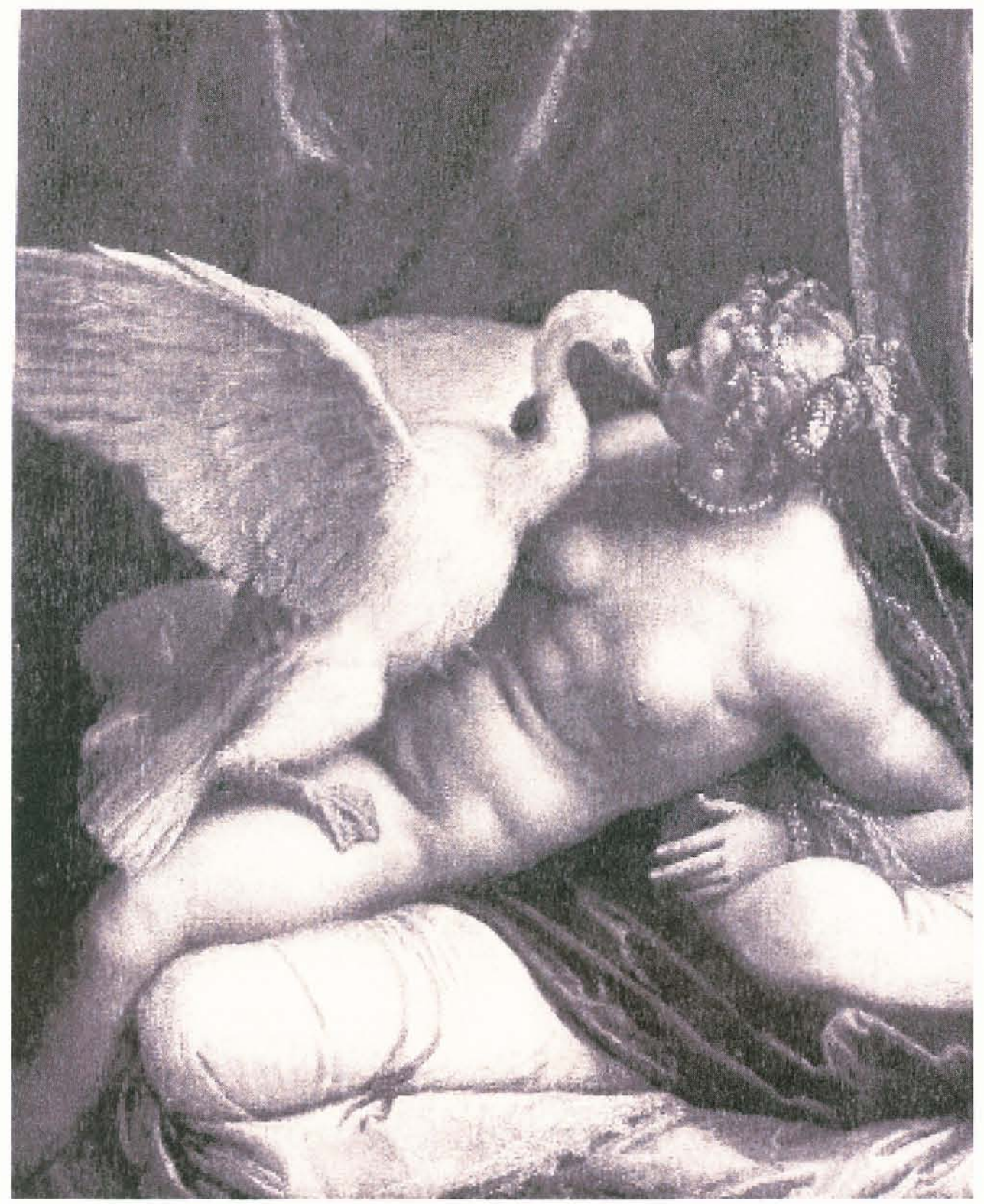

Figure 15. Veronese. Leda and the Swan, 16th century. Oil on canvas?

Photograph from Lynn Lawner's book Lives of the Courtesans, p. 107. 


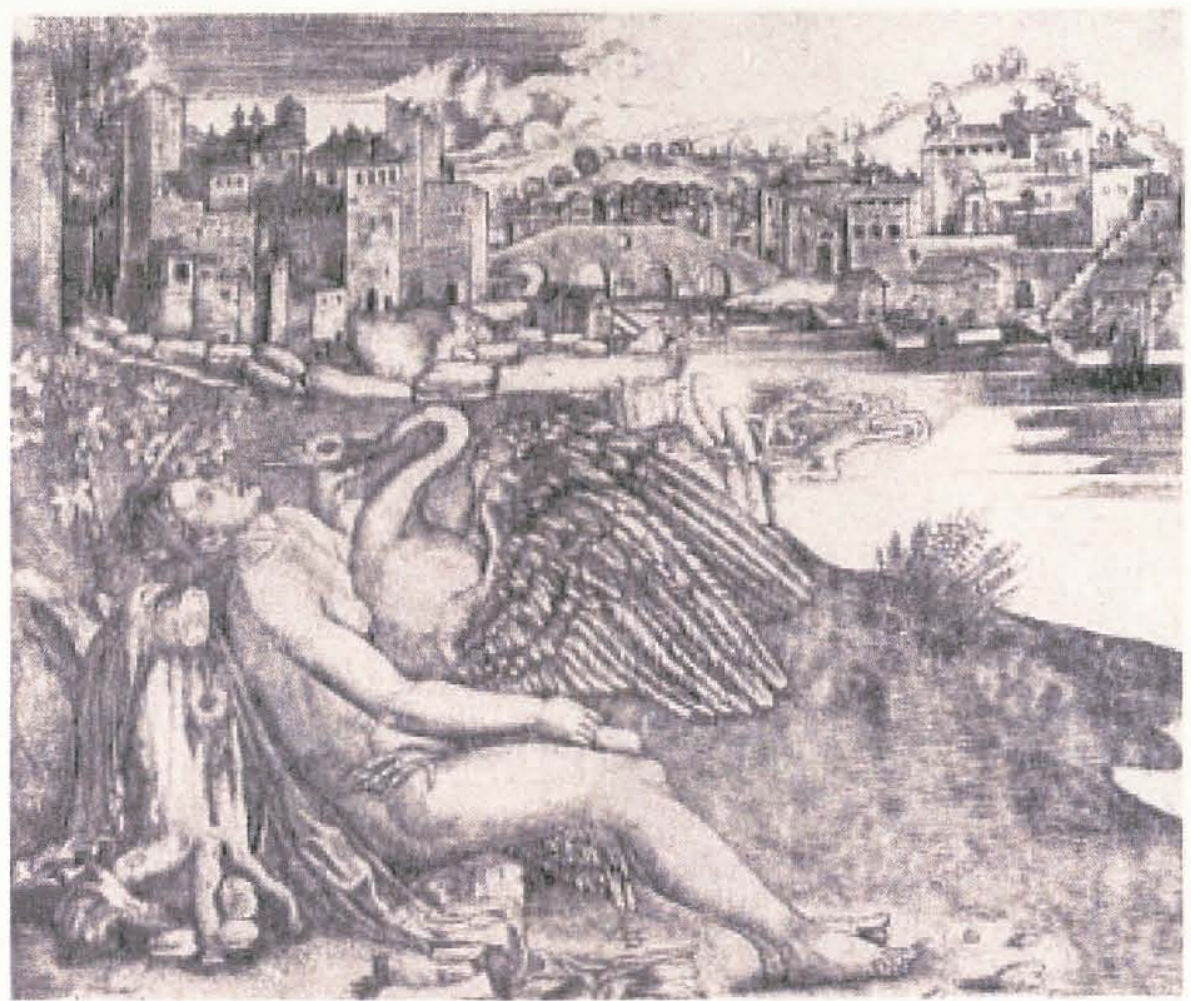

Figure 16. Marcantonio Raimondi. Leda and the Swan, 1520. Engraving,

Photograph from Lynn Lawner's book Lives of the Courtesans, p. 106. 


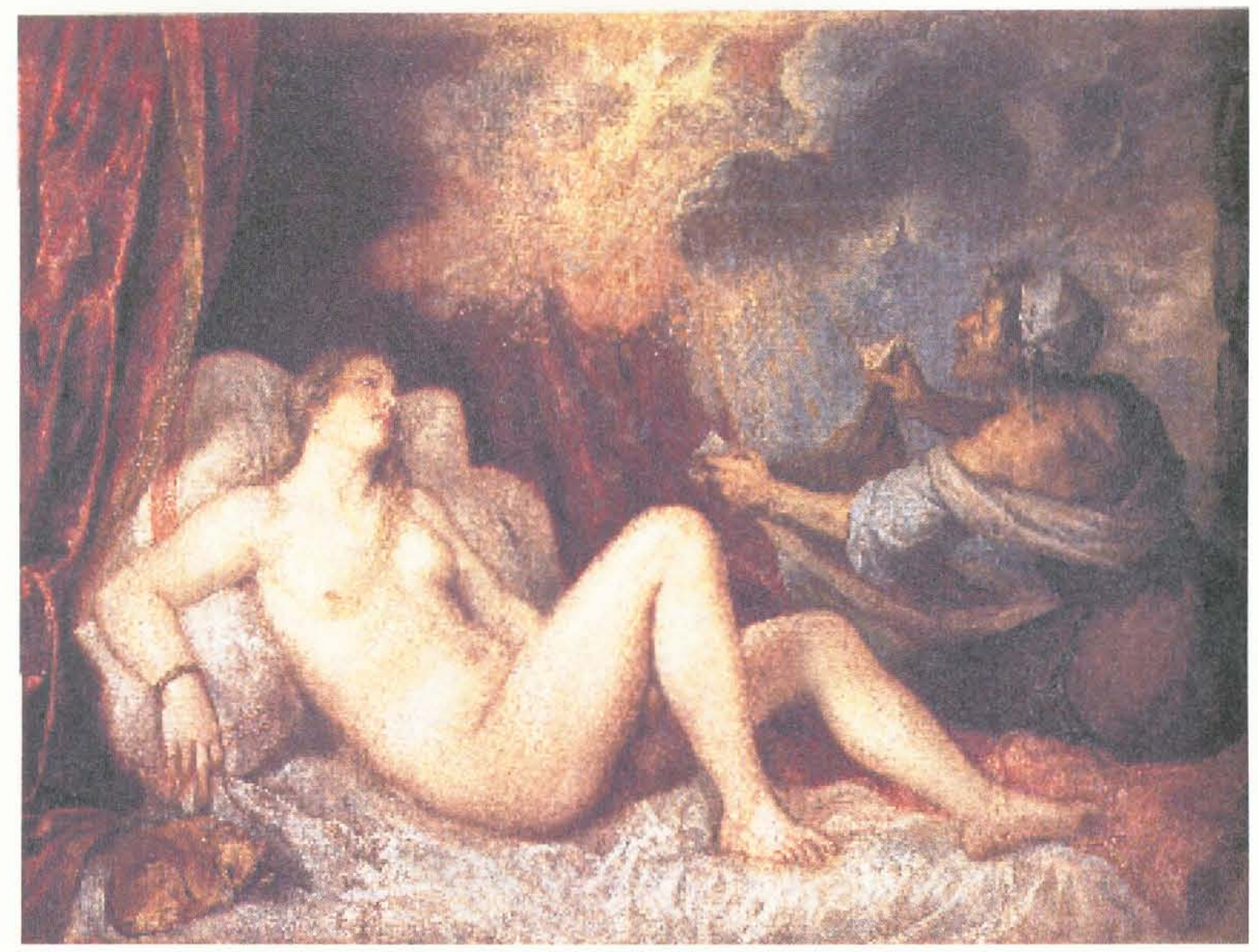

Figure 17. Titian. Danae and the Golden Shower, c. 1545. Oil on canvas, Prado Museum, Madrid

Photograph from Rona Goffen's book Titian's Women, p. 220. 


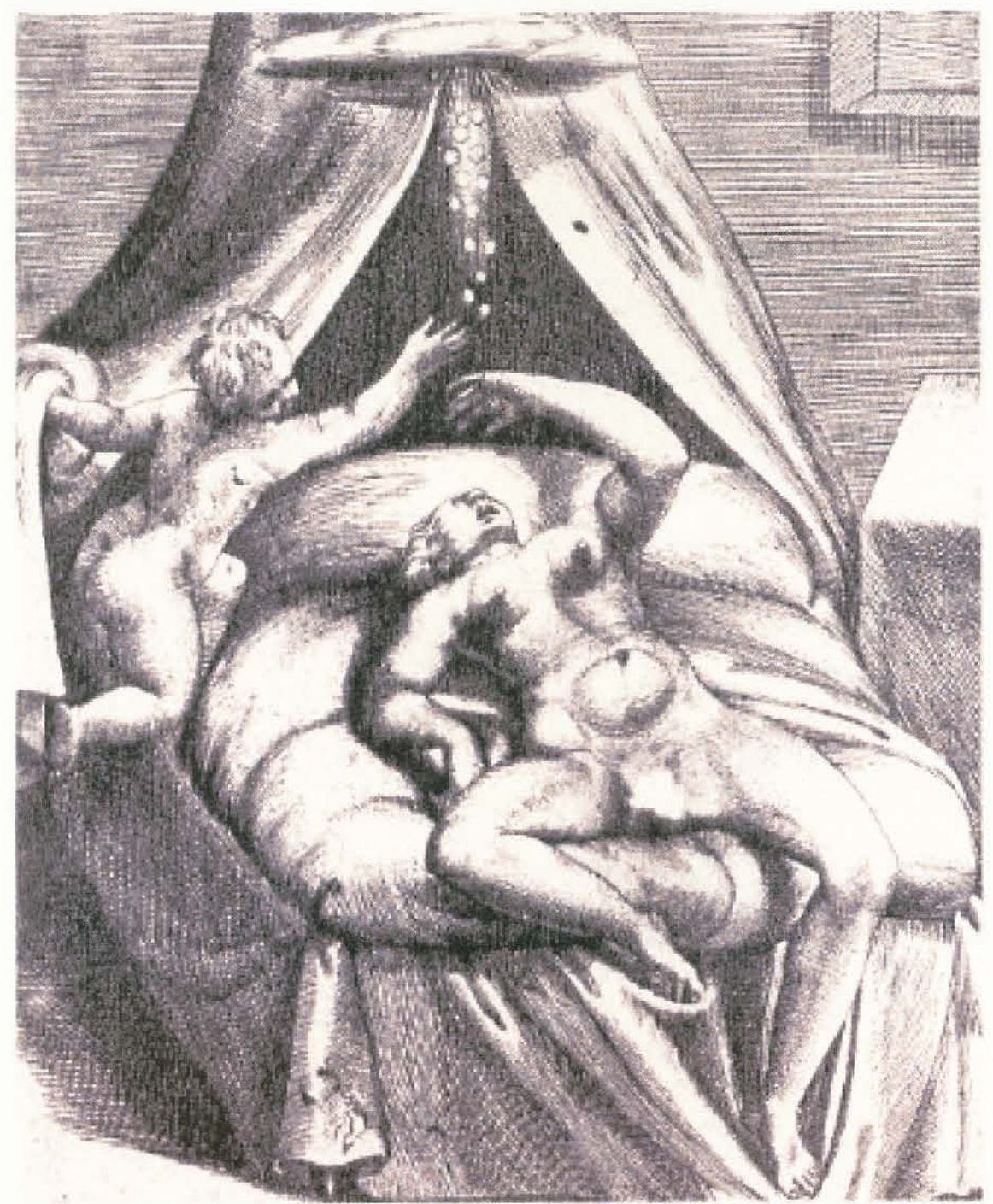

Figure 18. Giulio di Antonio Bonasone. Danae, 1545. Engraving.

Photograph from Lynn Lawner's book Lives of the Courtesans, p. 110. 


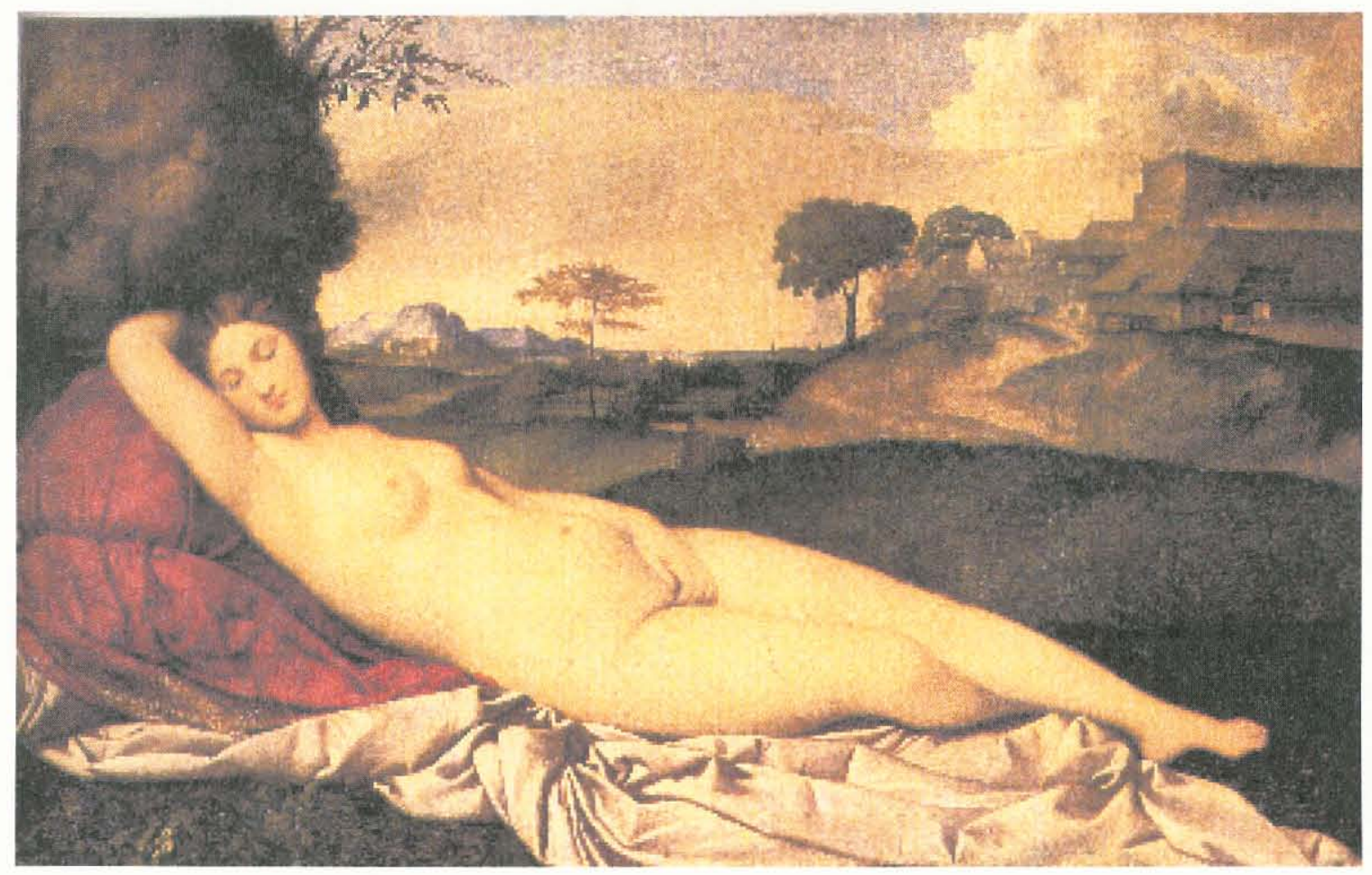

Figure 19. Giorgione. Sleeping Venus (Dresden Venus), 1510. Oil on panel, Staatliche Gemaldegalerie, Dresden.

Photograph from Jaynie Anderson’s book Giorgione, p. 219. 


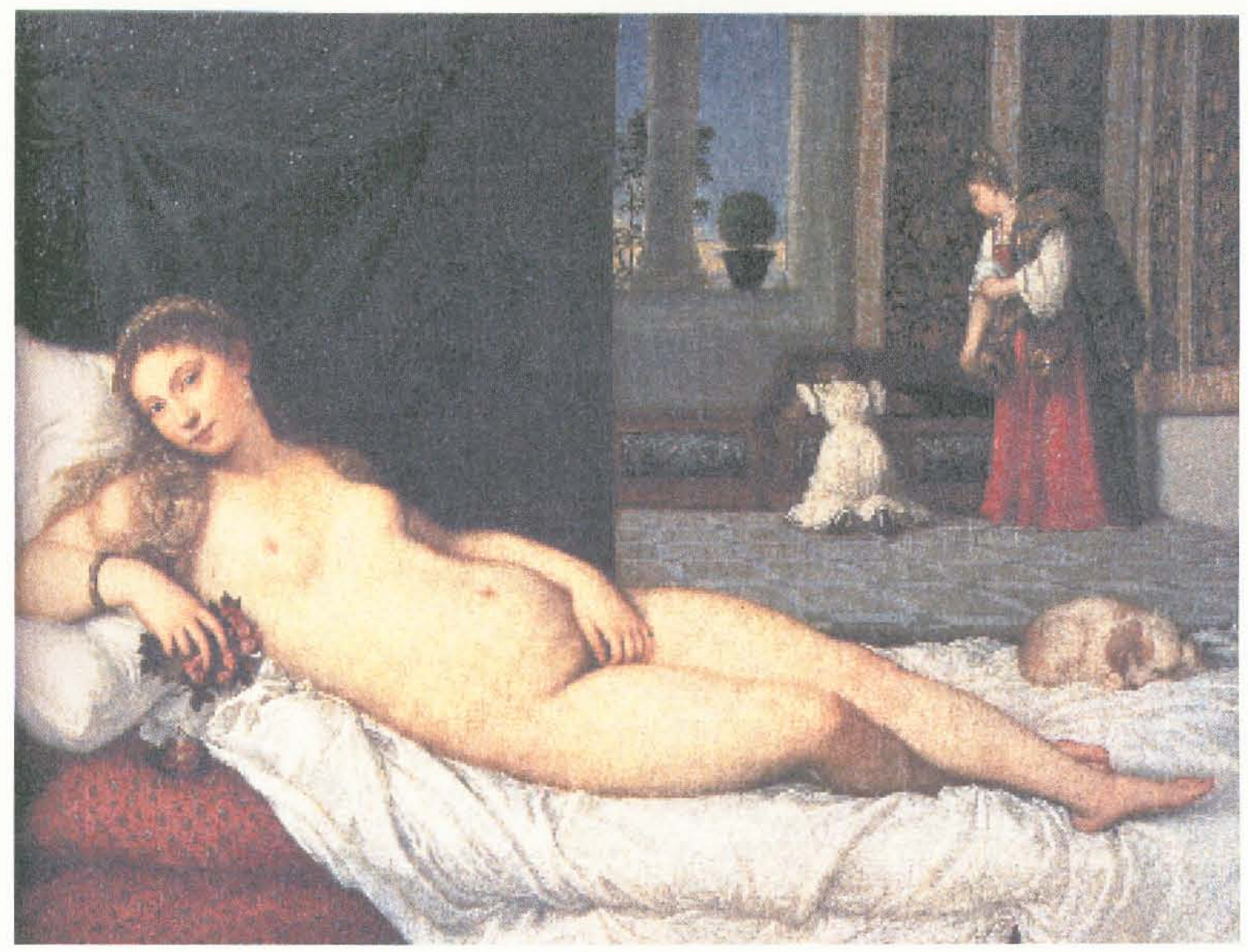

Figure 20. Titian. Venus of Urbino, 1538. Oil on panel, Gallery degli Uffizi, Florence.

Photograph from Rona Goffen's Titian's Women, p. 147. 


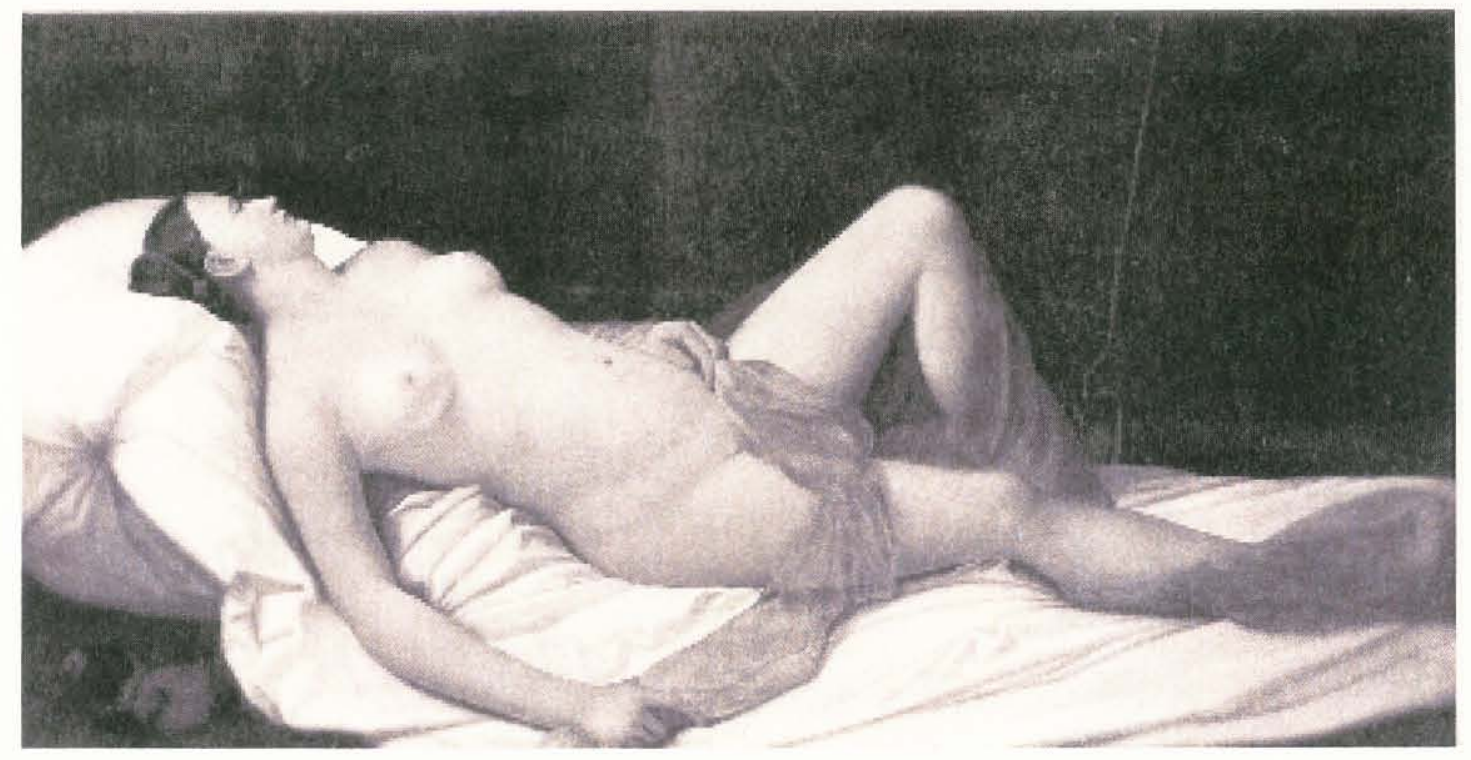

Figure 21. Bernardino Licinio. Reclining Venus, 16th century. Temporarily at Palazzo Vecchio.

Photography from Lynn Lawner's book Lives of the Courtesans, p. 135. 


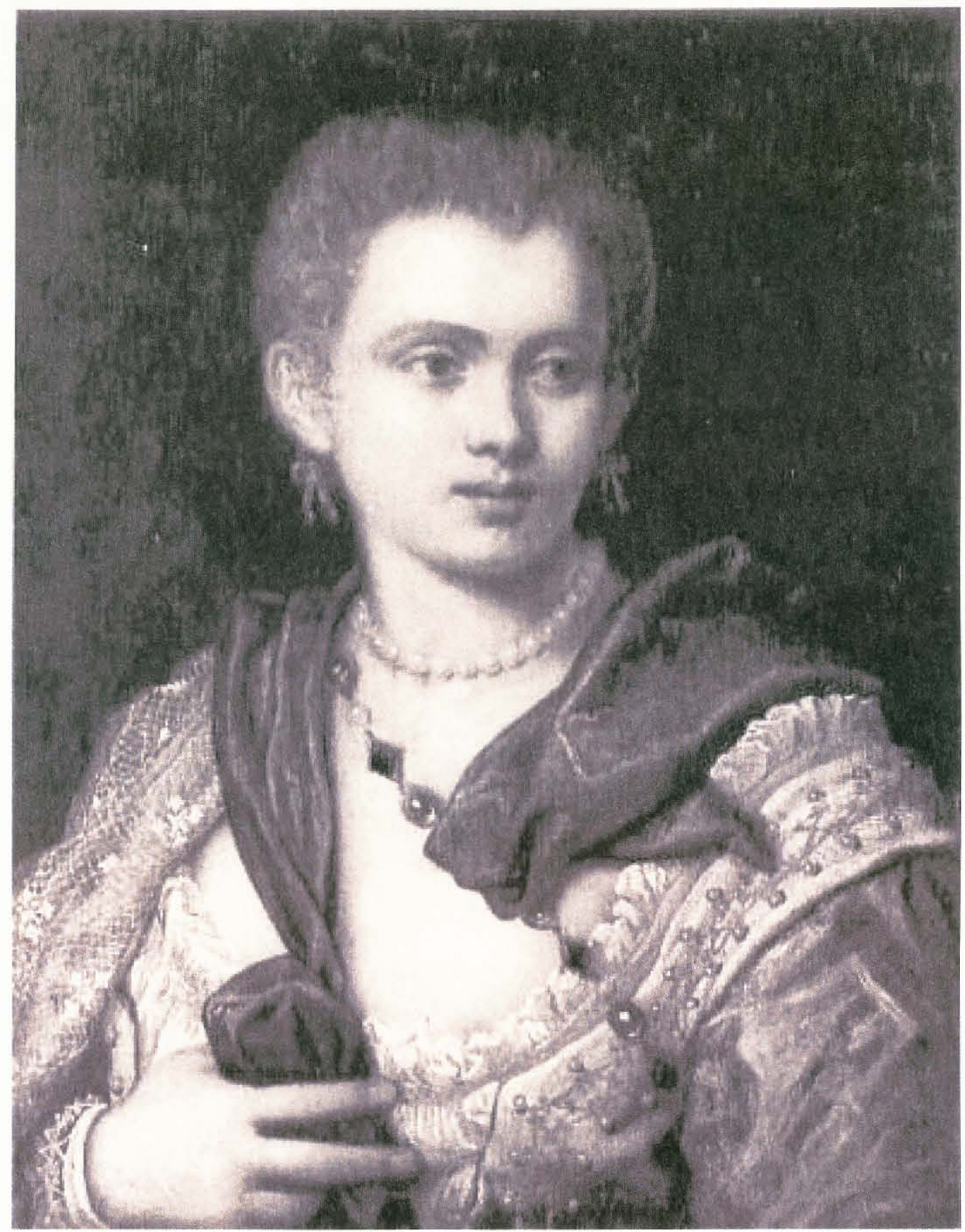

Figure 22. Tintoretto. Portrait of Veronica Franco, c. 1575. Oil on canvas, Worcester Art Museum, Worcester, Massachusetts.

Photograph from Margaret Rosenthal's book The Honest Courtesan. 


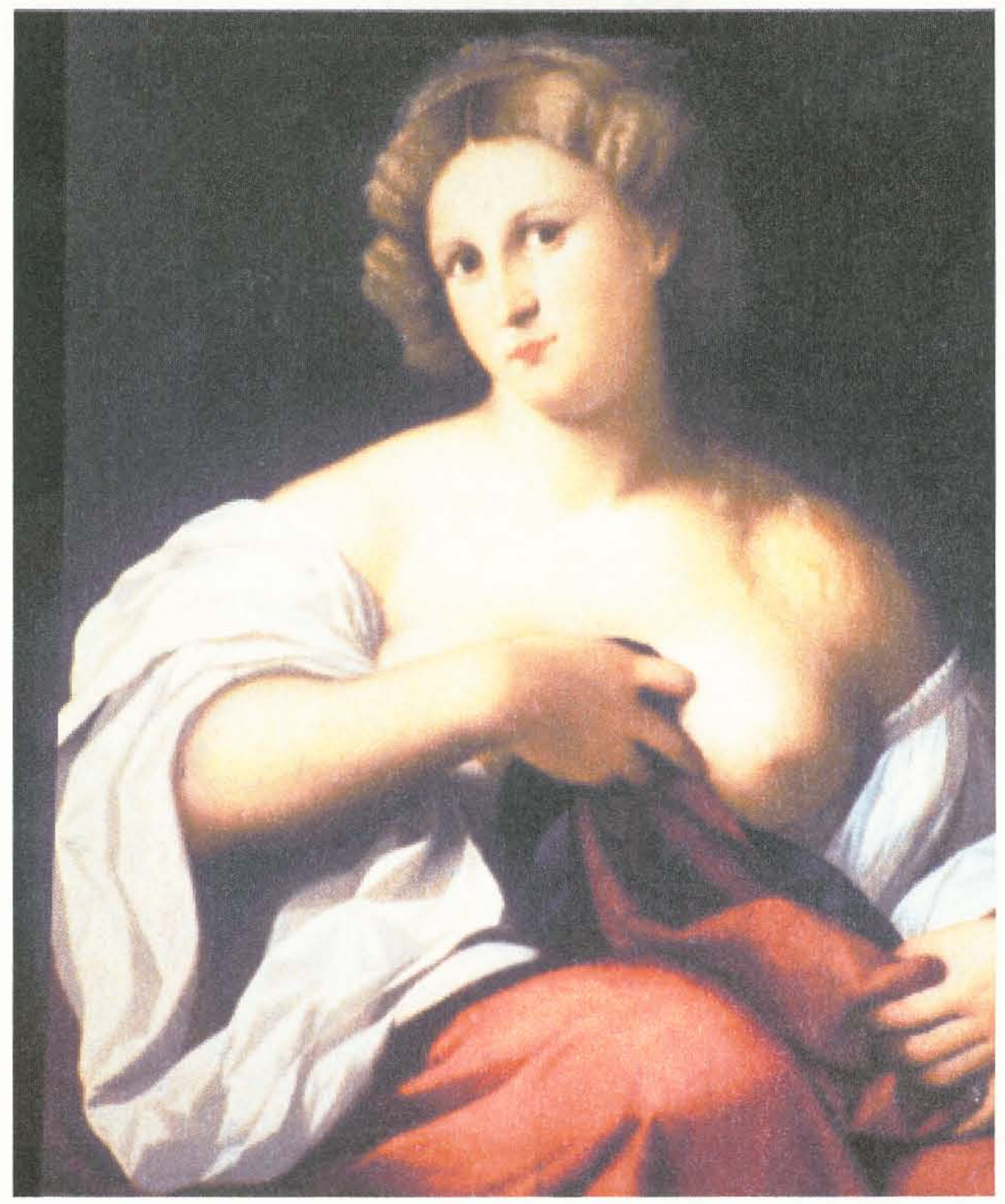

Figure 22. Palma Vecchio. Portrait of a Woman With a Bared Breast, 1524-26. Oil on panel, 79.1 x $62.2 \mathrm{~cm}$. Gemaldegalerie, Berlin (Dahlem).

Photograph from Philip Ryland's book Palma Vecchio, p. 222. 


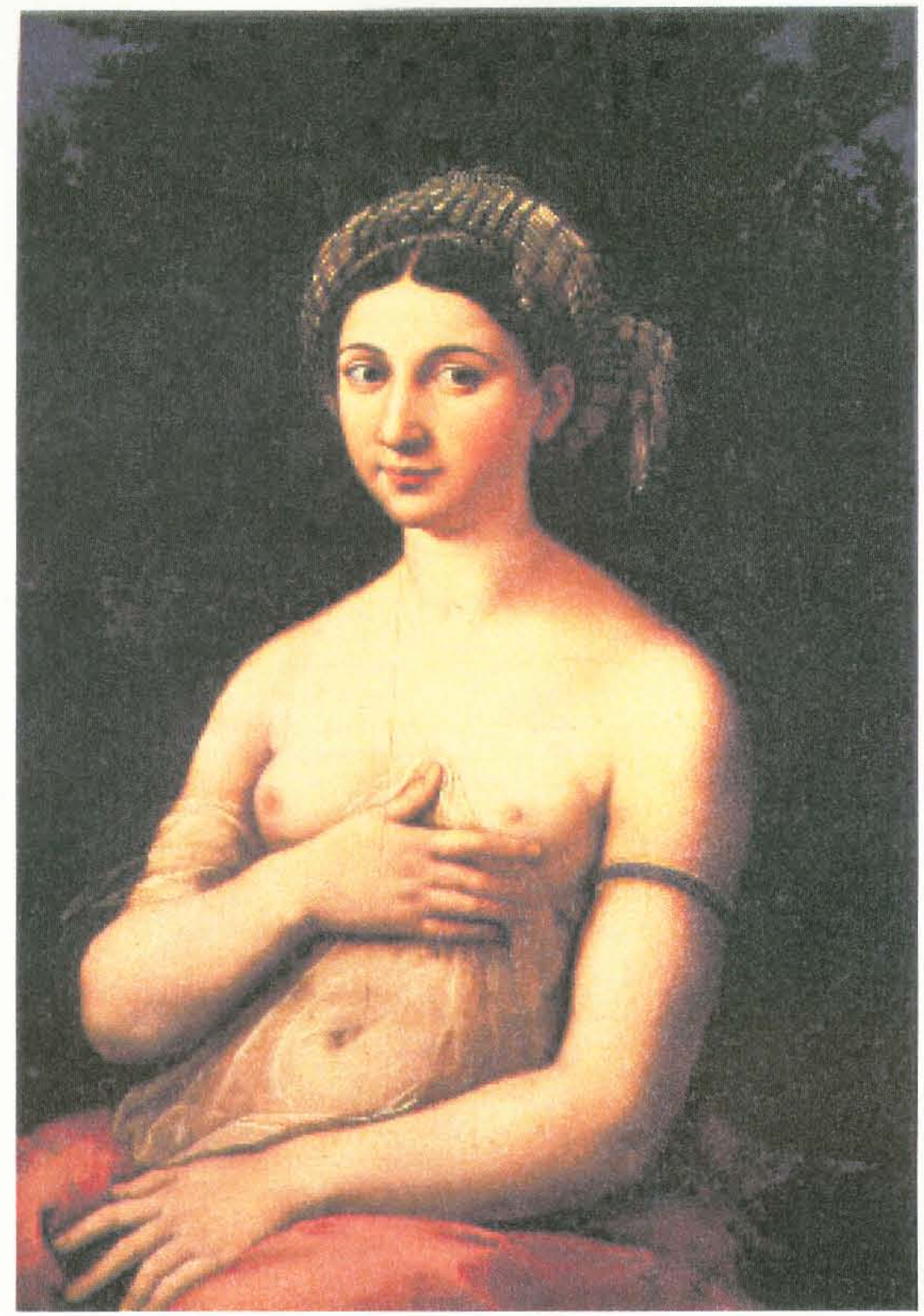

Figure 23. Raphael. La Fornarina, c. 1515. Oil on canvas, 34" x 25.5". Palazzo Barbarini, Rome.

Photograph from Lynn Lawner's book Lives of the Courtesans, p 2. 


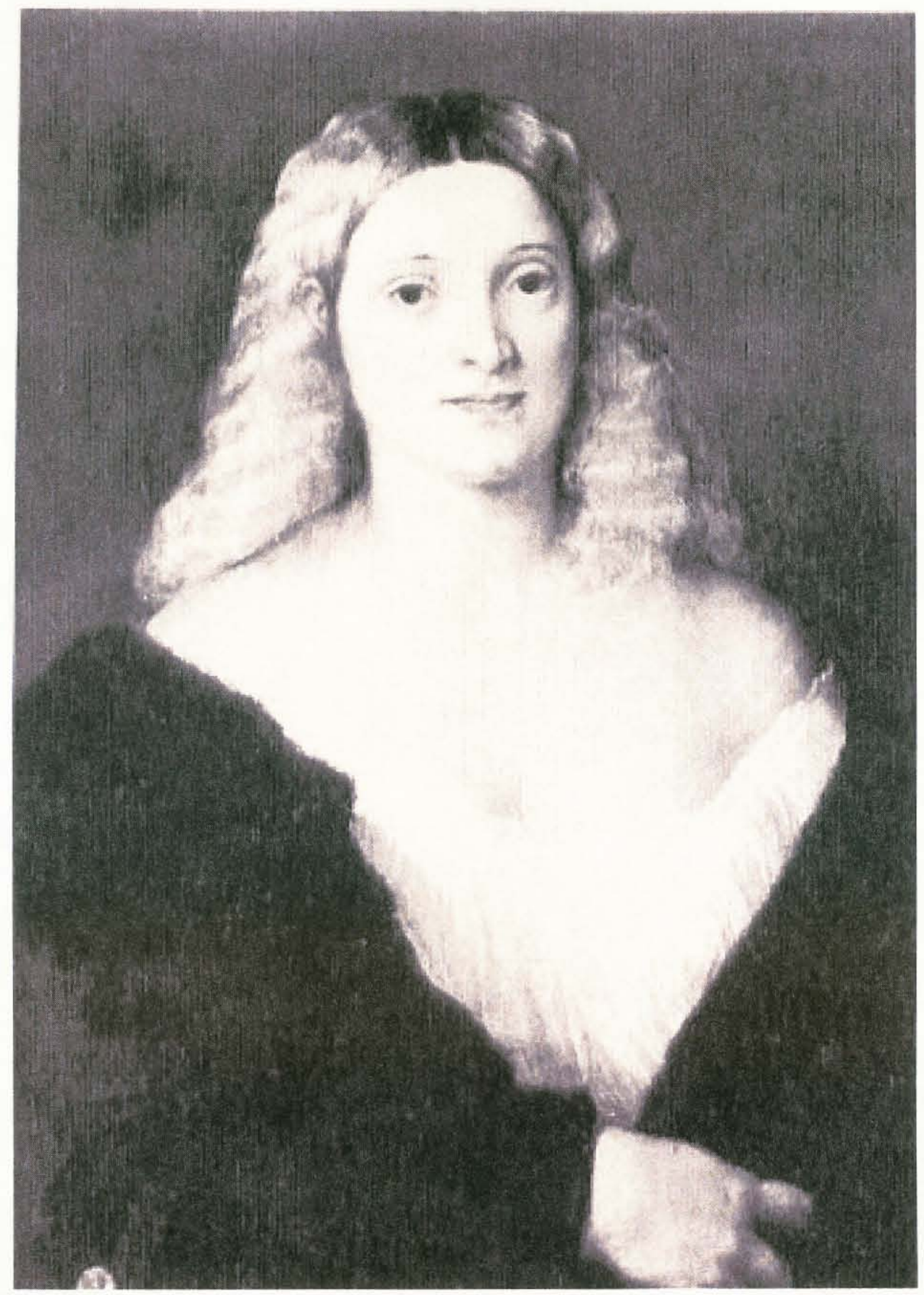

Figure 24. Palma Vecchio(Titian). Portrait of a Woman in Black, 1510. Oil on panel, $59.5 \times 44.5 \mathrm{~cm}$. Kunsthistorisches Museum, Vienna.

Photograph from Philip Ryland's book Palma Vecchio, p. 311. 


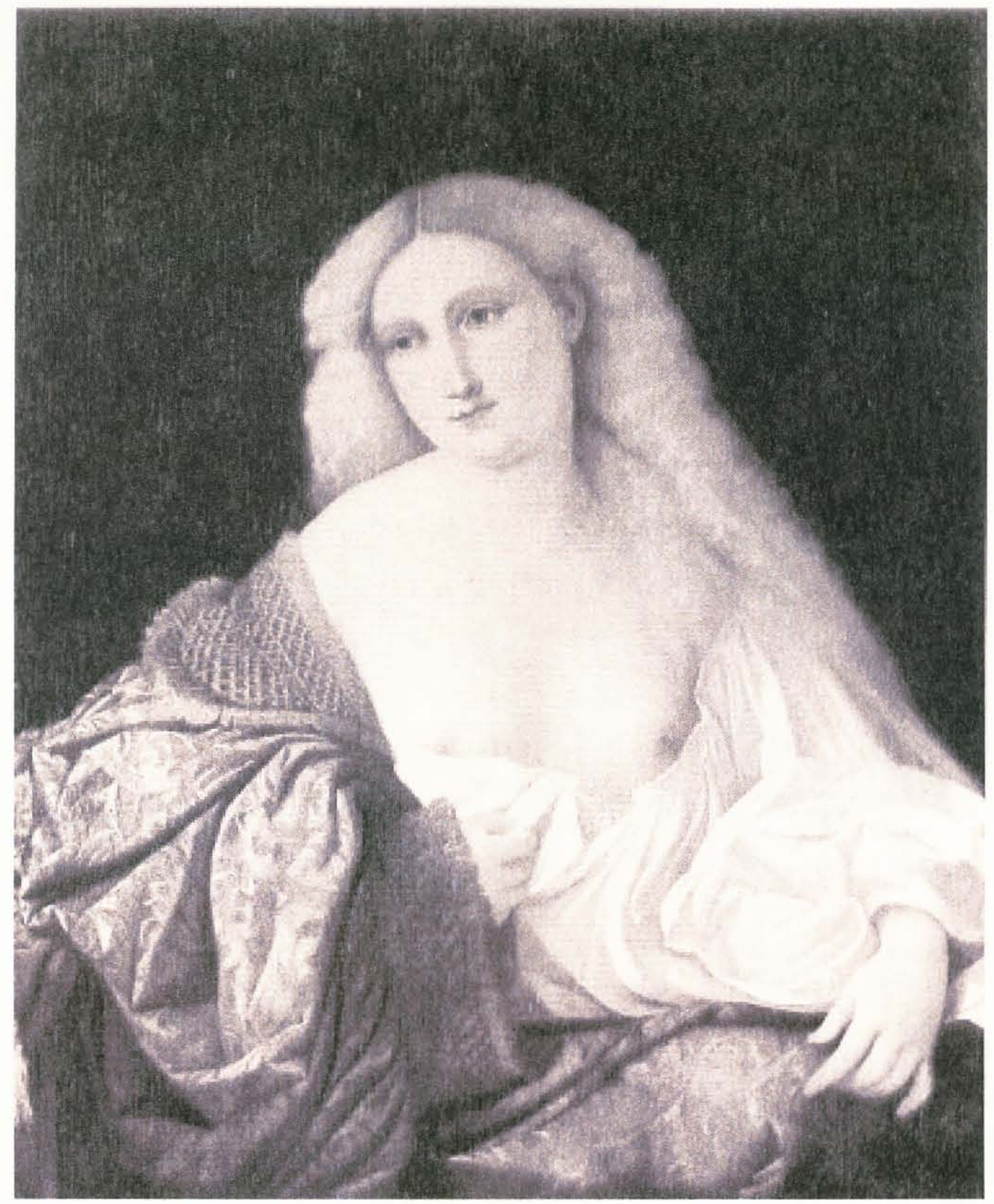

Figure 25. Palma Vecchio. Portrait of a Woman Called 'La Cortigiana', 1524-26. Oil on canvas, 87.4 x $73.5 \mathrm{~cm}$. Museo Poldi-Pezzoli, Madrid

Photograph from Philip Ryland's book Palma Vecchio, p. 221. 


\section{REFERENCES}

Adams, Laurie Schneider, "Iconographic Aspects of the Gaze in Some Paintings by Titan", The Cambridge Companion to Titian. Cambridge: Cambridge University Press, 2004.

Alberti, Leon Battista, On Painting and On Sculpture: The Latim Texts of De Picura and De Statua. Edited and Translation by Cecil Grayson, London: Phaidon, 1972.

Anderson, Jaynie, "Giorgione, Titian and the Sleeping Venus", Tiziano e Venezia; Convegno Internazionale di Studi. Venice: Neri Pozza Editore, 1976.

Berger, Henry, "Fictions of the Pose: Facing the Gaze of Early Modern Portraiture", Representations. 46, 1994.

Blanchard, H.H.,, Prose and Poetry of the Continental Renaissance in Translation. New York: Longman's, Green, \& Co., 1949.

Brock, Maurice, Bronzino. Flammarion, 2002.

Burkhardt, Jacob, The Civilization of the Renaissance in Italy. London: Middlemore, 1960.

Brown, Patricia Fortini, Art and life in Renaissance Venice. New York: Harry $\mathrm{N}$. Abrams Publishing, 1997.

Campbell, Lorne, Renaissance Portraits: European Portrait-Painting in the $14 t h, 15 t h$, and 16ih Centuries. New Haven: Yale University Press, 1990.

Capella, G.F., Della Eccellenza et Dignita della Donne. Venice, 1527.

Castiglione, Baldesar, The Book of the Courtier. New York: Daniel Javitich, ed., W.W. Norton \& Company, 2002.

Chojnacki, Stanley, Women and Men in Renaissance Venice: Twelve Essays on Patrician Society. Baltimore: Johns Hopkins University, 2000. 
Coryat, Thomas, Coryat's Crudities. Scolar Press, 1978.

Cranston, Jodi, The Poetics of Portraiture on the Italian Renaisance. Cambridge: Cambridge University Press, 2000.

Cropper, Elizabeth, "The Beauty of Woman: Probiems in the Rhetoric of Renaissance Portraiture", Rewriting the Renaissance;Discourses of Sexual Differences in Early Modern Europe. Chicago: University of Chicago Press, 1986.

Cropper, Elizabeth, "On Beautiful Women Parmagianino, Petrachisma and the Vernacular Style", Art Bulletin, 1976.

da Vinci, Leonardo, Leonardo on Painting, an Anthology of Writings by Leonardo da Vinci With a Selection of Documents Relating to His Career as an Artist. Martin Kemp, ed., New Haven: Yale University Press, 1989.

Fehl, Philipp P., Deconum and Wit: The Poetry of Venetian Paining. Vienna: IRSA. 1992.

Fermor, Sharon, "Poetry in Motion: Beauty in Movement and the Renaissance", Concepts of Beauty in Renaissance Art. Ashgate, 1998.

Fiero, Gloria, The Humanist Tradition From Romanticism in the Western World. Dubuque, IA: William C. Brown Communications, 1992

Firenzuola, Agnolo, On the Beauty of Women. Translated and edited by Konrad Eisenbichler \& Jacqueline Murray, Philadelphia: University of Pennsylvania Press, 1992.

Franco, Veronica, Poems and Selected Letters. Ann Rosalind Jone \& Margaret $\mathrm{F}$. Rosenthal, editors and translators, Chicago: University of Chicago, 1998.

Freedman, Luba, Titian 's Portrats Through Aretino's Lens. University Park, PA: Pennsylvania State Press, 1995.

Gambara, Veronica, The Defium Muse: Italian Feminist Poets from the Middle Ages wo the Present. New York: Allen, Kittel, \& Jewell, eds., 1986.

Garrard, Mary D., "Leonardo da Vinci: Female Portraits, Female Nature", The Expanding Discourse: Feminism \& Art History. N. Broude \& M.D. Garrard, ed., New York: Icon Editions, 1992. 
Goffen, Rona, Titian's Women. New Haven: Yale University Press, 1997.

Goodman-Soellner, E.: "Poetic Interpretations of the Lady at Her Toilette", Sixteenth Century Journal, 14, 1983.

Hartt, F., History of Italian REnaissance Art: Painting, Sculpture, Architecture. New York: Prentice Hall \& Abrams, 1994.

Held, J.S., "Flora, Goddess and Courtesan", Essays in Honor of Enwin Panofsky. Millard Meiss, ed, vol. I, New York: New York University Press, 1961.

Hennessey, John Pope, The Portrait in the Renaissance, The A.W.. Mellon Lecture in the Fine Arts. Washington, D.C.: National Gallery of Art, 1963.

Hirst, M., Sebastiano del Piombo. Oxford: Claredon Press, 1981.

Hope, Charles, "Problems of Interpretation in Titian's Erotic Paintings", Tiziuno e Venezia; Convegno Internazionale di Studi. Venice: Neri Pozza Editore, 1976.

Humphrey, Peter, Painting in Renaissance Venice. New Haven Yale University Press, 1995.

Kahr, Madlyn Milner, "Danae: Virtuous, Voluptuous, Venal Woman”, Arı Bulletin, 60, 1978.

Kelso, Ruth, Doctrine for the Lady of the Renaissance. Chicago: University of Illinois Press, 1978.

King, Margaret L., Women of the Renaissance. Chicago: University of Chicago Press, 1991.

Kleiner, R., Mamiya, C., Tansey, R., Gardner's Art Through the Ages, the Western Perspective, Ilthedition. U.S.A.: Thomas Wadsworth, 2003.

Labalme, Patricia H., "Women's Roles in Early Modern Venice: An Exceptional Case", Beyond Their Sex: Learned Women of the European Past. Patricia H. Labalme, ed., New York: New York University Press, 1980.

Land, Norman E., The Viewer As Poet: the Renassance Response to Art. University Park, PA: Pennsylvania State University Press, 1994. 
Lawner, Lynne, Lives of the Courtesans: Portraits of the Renaissance. New York, 1987.

Lomazzo, G.P., Scritii sulll'arte, ed R.P. Florence: Ciardi, Marchi \& Bertolli, 1973.

McClure, Laura K., Courtesans At Table: Gender and Greek Literary Culture in Athenaeus. New York: Routledge, 2003.

Mandel, C., "(Jacopo) [Giancomo] Palma (il) Vecchio", The Grove Dictionary of Art Online, Oxford University Press, Accessed March 30, 2004, <http://www.groveart.com>

Mason, G. ,Courtesans of the Italian Renaissance, London, 1985

Mellencamp, F.H.,, "A Note on the Costume of Titian's Flora", Art Bulletin. c. 51, June 1969.

Morford, Mark P.O. \& Lenardon, Robert J., Classical Mythology, 3rd Edition. White Plains, NY: Longman, 1985.

Norwich, John Julius, A History of Venice. New York: Vintage Books, 1989.

Petrarch, Francesco, For love of laura: Poetry of Petrarch. Marion Shore, translator, Fayetteville, AK: University of Arkansas Press, 1987.

Philostratus the Younger, Imagines (L.C.L.), trans. Arthur Fairbanks, 1947.

Pignatti, Terisio, The Golden Century of Venetian Painting. Los Angeles: Los Angeles County Museum of Art, 1979.

Pliny the Elder, Natural History. English Translation by H. Rackham, Cambridge: Cambridge University Press, 1949.

Pona, F., La Lucerna. Salerno, Roma, 1973.

Price, Paola Malpezzi, Moderata Fonte; Women and Life in Sixteenth-Century Venice. Madison Teaneck, London, 2003.

Richter, Jean Paul, ed., The literary Works of Leonardo da Vinci. Phaidon, London, 1970.

Rogers, Mary, "Fashioning Identities For the Renaissance Courtesan", Fashoming Identties in Renaissance Art. Mary Rogers, ed., Ashgate, 2000.

Rogers, Mary, "Reading the Female Body in Venetian Renaissance Art", New 
Interpretations of Venetian Renaissance Painting. E. Sussex: Caldra House, 1994.

Rogers, Mary, "Sonnets on Female Portraits From Renaissance North Italy", Word \& Image. 2, no. 4, October-December, 1986.

Rogers, Mary, "The Decorum of Women's Beauty: Trissino, Firenzuola, Luigini and the Representation of Women in Sixteenth-Century Painting", Renaissance Studies, 2 , no. 1 ,

Rosand, David, Painting in Sixteenth-Century Venice; Titian, Veronese, Tintoretto. Cambridge: Cambridge University Press, 1997.

Rosenthal, Margaret F., The Honest Courtesan, Veronica Franco, Citizen and Writer in Sixteenth-Century Venice. Chicago: University of Chicago Press, 1992.

Rylands, Philip, Palma Veccho. Cambridge: Cambridge University Press, 1992.

Santore, C., "Danae: The Renaissance Courtesan's Alter Ego," Zeitschrift fur Kunsigeschichle, 54, 1991.

Simons, Patricia, "Women in Frames: The Gaze, the Eye, the Profile in Renaissance Portraiture", The Fxpanding Discourse: Feminism and Art History. N. Broude \& M.D. Garrard, ed., New York: Icon Editions, 1992.

Sperling, Jutta Gisela, Convents and the Body Politic in Late Renaissance Venice. Chicago: University of Chicago Press, 1999.

Tinagli, Paola, Women in Iialian Renaissance Art: Gender, Representation, Identity. New York: Manchester University Press, 1997.

Vaccaro, Mary, "Beauty and Identity in Parmigianino's Portraits", Fashioning Identities in Renaissance Art. Ashgate, 2000.

Vasari, Giorgio, Le Opere di Giorgio Vasari /con nuove annotazione e commenti di Gaetano Milanesi]. Firenze: G.C. Sansoni.

Vasari, Giorgio, The Lives of the Artists, a new translation by Julia Conaway Bondanella \& Peler Bondanella, Oxford: Oxford University Press, 1991.

Virtue and Beauty: Leonardo's Ginevra de'Benci and Renaissance Portraits of Women. David Alan Brown, ed., Wahsington, D.C.: National Gallery of Art, Washington, D.C., 2001. 
Whitfield, J.H., Petrarch and the Renaissance. New York: Russell \& Russell, 1965. 


\section{CURRICULUM VITAE}

NAME: $\quad$ Sarah Elizabeth Fruehling

ADDRESS: $\quad 263$ Pennsylvania Ave. Louisville, KY 40206

DOB: $\quad$ August 16, 1977, Bucyrus, Ohio

EDUCATION: B.A., Art \& Family Consumer Sciences

Mount Vernon Nazarene College, Mount Vernon, $\mathrm{OH}$ 1995-2000 